\title{
Energetic Particle Precipitation and the Chemistry of the Mesosphere/Lower Thermosphere
}

\author{
M. Sinnhuber $\cdot$ H. Nieder $\cdot$ N. Wieters
}

Received: 28 February 2012/ Accepted: 23 August 2012/Published online: 27 November 2012

(C) The Author(s) 2012. This article is published with open access at Springerlink.com

\begin{abstract}
Precipitation of energetic particles into the atmosphere greatly disturbs the chemical composition from the upper stratosphere to the lower thermosphere. Most important are changes to the budget of atmospheric nitric oxides $\left(\mathrm{NOx}=\mathrm{N}, \mathrm{NO}, \mathrm{NO}_{2}\right)$ and to atmospheric reactive hydrogen oxides $\left(\mathrm{HOx}=\mathrm{H}, \mathrm{OH}, \mathrm{HO}_{2}\right)$, which both contribute to ozone loss in the stratosphere and mesosphere. The impact of energetic particle precipitation on the chemical composition of the atmosphere has been studied since the 1960s, and there are a number of observations as well as model studies concerning especially the auroral impact and large solar particle events. Changes to the NOx budget due to energetic particle precipitation can be quite long-lived during polar winter and can then be transported down into the lower mesosphere and stratosphere, where NOx is one of the main participants in catalytic ozone destruction. Energetic particle precipitation can also affect temperatures and dynamics of the atmosphere from the source region down to the stratosphere and possibly even down to the surface, due to a coupling of chemical composition changes affecting atmospheric heating and cooling rates, the mean circulation, and wave propagation and breaking. Thus, energetic particle precipitation impacts have been implemented in chemistry-climate models reaching from the surface up to the mesosphere or lower thermosphere. However, there are still a number of open questions in the theoretical description of the energetic particle precipitation impact; the most important are uncertainties in the formation rate of different NOx species due to energetic particle precipitation, and the complex coupling between chemical changes, atmospheric heating and cooling rates, and atmospheric dynamics.
\end{abstract}

Keywords Energetic particle precipitation - MLT region - Atmospheric chemistry · Solar-terrestrial coupling

M. Sinnhuber $(\bowtie) \cdot$ H. Nieder

Institute for Meteorology and Climate Research, Karlsruhe Institute of Technology, KIT Campus

North, Hermann von Helmholtz-Platz 1, 76344 Eggenstein-Leopoldshafen, Germany

e-mail: miriam.sinnhuber@kit.edu

URL: www.imk-asf.kit.edu

N. Wieters

Institute for Environmental Physics, University of Bremen, Bremen, Germany 


\section{Introduction}

Energetic particles-protons, electrons, and heavier ions- that precipitate into the atmosphere come from different sources: directly from the Sun in large solar particle events (SPEs), from the aurora and the radiation belts during geomagnetic storms and substorms, or from outside the solar system. The particles from these various sources have different energy spectra and interact differently with the terrestrial magnetic field; therefore, they affect different altitudes and geographic regions.

Solar particles come from the solar wind, a continuous source of plasma outflow from the solar polar regions or solar coronal holes modulated in strength (e.g., in solar wind speed or solar wind pressure) throughout the solar cycle, or from large eruptions in the solar atmosphere related to high solar activity, so-called solar coronal mass ejections. Solar coronal mass ejections are more frequent during the maximum of the 11-year solar cycle than during the minimum, while high-speed solar wind from coronal holes is more pronounced during the transition phase from solar maximum to solar minimum. The solar wind can be further accelerated in co-rotating interaction regions, but is mostly deflected by the Earth's magnetic field and does not precipitate into the terrestrial atmosphere directly. However, solar wind particles can couple into the terrestrial magnetosphere in the magnetotail region, forming the source of the aurora, or being trapped into the outer radiation belt; and high-speed solar wind from coronal holes, co-rotating interaction regions, or solar coronal mass ejections, is the source of disturbances of the geomagnetic field. More detailed information about solar sources of energetic particles and their progressing and further acceleration in the interplanetary magnetic field can be found, for example, in Reames (1999), Zhang et al. (2007), Gopalswamy (2008), and Richardson and Cane (2010). Coupling of energetic particles into the Earth's magnetosphere is described, for example, in Russell (2000) and Tsurutani et al. (2006).

High geomagnetic activity that is observed as deviations of the surface magnetic field from a mean state, the basis of the geomagnetic Kp and Ap indices (see, e.g., Mayaud 1980), is associated with high auroral activity, that is, enhanced precipitation of auroral electrons and protons. Auroral electrons are accelerated to energies of $1-10 \mathrm{keV}$, sufficient to precipitate into the uppermost mesosphere and lower thermosphere, to altitudes of $\sim 80-130 \mathrm{~km}$ (see, e.g., Fang et al. 2008). Auroral particles precipitate into the atmosphere at high latitudes, with largest fluxes occurring in the auroral-oval region $\left(\sim 65^{\circ}\right.$ geomagnetic latitude), but precipitation over the entire polar cap is also possible. During geomagnetic storms, the auroral oval can expand considerably and then extends to lower latitudes. As high geomagnetic activity is related both to coronal holes and to solar coronal mass ejections, geomagnetic activity can be enhanced both during solar maximum and during the transition to the solar minimum and has its minimum during the minimum phase of the 11-year solar cycle (see Fig. 1).

In geomagnetic storms, electrons in the radiation belts can be accelerated to relativistic energies from several tens of $\mathrm{keV}$ to several $\mathrm{MeV}$, sufficient to precipitate into the mesosphere and even upper stratosphere; these relativistic electrons are lost from the radiation belts again either by drifting out of the radiation belts into the interplanetary field or by precipitating down into the atmosphere, to geomagnetic latitudes connecting to the radiation belts, that is, from $\sim 55^{\circ}$ to $65^{\circ}$ (Horne et al. 2009). These are called relativistic electron precipitation events or energetic electron precipitation events. The acceleration and precipitation of radiation-belt particles during geomagnetic storms is not yet well understood, but involves scattering of the particles by different kinds of plasma waves (Millan and Thorne 2007). Relativistic radiation-belt electrons are associated with high- 

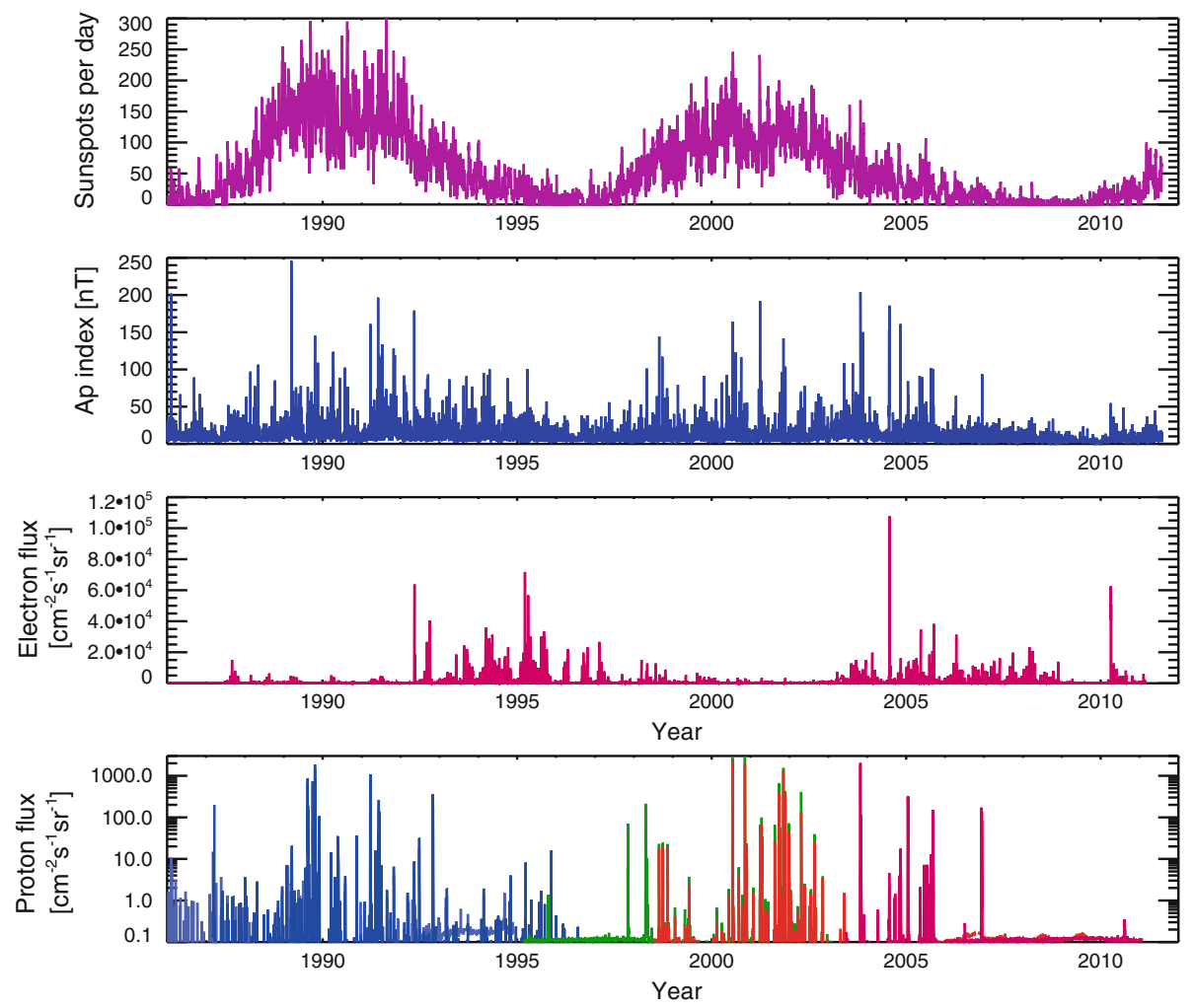

Fig. 1 Different indices for solar activity and energetic particle precipitation throughout the last 2 1/4 solar cycles. From top to bottom sunspot number per day, a proxy for solar activity; the Ap index, a proxy for geomagnetic activity linked to the precipitation of auroral particles; fluxes of relativistic electrons of energies $>2 \mathrm{MeV}$ in the radiation belts, merged data set using different GOES satellites; and fluxes of protons of energies $>50 \mathrm{MeV}$ as observed by particle counters onboard different GOES satellites (light blue GOES-6; dark blue GOES-7; green GOES-8; light red GOES-10; dark red GOES-11). Data are from the National Geophysical Data Center (http://www.ngdc.noaa.gov)

speed solar wind streams (Baker et al. 1993) and are most frequent during the transition phase from solar maximum to solar minimum (see also Fig. 1).

In solar coronal mass ejections, huge plasma clouds are ejected into space which may lead to greatly enhanced particle fluxes around Earth. In these plasma clouds, protons may be accelerated to energies of tens to hundreds of $\mathrm{MeV}$, sufficient to precipitate down into the mesosphere and upper stratosphere. These events are therefore also called Solar Proton Events or SPEs. Solar particles can precipitate into the atmosphere in the polar cap regions poleward of $\sim 60^{\circ}$ geomagnetic latitude, where the geomagnetic field couples to the interplanetary magnetic field. During large SPEs, the polar caps can expand considerably and then reach further into mid-latitudes. Figure 1 shows proton fluxes of protons with energies $>50 \mathrm{MeV}$ observed in geostationary orbit around Earth; events with increases of the proton flux over several orders of magnitude are related to solar coronal mass ejections or solar flares (Cane et al. 2003) and are observed more frequently during solar maximum than during solar minimum. 
Galactic cosmic rays (GCR) come from outside the solar system; they are composed mostly of protons with energies ranging from several $100 \mathrm{MeV}$ far into the $\mathrm{EeV}$ range, though the particle fluxes decrease strongly with energy, from about $10^{4} \mathrm{~m}^{-2} \mathrm{~s}^{-1}$ at $1,000 \mathrm{MeV}$ to $\sim 1 \mathrm{~km}^{-2}$ year $^{-1}$ at $1 \mathrm{EeV}^{1}$ (e.g., Anchordoqui et al. 2002; Schüssler et al. 2010). As the particle energies are so high, they are hardly affected by the Earth's magnetic field and precipitate into the atmosphere everywhere, reaching the lower stratosphere or troposphere down to the surface. The mesosphere and lower thermosphere region (MLT) is not affected by GCRs because their flux is too low; secondary particle showers, which provide large fluxes, form at lower altitudes.

In the second half of the last century, the chemical composition of the upper part of the atmosphere (the stratosphere, mesosphere, and lower thermosphere) came into the focus of research, and the chemical composition of the middle atmosphere and thermosphere was investigated using in situ instruments such as mass spectrometers on sounding rockets or remote sensing instruments on board sounding rockets, the space shuttles, or satellites. It soon became apparent that energetic particle precipitation can affect the chemical composition of the atmosphere above the tropopause quite significantly (e.g., Nicolet 1965, 1975; Weeks et al. 1972; Swider and Keneshea 1973; Crutzen 1975).

At low latitudes roughly equatorwards of $\sim 50^{\circ}$, NO in the lower thermosphere is thought to be formed by solar X-rays ionising the atmosphere around 100-120 km (e.g., Barth et al. 1988, 1999, 2003). The strong increase of NO in the lower thermosphere from low to high latitudes with high-latitude values being typically several times larger than low-latitude values (e.g., Rusch and Barth 1975; Cravens and Stewart 1978; Cravens et al. 1985; Fesen et al. 1990; Siskind et al. 1998) led to the conclusion that energetic particle precipitation within the aurora is a major source of NO in the lower thermosphere, with peak altitudes in the region around 105-110 km (Cravens et al. 1985; Fesen et al. 1990; Barth et al. 2003; Saetre et al. 2004). High values of NO have been observed directly within the aurora (Zipf et al. 1970) or during or shortly after high geomagnetic activity or particle precipitation events at high latitudes (Gerard and Barth 1977; Iwagami and Ogawa 1980; Grossmann et al. 1985; Crowley et al. 1998), and a correlation between NO in the lower thermosphere at high latitudes and energetic particle fluxes (e.g., Baker et al. 2001, 2003) or geomagnetic activity (e.g., Solomon et al. 1999; Marsh et al. 2004; Sinnhuber et al. 2011) is now well established. Though thermospheric NO is also very variable at high latitudes due to the small-scale structure and temporal variability of the aurora (e.g., Cravens and Stewart 1978; Barth et al. 2003), on average, a broad auroral-oval-like structure is clearly visible in NO in the lower thermosphere (e.g., Barth et al. 2001, 2003; see also Panels A and C of Fig. 2) because of the lifetime of NO of several days at these altitudes (this is also discussed in Sect. 2.2.3). A trade-off between production rates and lifetimes is probably also the reason for a time lag of $\sim 1$ day between the geomagnetic forcing as indicated by the Kp index, and the NO response (e.g., Solomon et al. 1999).

In the middle atmosphere, strong losses of ozone have been observed correlated to most of the large SPEs of the last $\sim 43$ years in the upper stratosphere and mesosphere, for example in November 1969 (Weeks et al. 1972), August 1972 (Heath et al. 1977), during several smaller SPEs between 1979 and 1982 (McPeters and Jackman 1985), and during several of the very large SPEs of the last solar maximum (e.g., Jackman et al. 2001, 2005a; Rohen et al. 2005; Storini and Damiani 2007; Damiani et al. 2010; Funke et al. 2011; and Jackman et al. 2011). In the mesosphere, ozone losses directly during very large SPEs can exceed $70 \%$ within 1 day (e.g., Jackman et al. 2001).

$1 \mathrm{EeV}$ is $10^{18} \mathrm{eV}$ 
A
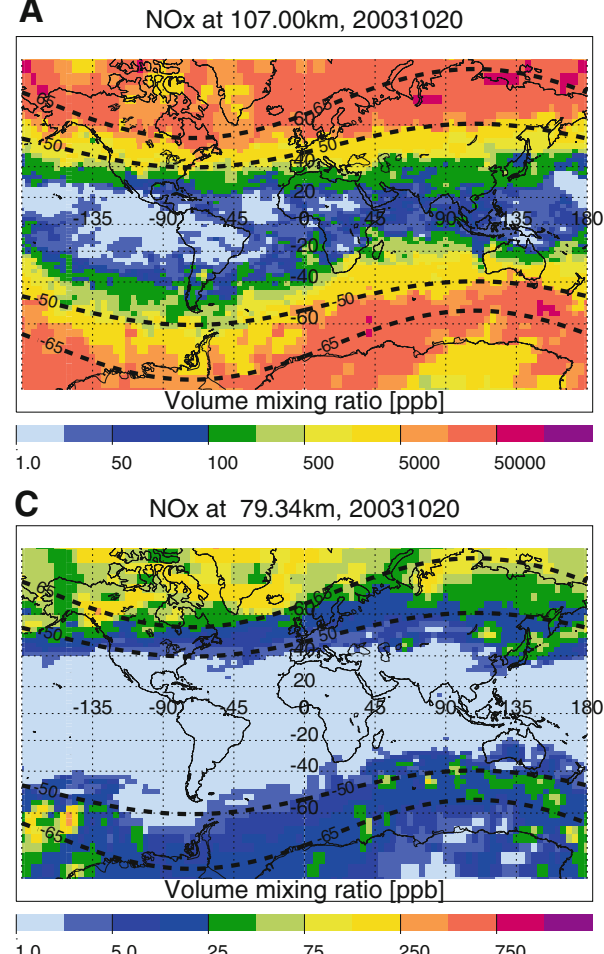

B NOx at $107.29 \mathrm{~km}, 20031030$

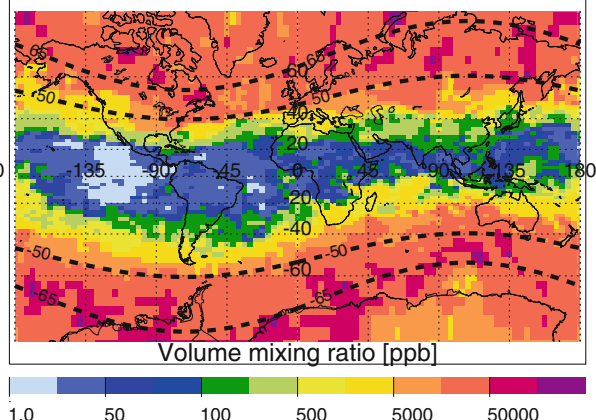

D NOx at $79.38 \mathrm{~km}, 20031030$

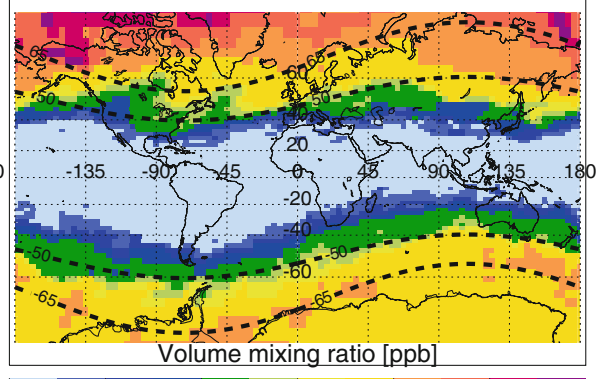

\begin{tabular}{lll|l|l|l|l}
\hline & & & & & $\mid$ \\
1.0 & 5.0 & 25 & 75 & 250 & 750
\end{tabular}

Fig. 2 Coloured contours $\mathrm{NOx}\left(\mathrm{NO}+\mathrm{NO}_{2}\right.$, ppb) modelled with a three-dimensional chemistry and transport model (CTM) which considers energetic particle precipitation (see "Appendix 1") for 2 days in October 2003. A, C 20 October 2003, a geomagnetically quiet day; B, D 30 October 2003, during a large solar particle event. A, B $\sim 107 \mathrm{~km}$, that is, within the aurora region; $\mathbf{C}, \mathbf{D} \sim 79 \mathrm{~km}$, upper mesosphere at the lower edge of the auroral region. Shown is the relative difference to a model run without atmospheric ionisation. Dashed lines isolines of geomagnetic latitude, marking $58^{\circ}$ and $68^{\circ}$ of geomagnetic latitude, that is, roughly the position of the auroral oval. On the quiet day, the auroral oval is clearly visible in the lower thermosphere and upper mesosphere NOx in the Southern summer hemisphere; during polar winter, the lifetime of NOx is longer, and the auroral signature is therefore masked by horizontal transport, and not as clearly visible. During the solar event, the whole polar cap region polewards of $60^{\circ}$ geomagnetic latitude is affected down to the upper stratosphere. Atmospheric ionisation due to energetic particles is considered here using the three-dimensional time-resolved Atmospheric Ionization Model OSnabrück (AIMOS), which scales to polar cap size and auroral-oval size and position by geomagnetic local time and geomagnetic activity depending on the incident particles energy and species (Wissing and Kallenrode 2009)

It has been argued by Crutzen (1975) that large SPEs should be a source of nitric oxide in the stratosphere, and large enhancements of several orders of magnitude of $\mathrm{NO}$ and $\mathrm{NO}_{2}$ have also been observed during several large SPEs, showing increases of more than $50 \mathrm{ppb}$ in the altitude range $\sim 40-80 \mathrm{~km}$, compared to a background value of less than $10 \mathrm{ppb}$ in this altitude region (e.g., Jackman et al. 2001, 2005a; Lopez-Puertas et al. 2005a, 2006; Funke et al. 2011; Jackman et al. 2011). As during SPEs, the energetic particles can precipitate over the complete polar cap, both the ozone loss and the increase of NOx related to the particle event occur over the complete polar cap area (e.g., Jackman et al. 2001; Funke et al. 2011; see also Panel B and D of Fig. 2).

The large ozone losses observed during SPEs at high latitudes have been attributed to positive ion-chemistry reactions transferring $\mathrm{H}_{2} \mathrm{O}$ into $\mathrm{HOx}$ (Swider and Keneshea 1973; 
Solomon et al. 1981). However, $\mathrm{HOx}$ species $\left(\mathrm{OH}, \mathrm{HO}_{2}, \mathrm{H}_{2} \mathrm{O}_{2}\right)$ have only been observed globally in the last decade; since then, increases in mesospheric $\mathrm{OH}$ have been observed both during large SPEs (e.g., Storini and Damiani 2007; Damiani et al. 2010; Jackman et al. 2011) and correlated to energetic electron precipitation events (e.g., Verronen et al. 2011a; Andersson et al. 2012); an increase in stratospheric $\mathrm{H}_{2} \mathrm{O}_{2}$ has been observed during two large SPEs (Funke et al. 2011; Jackman et al. 2011), and an increase in $\mathrm{HO}_{2}$ during one large solar particle event (Jackman et al. 2011). Indirect evidence for an increase in HOx in the stratosphere has also been derived from increases in $\mathrm{HOCl}$ during the large solar event of October/November 2003 (von Clarmann et al. 2005).

The good coverage of a number of trace gases with remote sensing observations from space in the middle atmosphere in the last decade has made the discoveries of new chemical processes due to energetic particle precipitation possible, showing, for example, enhancements of $\mathrm{N}_{2} \mathrm{O}$ (Funke et al. 2008a, b; Semeniuk et al. 2008) and $\mathrm{HNO}_{3}$ (Kawa et al. 1995; de Zafra and Smyshlyaev 2001; Lopez-Puertas et al. 2005a; Stiller et al. 2005; Orsolini et al. 2005, 2009) correlated to geomagnetic activity and large solar events, or a decrease of $\mathrm{HCl}$ (Winkler et al. 2009, 2011) and increases in reactive chlorine (von Clarmann et al. 2005).

It has also been discussed in a number of publications whether precipitation of relativistic electrons from the radiation belt can have a large impact on the composition of the stratosphere and mesosphere comparable to SPEs (e.g., Baker et al. 1993; Callis et al. 1998a, b, 2001). Enhancements of NO have been observed during energetic electron precipitation events above $\sim 80 \mathrm{~km}$ (e.g., Callis et al. 1998a; Crowley et al. 1998) and around 70-85 km (Newnham et al. 2011). Evidence has also been given for a correlation between $\mathrm{OH}$ (Verronen et al. 2011a, Andersson et al. 2012) and NOx (Sinnhuber et al. 2011) to fluxes of precipitating relativistic electrons of $100-300 \mathrm{keV}$ in the altitude region around 70-90 km. However, while there is evidence for an impact of energetic electron precipitation to altitudes above $\sim 70 \mathrm{~km}$, it is difficult to find observational evidence for a similar impact to lower altitudes. Strong increases of NOx in the upper stratosphere and lower mesosphere around $\sim 60 \mathrm{~km}$ correlated to energetic electron precipitation (Renard et al. 2006) or down to $\sim 50 \mathrm{~km}$ correlated to relativistic radiation-belt electrons (Clilverd et al. 2009) have been reported for the Northern hemisphere in early 2004, but correlations with tracer data have shown that these observations are more likely due to downwelling of NOx from the lower thermosphere (e.g., Lopez-Puertas et al. 2006; Funke et al. 2007). An anti-correlation between ozone at high latitudes during polar winter was found in the midstratosphere $(\sim 32 \mathrm{~km})$ to the fluxes of relativistic electrons in the radiation belts (Sinnhuber et al. 2006), suggesting an impact of relativistic electron precipitation onto ozone in the mid-stratosphere, but the coupling mechanism is not quite clear. At the moment, the issue whether relativistic electrons can have a similar large impact on the stratosphere and mesosphere as large solar events is unresolved, but the observational evidence so far suggests that if relativistic electrons have an impact on the NOx budget of the middle atmosphere below $\sim 70 \mathrm{~km}$, it is small compared to either large solar events, or an indirect impact due to downwelling from the lower thermosphere.

In this paper, we will discuss the impact of energetic particle precipitation on the chemical composition of the mesosphere and lower thermosphere (the MLT region), and its coupling to the atmosphere below and atmospheric dynamics. We will first explain the processes leading to chemical disturbances during energetic particle precipitation events in the MLT region in Sect. 2. Long-term impacts on the neutral chemistry of the MLT region and the coupling to the atmosphere below and atmospheric dynamics are discussed in Sect. 3. A summary of open questions is given in Sect. 4. To illustrate the concepts discussed, 
results from different numerical models of the atmospheric composition in the MLT region are used. The models are described in the "Appendix".

\section{Energetic Particles: Impact on the Composition of the MLT Region}

Energetic particle precipitation affects the chemical composition of the atmosphere due to a chain of processes starting with the primary interaction of the incident particles with matter, which can lead to excitation, dissociation, dissociative ionisation, or ionisation of the most abundant species. In the auroral region of the thermosphere, the primary excitation as well as the formation of excited states of $\mathrm{N}_{2}, \mathrm{O}_{2}, \mathrm{O}$ and their ions due to the dissociation and ionisation processes are the source of the auroral airglow; dissociation and ionisation also affect the neutral and ionic composition of the atmosphere, both in the middle atmosphere (stratosphere and mesosphere) and in the thermosphere.

In this section, the impact of particle precipitation on the composition of the MLT region will be discussed, both from the primary particle-air interaction, and from subsequent ion chemistry. In Sect. 2.1, the primary interaction processes are discussed, followed by the most important changes to the neutral atmosphere: the formation of NOx and Ox (Sect. 2.2) and HOx (Sect. 2.3) and subsequent ozone loss in the mesosphere (Sect. 2.4). In Sect. 2.5, several of the less well-known changes to the neutral atmosphere are discussed.

\subsection{Primary Processes}

Energetic particles precipitating into the atmosphere lose their energy by collision reactions with the most abundant species-in the MLT region $\mathrm{N}_{2}, \mathrm{O}_{2}$, and $\mathrm{O}$. In the upper thermosphere, $\mathrm{He}$ and $\mathrm{H}$ also contribute (e.g., Jones and Rees 1973); in the stratosphere, only $\mathrm{N}_{2}$ and $\mathrm{O}_{2}$ need to be considered (e.g., Porter et al. 1976; Rusch et al. 1981). The primary interactions leading to composition changes in the MLT region are dissociation and dissociative ionisation of $\mathrm{O}_{2}$ and $\mathrm{N}_{2}$ as well as ionisation of $\mathrm{O}_{2}, \mathrm{~N}_{2}$, and $\mathrm{O}$ :

$$
\begin{array}{cc}
\mathrm{O}_{2}+p \rightarrow \mathrm{O}+\mathrm{O}+p & (\mathrm{R}-1(\mathrm{a})) \\
\mathrm{N}_{2}+p \rightarrow \mathrm{N}+\mathrm{N}+p & (\mathrm{R}-1(\mathrm{~b})) \\
\mathrm{N}_{2}+p \rightarrow \mathrm{N}_{2}^{+}+p+e^{-} & (\mathrm{R}-1(\mathrm{c})) \\
\mathrm{O}_{2}+p \rightarrow \mathrm{O}_{2}^{+}+p+\mathrm{e}^{-} & (\mathrm{R}-1(\mathrm{~d})) \\
\mathrm{N}_{2}+p \rightarrow \mathrm{N}^{+}+\mathrm{N}+p+e^{-} & (\mathrm{R}-1(\mathrm{e})) \\
\mathrm{O}+p \rightarrow \mathrm{O}^{+}+p+e^{-} & (\mathrm{R}-1(\mathrm{f}))
\end{array}
$$

$p$ is the incident particle (primary proton, electron or ion, or secondary electron). All processes can form the excited states of the reactants as well, that is, excited states of $\mathrm{N}, \mathrm{O}$, $\mathrm{N}_{2}{ }^{+}, \mathrm{O}_{2}{ }^{+}, \mathrm{N}^{+}$, or $\mathrm{O}^{+}$(e.g., Jones and Rees 1973; Porter et al. 1976). Ionisation and dissociative ionisation also provide secondary electrons that can then interact with the ambient air in a similar way. This starts a cascade of collision reactions that last until the primary particles and all secondary electrons have reached the average kinetic energy of the ambient air.

The relative probability of one of the processes of $\mathrm{R}-1, P$, can be deduced considering its interaction cross section $\sigma$, the abundance of the target species, $[c]$, and the flux of 
interacting particles (primary and secondary), $\Psi . \sigma$ is dependent on the energy of the interacting particle (e.g., Kieffer and Dunn 1966; Porter et al. 1976; Majeed and Strickland 1997), so this relation has to be determined dependent on the energy of the interacting energetic particles, $E$.

$$
P_{i j}(E)=\frac{\sigma_{i j}(E)\left[c_{j}\right] \Psi(E)}{\sum_{k} \sigma_{\mathrm{tot}, k}(E)\left[c_{k}\right] \Psi(E)}=\frac{\sigma_{i j}(E)\left[c_{j}\right]}{\sum_{k} \sigma_{\mathrm{tot}, k}(E)\left[c_{k}\right]}
$$

$\Psi(E)$ is the total flux of energetic particles including secondary electrons of energy $E$; the flux of secondary electrons has to be calculated from the incident particle fluxes. The indices $j$ and $k$ relate to different targets, $i$ relate to different reaction pathways of $j$. This relation has been simplified in different ways to derive the relative probabilities of the different pathways independent of the incident particle energy and secondary electron distribution. Jones and Rees (1973) estimated the relative abundance of primary ions relative to the total ion pair production rate (IPR) in the form

$$
P\left(c^{+}\right)=\frac{\sigma_{\mathrm{c}}^{+}[C] \times \mathrm{IPR}}{1.15\left[\mathrm{~N}_{2}\right]+1.5\left[\mathrm{O}_{2}\right]+0.56[\mathrm{O}]+0.43[\mathrm{He}]+0.8[\mathrm{H}]}
$$

$P\left(c^{+}\right)$is the formation rate of an ion $\mathrm{c}^{+}\left(\mathrm{N}_{2}{ }^{+}, \mathrm{O}_{2}{ }^{+}, \mathrm{N}^{+}, \mathrm{O}^{+}, \mathrm{H}^{+}\right.$, or $\left.\mathrm{He}^{+}\right)$relative to the total IPR. $\sigma_{c}^{+}$is an estimate of the cross section of formation of $c^{+}$from the target species $C$, and $1.15,1.5,0.56,0.43$, and 0.8 are total reaction cross sections for $\mathrm{N}_{2}, \mathrm{O}_{2}, \mathrm{O}_{1} \mathrm{H}_{2}$, and $\mathrm{H}$ relative to the cross section of $\mathrm{O}_{2}{ }^{+}$formation. All cross sections are integrated over energy. The formation rate is a function of the IPR and the relative abundance of the most ambient species, which contribute to the atmospheric ionisation. In the MLT region between about 70 and $150 \mathrm{~km}$, these are $\mathrm{N}_{2}, \mathrm{O}_{2}$, and $\mathrm{O}$, and below about $70 \mathrm{~km}$, only $\mathrm{N}_{2}$ and $\mathrm{O}_{2}$ play a role. In the middle and upper thermosphere, $\mathrm{H}_{2}$ and $\mathrm{H}$ also need to be considered. In the stratosphere and mesosphere, dissociation of $\mathrm{N}_{2}$ and $\mathrm{O}_{2}$ also is an important process (see Porter et al. 1976; Rusch et al. 1981; also Sect. 2.2.1), which however need not be considered in the thermosphere (above $\sim 80-100 \mathrm{~km}$ ).

The forcing term, the IPR, is a function of the energy deposition of the precipitating particles; on average, about $35 \mathrm{eV}$ are needed to produce one ion pair in ambient air (e.g., Porter et al. 1976). Protons and heavier ions, because of their large mass, precipitate in a straight line, and a continuous energy loss model like a Bethe-Bloch model can be assumed to calculate the energy deposition rate as a function of atmospheric density and penetration depths. This is described, for example, in Vitt and Jackman (1996). Electrons, because of their lighter mass, are scattered and also produce Bremsstrahlung; they and their secondary particles do not precipitate in a straight line. This can best be reproduced by a Monte Carlo approach (e.g., Solomon 2001; Wissing and Kallenrode 2009), which however is very time consuming. Therefore, atmospheric ionisation due to electrons is often prescribed by simple empirical relationships based on geomagnetic indices or incident electron energies (e.g., Roble and Ridley 1987; Fang et al. 2008, 2010).

\subsection{Formation of NOx and Ox}

\subsubsection{Formation of $N$ and $O$ by Dissociation}

Rusch et al. (1981) calculated the production rates of $\mathrm{N}, \mathrm{N}^{+}, \mathrm{N}_{2}{ }^{+}, \mathrm{O}^{+}$, and $\mathrm{O}_{2}{ }^{+}$as a function of the IPR from dissociation, dissociative ionisation, and ionisation of $\mathrm{N}_{2}$ and dissociative ionisation and ionisation of $\mathrm{O}_{2}$ using relative cross sections for the 
homosphere. As the relative abundance of $\mathrm{N}_{2}$ and $\mathrm{O}_{2}$ is constant in the homosphere, the results only depend on the IPR:

$$
\begin{array}{rr}
P\left(\mathrm{~N}_{2}^{+}\right)=0.585 \times \mathrm{IPR} & (\mathrm{R}-4(\mathrm{a})) \\
P\left(\mathrm{~N}^{+}\right)=0.185 \times \mathrm{IPR} & (\mathrm{R}-4(\mathrm{~b})) \\
P\left(\mathrm{O}_{2}^{+}\right)=0.154 \times \mathrm{IPR} & (\mathrm{R}-4(\mathrm{c})) \\
P\left(\mathrm{O}^{+}\right)=0.076 \times \mathrm{IPR} & (\mathrm{R}-4(\mathrm{~d})) \\
P(\mathrm{~N})=(0.985-1.385) \times \mathrm{IPR} & (\mathrm{R}-4(\mathrm{e}))
\end{array}
$$

The uncertainties of $P(\mathrm{~N})$ reflect differing experimental values of the dissociation cross sections of $\mathrm{N}_{2}$ (Rusch et al. 1981).

Rusch et al. (1981) also considered the rate of formation of $\mathrm{N}$ due to subsequent ionchemistry reactions; this is discussed in Sect. 2.2.2.

A different approach was used by Porter et al. (1976), also for the homosphere; they explicitly calculated the formation of secondary electrons due to the different ionisation and dissociative ionisation pathways of $\mathrm{N}_{2}$ and $\mathrm{O}_{2}$ and derived the relative reaction probabilities for the different possible reaction pathways of $\mathrm{N}_{2}$ and $\mathrm{O}_{2}$ as a function of incident particle energy separately for protons and electrons. From this, they calculated the formation rates of neutral $\mathrm{N}$ and $\mathrm{O}$ as well as $\mathrm{N}^{+}$and $\mathrm{O}^{+}$ions a function of the IPR and of the incident particle energy. They found that the production rates due to electrons and protons converge to constant values for higher energies of the incident particles (above $\sim 150 \mathrm{eV}$ for electrons, above $\sim 500 \mathrm{eV}$ for protons); below these incident particle energies, the different branches of the production change rapidly. However, in the convergence range, the rates for incident protons and electrons are very similar. As the best estimate for the convergence range, $P(\mathrm{~N})=1.27 \mathrm{IPR}$ and $P(\mathrm{O})=1.15 \mathrm{IPR}$ are given. The $\mathrm{N}$ production is in good agreement with the value from Rusch et al. (1981) (see R-4(e)); as dissociation of $\mathrm{O}_{2}$ is not considered by Rusch et al. (1981), the formation of $\mathrm{O}$ is much lower than the value given by Porter et al. (1976). Porter et al. (1976) also calculated the production rates separately for the ground- and excited states of $\mathrm{N}$ and give a partitioning of the ground state $\left(\mathrm{N}\left({ }^{4} \mathrm{~S}\right)\right)$ to several excited and ionised states of $\mathrm{N}$ as 0.538:0.660, or $45 \%$ in the ground state and $55 \%$ in the different excited and ionised states.

The values of Porter et al. (1976) and Rusch et al. (1981) are widely used in models of the middle atmosphere to parameterise the production of $\mathrm{N}$ and $\mathrm{N}^{*}$ due to atmospheric ionisation (e.g., Jackman et al. 2005a; Sinnhuber et al. 2003; Rohen et al. 2005; Funke et al. 2011 and references therein). However, the estimate of primary ionisation of $\mathrm{N}_{2}{ }^{+}$, $\mathrm{O}_{2}{ }^{+}, \mathrm{O}^{+}$, and $\mathrm{N}^{+}$, as given by Rusch et al. (1981), is not valid in the MLT region, as direct ionisation of $\mathrm{O}$ has to be taken into account there. To illustrate this, in Fig. 3 is shown a comparison of the primary ionisation rate of $\mathrm{N}_{2}{ }^{+}, \mathrm{O}_{2}{ }^{+}, \mathrm{O}^{+}$, and $\mathrm{N}^{+}$as given by Rusch et al. (1981), compared to an extension including ionisation of atomic oxygen as a function of altitude in the range 40-140 km. The cross sections of Rusch et al. (1981) were used for $\mathrm{N}_{2}$ and $\mathrm{O}_{2}$; for $\mathrm{O}$, relative cross sections were derived from Jones and Rees (1973). As can be seen, the primary ionisation of $\mathrm{O}_{2}^{+}$and $\mathrm{O}^{+}$begins to differ from the Rusch et al. (1981) around $\sim 85 \mathrm{~km}$ altitude, that is, in the upper mesosphere; above $\sim 125 \mathrm{~km}$, formation of $\mathrm{O}^{+}$becomes more important than formation of $\mathrm{O}_{2}^{+}$. As the ionisation capacity of atomic oxygen is less effective than that of molecular oxygen, the total ionisation $Q=Q\left(\mathrm{~N}_{2}\right)+Q\left(\mathrm{O}_{2}\right)+Q(\mathrm{~N})+Q(\mathrm{O})$ decreases above $\sim 85 \mathrm{~km}$, and the relative 
Fig. 3 Primary ionisation rates per ion pair of $\mathrm{N}_{2}^{+}$(red), $\mathrm{N}^{+}$ (orange from dissociative ionisation of $\mathrm{N}_{2}$ ), $\mathrm{O}_{2}{ }^{+}$(dark blue), and $\mathrm{O}^{+}$(light blue, from dissociative ionisation of $\mathrm{O}_{2}$ and ionisation of $\mathrm{O})$. Solid lines based on R-3 using cross sections from Rees and Jones (1973) and Rusch et al. (1981). Dashed lines Rusch et al. (1981). Green line formation of $\mathrm{N}\left({ }^{4} \mathrm{~S}\right)$ respectively $\mathrm{N}\left({ }^{2} \mathrm{D}\right)$ based on the lower limit of Rusch et al. (1981) with equal partitioning between the groundand excited states

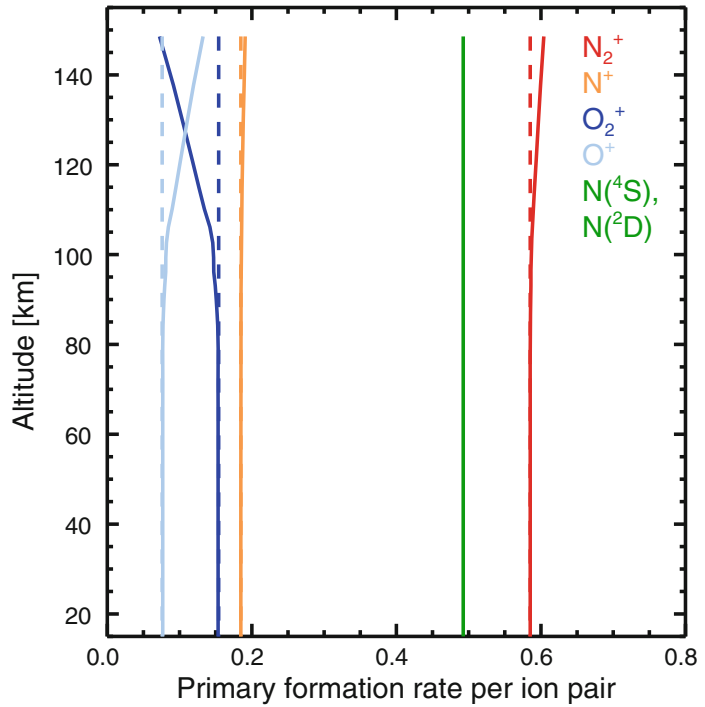

ionisation of $\mathrm{N}_{2}$ and $\mathrm{N}, Q\left(\mathrm{~N}_{2}\right) / Q$ and $Q(\mathrm{~N}) / Q$, increases compared to the constant values of Rusch et al. (1981) appropriate for the homosphere.

\subsubsection{Formation of NOx by Ion Chemistry}

The formation of the primary ions $\mathrm{N}_{2}{ }^{+}, \mathrm{O}_{2}{ }^{+}, \mathrm{O}^{+}$, and $\mathrm{N}^{+}$is the starting point of fast ionchemistry reactions which also can impact the neutral atmosphere quite considerably and also lead to the formation of $\mathrm{NOx}\left(\mathrm{N}, \mathrm{NO}, \mathrm{NO}_{2}\right)$. In the lower to mid-thermosphere, only the positive ions $\mathrm{N}^{+}, \mathrm{N}_{2}{ }^{+}, \mathrm{NO}^{+}, \mathrm{O}^{+}$, and $\mathrm{O}_{2}{ }^{+}$need to be considered (for a recent review of
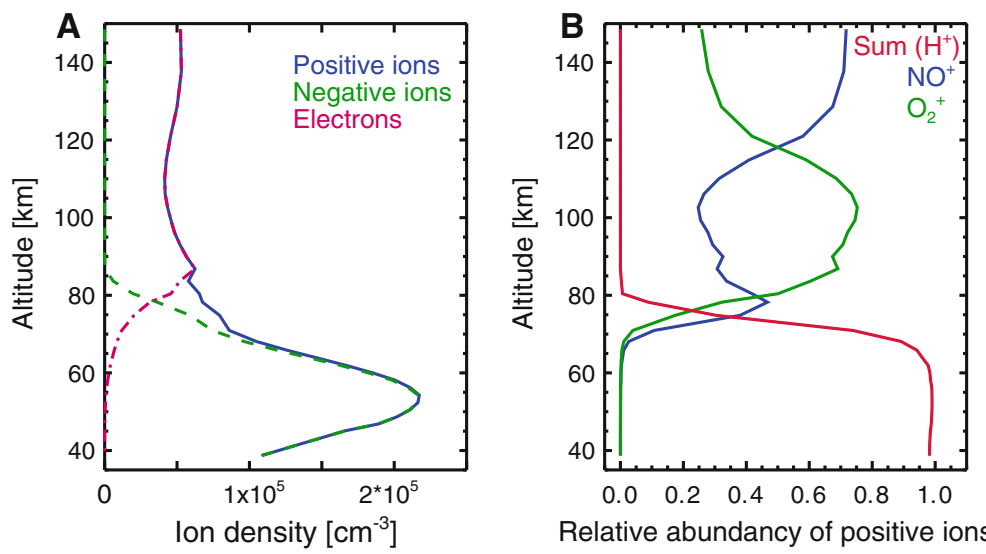

Fig. 4 Partitioning of ion species in the middle atmosphere and lower thermosphere. Result from the University of Bremen ion-chemistry model (UBIC, see "Appendix 2") for the time-period of the "Halloween" solar event, averaged from 28 October to 30 October 2003 at $70^{\circ} \mathrm{N} / 180^{\circ} \mathrm{E}$. A Number density $\left(\mathrm{cm}^{-3}\right.$ ) of positive ions (blue), negative ions (green), and electrons (blue). B The most abundant positive ions: the sum of all $\mathrm{H}^{+}$-cluster ions $\left(\mathrm{H}^{+}\left(\mathrm{H}_{2} \mathrm{O}\right) n\right.$, red), $\mathrm{NO}^{+}$(blue) and $\mathrm{O}_{2}{ }^{+}$(green) 
thermospheric ion chemistry, see Richards 2011). In the middle atmosphere, negative ions become more abundant than electrons below $\sim 75-85 \mathrm{~km}$ altitude (e.g., Fritzenwallner and Kopp 1998, see also Panel A of Fig. 4), and large water cluster ions become the most abundant positive ion species (e.g., Kopp et al. 1985, see also Panel B of Fig. 4).

Simple estimates of the formation of $\mathrm{N}$ or NO from ion chemistry have been carried out both for the auroral region (e.g., Nicolet 1965; Brown 1968; Jones and Rees 1973) and for the middle atmosphere (e.g., Nicolet 1975; Rusch et al. 1981).

The most important reactions forming $\mathrm{N}$ and $\mathrm{NO}$ from ions are recombination of $\mathrm{N}_{2}{ }^{+}$ and $\mathrm{NO}^{+}$(e.g., Nicolet 1965; Jones and Rees 1973):

$$
\begin{array}{ll}
\mathrm{N}_{2}^{+}+e^{-} \rightarrow \mathrm{N}+\mathrm{N}^{*} & (\mathrm{R}-5(\mathrm{a})) \\
\mathrm{NO}^{+}+e^{-} \rightarrow \mathrm{N}+\mathrm{O} & (\mathrm{R}-5(\mathrm{~b}))
\end{array}
$$

charge transfer reactions of $\mathrm{N}^{+}$like (Nicolet 1975),

$$
\mathrm{N}^{+}+\mathrm{O} \rightarrow \mathrm{N}+\mathrm{O}^{+}
$$

or ion-neutral reactions like (e.g., Nicolet 1965; Jones and Rees 1973; Rusch et al. 1981)

$$
\begin{array}{cc}
\mathrm{O}^{+}+\mathrm{N}_{2} \rightarrow \mathrm{NO}^{+}+\mathrm{N} & (\mathrm{R}-7(\mathrm{a})) \\
\mathrm{O}_{2}^{+}+\mathrm{N}_{2} \rightarrow \mathrm{NO}^{+}+\mathrm{NO} & (\mathrm{R}-7(\mathrm{~b})) \\
\mathrm{N}_{2}^{+}+\mathrm{O} \rightarrow \mathrm{NO}^{+}+\mathrm{N} & (\mathrm{R}-7(\mathrm{c})) \\
\mathrm{N}^{+}+\mathrm{O}_{2} \rightarrow \mathrm{NO}^{+}+\mathrm{O} & (\mathrm{R}-7(\mathrm{~d})) \\
\mathrm{NO}^{+}+\mathrm{O} \rightarrow \mathrm{O}_{2}^{+}+\mathrm{N} . & (\mathrm{R}-7(\mathrm{e}))
\end{array}
$$

Considering that the main loss process for $\mathrm{NO}^{+}$is recombination, $\mathrm{R}-7(\mathrm{a}), \mathrm{R}-7(\mathrm{~b})$, and R-7(c) will form 2 NOx, R-7(d) and R-7(e) will form one NOx. $\mathrm{NO}^{+}$can also be formed from charge transfer reactions like (Jones and Rees 1973)

$$
\mathrm{O}_{2}^{+}+\mathrm{NO} \rightarrow \mathrm{NO}^{+}+\mathrm{O}_{2}
$$

which, however, are not a net production mechanism of NOx. Nicolet (1975) and Rusch et al. (1981) both estimated the contribution of $\mathrm{N}$ production from dissociative ionisation of $\mathrm{N}_{2}$ under the assumption that the $\mathrm{N}^{+}$produced forms $\mathrm{N}$ eventually, to $P(\mathrm{~N})=0.16$ IPR (Nicolet 1975) respectively $P(\mathrm{~N})=0.185$ IPR (Rusch et al. 1981). The slightly higher value of Rusch et al. (1981) is due to newer cross sections of the dissociative ionisation used in this publication. Rusch et al. (1981) also estimated additional production of $\mathrm{N}$ due to the ionic reaction of $\mathrm{O}^{+}$with $\mathrm{N}_{2}$ (R-7(a)), but only considered dissociative ionisation of $\mathrm{O}_{2}$ as a source of $\mathrm{O}$. This reaction is balanced by other reactions of $\mathrm{O}^{+}$, that is,

$$
\mathrm{O}^{+}+\mathrm{O}_{2} \rightarrow \mathrm{O}_{2}^{+}+\mathrm{O}
$$

Considering this, a contribution of $P(\mathrm{~N})=0.03 \mathrm{~N}$ per ion pair is estimated for this reaction chain by Rusch et al. (1981). Thus, the contribution of ion chemistry to the total production of NOx according to Rusch et al. (1981) is $P(\mathrm{~N})=(0.03+0.185) \mathrm{IPR}=$ 0.188 IPR compared to $P(\mathrm{~N})=(0.985-1.385)$ IPR due to direct production of $\mathrm{N}$ by dissociation and dissociative ionisation (Rusch et al. 1981, see also Sect. 2.2.1), amounting to about $13-19 \%$ of the total NOx production per ion pair due to ion-chemistry reactions. The total NOx production rate is (1.2-1.61) NOx/IPR [and not (1.31-1.61) NOx/IPR as given in Rusch et al. (1981)]. 
To evaluate these estimates, results from a state-of-the art ion-chemistry model of the middle atmosphere and MLT region are examined. The model used is the one-dimensional ion-neutral University of Bremen ion-chemistry model (UBIC), which is described in detail in "Appendix 2". For this investigation, UBIC was initialised on 25 October 2003, 12 UT, with temperature and trace species data from the whole atmosphere community climate model (WACCM, Marsh et al. 2007; Smith 2012) for a position of $70^{\circ} \mathrm{N} / 180^{\circ} \mathrm{E}$. In the lower thermosphere above $90 \mathrm{~km}$, NO was initialised with a constant mixing ratio of $1 \mathrm{ppm}$ to ensure that only energetic particle forcing during the reference model period is taken into account and not affected by thermospheric NO enhancements due to high geomagnetic activity of the previous days. The model runs at $70^{\circ} \mathrm{N} / 180^{\circ} \mathrm{E}$ from 25 October 2003 until 10 November 2003, a period that includes the major solar particle event on 29/30 October 2003 known as the "Halloween storm" and a second smaller solar event on $5 / 6$ November 2003. Temperatures do not vary in this one-dimensional model run. Direct production of $\mathrm{N}$ by dissociation and dissociative ionisation is included as $P(\mathrm{~N})=0.985$ IPR, corresponding to the lower estimate of Rusch et al. (1981), see also R-4(e); this is partitioned into ground- and excited states of $\mathrm{N}$ equally (see also Sect. 2.2.3). Results are shown averaged over the period of the largest particle forcing, from 13 UT on October 28-11 UT on October 30.

In Panel A of Fig. 5, the modelled effective net production rate of $\mathrm{N}\left({ }^{4} \mathrm{~S}\right)$ and $\mathrm{NO}$ per ion pair is shown, as well as the sum of $\mathrm{N}\left({ }^{4} \mathrm{~S}\right)$ and $\mathrm{NO}$ production per ion pair. How the effective production rates are derived from the model results is explained in "Appendix 2".

The effective net production of $\mathrm{N}+\mathrm{NO}$ has a constant value of $\sim 1.1 \mathrm{NOx} / \mathrm{IPR}$ in the stratosphere and lowermost mesosphere below $\sim 65 \mathrm{~km}$, so about $0.102 \mathrm{NOx} / \mathrm{IPR}$ are formed by ion chemistry, roughly $9 \%$ of the total NOx production. This is slightly lower than the value estimated by Rusch et al. (1981). The reason for the discrepancy is that $\mathrm{N}_{2}{ }^{+}$, $\mathrm{N}^{+}$, and $\mathrm{NO}^{+}$ions can also form cluster ions of the form $\mathrm{NO}^{+}\left(\mathrm{H}_{2} \mathrm{O}\right) n$, which may release $\mathrm{HNO}_{2}$ instead of $\mathrm{N}$ or NO (Kazil 2002):

$$
\mathrm{NO}^{+}\left(\mathrm{H}_{2} \mathrm{O}\right)_{3}+\mathrm{H}_{2} \mathrm{O} \rightarrow \mathrm{H}^{+}\left(\mathrm{H}_{2} \mathrm{O}\right)_{3}+\mathrm{HNO}_{2}
$$

Above $\sim 65 \mathrm{~km}$, the effective production rate of NOx/IPR increases with altitude and reaches a maximum of $\sim 1.8 \mathrm{NOx} / \mathrm{IPR}$ above $\sim 130 \mathrm{~km}$. The reason for the increase is the increasing importance of $\mathrm{O}_{2}{ }^{+}$and $\mathrm{NO}^{+}$, which become the most abundant ions in the lower thermosphere, while in the stratosphere and lower mesosphere, $\mathrm{H}^{+}$cluster ions are most abundant (Kopp et al. 1985, see also Panel B of Fig. 4). This has already been commented on by Nicolet (1975) and Rusch et al. (1981). N and NO production rates due to precipitating particles were also calculated using a full ion-chemistry model in the stratosphere and mesosphere $(50-90 \mathrm{~km}$ ) for the strong solar proton event of October 1989 with the Sodankylä ion-chemistry model (SIC) by Verronen et al. (2002). Qualitatively, the behaviour of the NOx production with altitude is very similar to the results shown here, but the absolute values are much lower because dissociation of $\mathrm{N}_{2}$ by secondary electrons is not considered in the version of SIC used by Verronen et al. (2002).

\subsubsection{Excited States of $N$ and Their Relevance for NOx Production}

Dissociation and dissociative ionisation of $\mathrm{N}_{2}$ as well as the recombination reactions of the $\mathrm{N}_{2}{ }^{+}$and $\mathrm{NO}^{+}$ion can form atomic nitrogen either in the ground $\mathrm{N}\left({ }^{4} \mathrm{~S}\right)$ state or in excited $\left(\mathrm{N}\left({ }^{2} \mathrm{D}\right), \mathrm{N}\left({ }^{2} \mathrm{P}\right)\right)$ states (e.g., Jones and Rees 1973; Porter et al. 1976; Roble and Rees 1977). Both can react with molecular oxygen or ozone to form NO: 

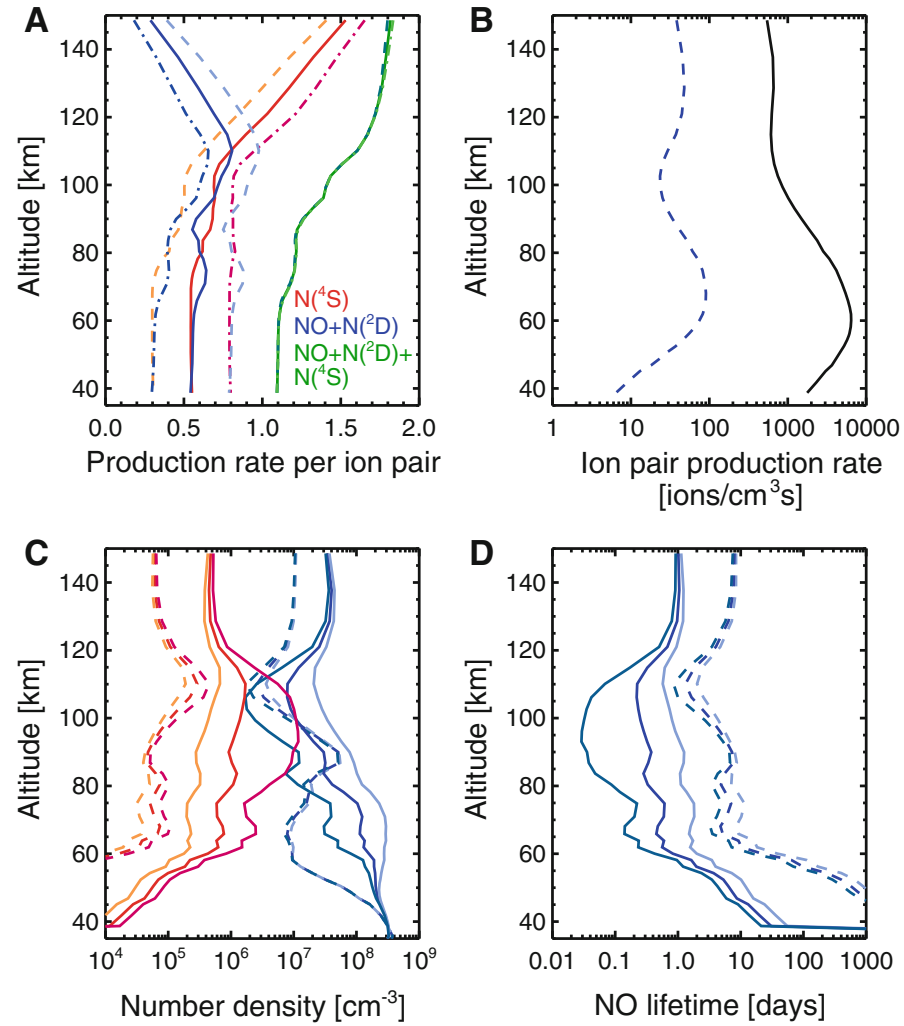

Fig. 5 Model results from the University of Bremen ion-chemistry model (UBIC, see "Appendix 2") before and during a large solar particle event on 29/30 October 2003.). A the modelled effective net production rates of $\mathrm{N}\left({ }^{4} \mathrm{~S}\right)($ red $), \mathrm{N}\left({ }^{2} \mathrm{D}\right)+\mathrm{NO}$ (blue) and $\mathrm{NOx}=\mathrm{N}\left({ }^{4} \mathrm{~S}\right)+\mathrm{N}\left({ }^{2} \mathrm{D}\right)+\mathrm{NO}$ (green). Three model runs were carried out with different initial $\mathrm{N}\left({ }^{4} \mathrm{~S}\right) / \mathrm{NOx}$ ratios: $25 \%$ (dashed lines, light colours), $50 \%$ (solid lines), and $75 \%$ (dash-dotted lines, dark colours). B Ionisation rates (molec $\mathrm{cm}^{-3} \mathrm{~s}^{-1}$ ) for the period of the largest particle forcing (28-30 October 2003, black solid line) and 2 days previous (26-28 October 2003, dashed blue line). C Modelled number density of NO (blue) and N( ${ }^{4} \mathrm{~S}$ ) (red) for 28-30 October 2003 (solid lines) and 26-28 October 2003 (dashed lines) as a function of altitude. Shown are results from all three model scenarios of the initial partitioning of $\mathrm{N}\left({ }^{4} \mathrm{~S}\right) / \mathrm{NOx}: 25 \%$ (light colours), 50, and $75 \%$ (dark colours). In the altitude region $60-100 \mathrm{~km}, \mathrm{~N}$ and $\mathrm{NO}$ densities vary up to one order of magnitude between the three model scenarios. D lifetime of NO due to the reaction $\mathrm{N}+\mathrm{NO}$ estimated from the results shown in the lower left panel, for the three model scenarios and the period of largest particle forcing (28-30 October 2003, solid lines) and the quiet "reference" period (26-28 October 2003, dashed lines)

$$
\begin{aligned}
& \mathrm{N}+\mathrm{O}_{2} \rightarrow \mathrm{NO}+\mathrm{O} \\
& \mathrm{N}+\mathrm{O}_{3} \rightarrow \mathrm{NO}+\mathrm{O}_{2}
\end{aligned}
$$$$
(\mathrm{R}-11(\mathrm{~b}))
$$

The reaction with $\mathrm{O}_{2}$ is much more efficient with the excited states in the stratosphere, mesosphere, and lower thermosphere (e.g., Nicolet 1975; Rusch et al. 1981; Barth 1992) and is a major source of NO there. The reaction of $\mathrm{O}_{2}$ with the ground-state $\mathrm{N}\left({ }^{4} \mathrm{~S}\right)$ is very temperature-dependent and becomes the major source of NO in the thermosphere above $\sim 120 \mathrm{~km}$ (e.g., Barth 1992; Dobbin et al. 2006). The ground $\mathrm{N}\left({ }^{4} \mathrm{~S}\right)$ state can also partake in a competing reaction with NO: 


$$
\mathrm{N}+\mathrm{NO} \rightarrow \mathrm{N}_{2}+\mathrm{O}
$$

This reaction is an effective loss mechanism for NOx. As the excited states of $\mathrm{N}$ will form NO while the ground state can also destroy NOx, the partitioning between the ground state and the excited states both from the dissociation, dissociative ionisation, and ion chemistry is a very important quantity determining the amount of NOx formed.

The partitioning between $\mathrm{N}$ and several excited states of $\mathrm{N}$ has been determined for dissociation and dissociative ionisation by Porter et al. (1976) from theoretical calculations of the cross sections and secondary electron production rates (see also Sect. 2.2.1). It was estimated that from the dissociation and dissociative ionisation, $45 \% \mathrm{~N}\left({ }^{4} \mathrm{~S}\right)$ are formed, and $55 \% \mathrm{~N}^{*}$ (considering different excited states including $\mathrm{N}\left({ }^{2} \mathrm{D}\right)$ and $\mathrm{N}\left({ }^{2} \mathrm{P}\right)$ as well as higher energetic states). This value is widely used in models of the stratosphere and mesosphere (e.g., Jackman et al. 2005a; Sinnhuber et al. 2003; Rohen et al. 2005; Funke et al. 2011, and references therein). The ratio of $\mathrm{N}\left({ }^{4} \mathrm{~S}\right) / \mathrm{N}^{*}$ is also investigated by Rusch et al. (1981) by scaling a one-dimensional neutral and ion-chemistry model to observed ozone losses during one solar particle event in August 1972 in the altitude range 30-55 km. Based on the comparison of observed and modelled ozone changes, they give a tentative recommendation for the partitioning of $\mathrm{N}\left({ }^{4} \mathrm{~S}\right)$ of $20 \%$, a value rather lower than obtained by Porter et al. (1976) from theoretical considerations. Recently, Baumgaertner et al. (2010) also estimated the partitioning of $\mathrm{N}\left({ }^{4} \mathrm{~S}\right)$ and $\mathrm{NO}$ by comparison between observed and modelled values; they fitted results of $\mathrm{NO}_{2}$ and $\mathrm{N}_{2} \mathrm{O}$ from a chemistry-climate model to observations from the MIPAS instrument during the October/November 2003 solar particle event by changing the formation rates of $\mathrm{N}\left({ }^{4} \mathrm{~S}\right)$ and $\mathrm{NO}$ separately in the model. Best agreement was obtained between model results and observations for an altitudedependent branching of $14-27 \%$ to $\mathrm{N}\left({ }^{4} \mathrm{~S}\right)$ in the altitude region $46-64 \mathrm{~km}$, in reasonably good agreement with the values of Rusch et al. (1981), lower than the value given by Porter et al. (1976) (see Table 1). Maximal values of the sum of $\mathrm{N}\left({ }^{4} \mathrm{~S}\right)$ and NO production reach $\sim 1.34 \mathrm{NOx} / \mathrm{IPR}$ around $54 \mathrm{~km}$, which is higher than the 'optimal' value of $1.27 \mathrm{NOx} / \mathrm{IPR}$ given by Porter et al. (1976) and the value of 1.25 NOx/IPR commonly used in global models of the middle atmosphere (e.g., Jackman et al. 2005a; Funke et al. 2011), but well within the uncertainty estimates of Rusch et al. (1981) and Porter et al. (1976).

In the following, the importance of the partitioning between $\mathrm{N}\left({ }^{4} \mathrm{~S}\right)$ and $\mathrm{N}^{*}$ in the primary dissociation and dissociative ionisation is assessed for the resultant increase in NOx; again, model results from the UBIC model for the large solar event of October 2003 are used. Results from this model run are shown in Fig. 5 for two periods: for the time of the largest proton forcing (17 UT on 28 October 2003, to 12 UT on 30 October 2003), and a 'quiet' reference period with much lower atmospheric ionisation from 17 UT on 26 October 2003 to 12 UT at 28 October 2003. The average ionisation rates for both periods are shown in Panel B of Fig. 5.

Table 1 Different estimates of the ratio between $\mathrm{N}\left({ }^{4} \mathrm{~S}\right)$ and total NOx produced by energetic particle impact

\begin{tabular}{lll}
\hline $\begin{array}{l}\mathrm{N}\left({ }^{4} \mathrm{~S}\right) / \mathrm{NOx} \\
(\%)\end{array}$ & Reference & Comments \\
\hline 45 & Porter et al. (1976) & Theoretical estimate \\
20 & $\begin{array}{l}\text { Rusch et al. (1981) } \\
\text { Baumgaertner et al. }\end{array}$ & $\begin{array}{l}\text { Derived from scaling model to observed ozone loss } \\
\text { dependent }\end{array}$ \\
\hline
\end{tabular}


The primary partitioning between $\mathrm{N}\left({ }^{4} \mathrm{~S}\right)$ and the excited states $\mathrm{N}^{*}$ was prescribed in three different ways: 25:75; 50:50; and 75:25. 50:50 is very near the value of Porter et al. (1976), while 25:75 is nearer to Rusch et al. (1981) and Baumgaertner et al. (2010). 75:25 appears quite unlikely both from the theoretical estimate and from comparison to observations. In Panel A of Fig. 5, the modelled effective production rates of $\mathrm{N}\left({ }^{4} \mathrm{~S}\right)$ and $\mathrm{NO}$ are shown for all three model scenarios. In Panel $\mathrm{C}$ of Fig. 5, the resulting absolute values of $\mathrm{N}\left({ }^{4} \mathrm{~S}\right)$ and NO are shown for the period of the largest particle forcing (17 UT on 28 October 2003 , to 12 UT on 30 October 2003) compared to the "quiet" reference period (17 UT on 26 October 2003 to 12 UT at 28 October 2003).

While the resulting effective production rate of NOx is nearly identical for all three cases, the productions of $\mathrm{N}\left({ }^{4} \mathrm{~S}\right)$ and $\mathrm{N}\left({ }^{2} \mathrm{D}\right)+\mathrm{NO}$ and the absolute values of $\mathrm{NO}$ respectively $\mathrm{N}$ differ quite considerably. Up to about $100 \mathrm{~km}$, the initial partitioning between $\mathrm{N}\left({ }^{4} \mathrm{~S}\right)$ and $\mathrm{N}\left({ }^{2} \mathrm{D}\right)$ is maintained in the effective production rates. In the lower thermosphere, the production of $\mathrm{N}\left({ }^{4} \mathrm{~S}\right)$ becomes dominant for all three scenarios even when the initial partitioning favours $\mathrm{N}\left({ }^{2} \mathrm{D}\right)$, because here, ion chemistry dominates the formation, and the most important process is the recombination of $\mathrm{NO}^{+}$with electrons (R-5) which forms $\mathrm{N}\left({ }^{4} \mathrm{~S}\right)$, not NO. In the absolute values of $\mathrm{NO}$ and $\mathrm{N}$, differences of about one order of magnitude are observed in the mesosphere and lowermost thermosphere between $\sim 65-$ $110 \mathrm{~km}$ among the three model scenarios (Panel $\mathrm{C}$ of Fig. 5). In this altitude range, the partitioning between the ground- and excited states of NO is therefore a very important value. Around $\sim 90 \mathrm{~km}$ altitude, values of $\mathrm{NO}$ for the period of the largest particle forcing are actually slightly lower than for the quiet reference period for the two model runs with $\mathrm{N}\left({ }^{4} \mathrm{~S}\right): \mathrm{N}^{*}$ of 50 and $75 \%$. Apparently, at these altitudes, the competing NOx-destroying reaction R-12 prevails over the NO formation reactions $\mathrm{R}-11$ if $\mathrm{N}(4 \mathrm{~S}): \mathrm{N}^{*}$ is equal to or larger than $1: 1$.

Below $\sim 60 \mathrm{~km}$, the partitioning is not as important because generally concentrations of $\mathrm{N}$ are too low for the reaction of $\mathrm{N}+\mathrm{NO}$ to be of equal importance; the lifetime of $\mathrm{NO}$ regarding this reaction is longer than 10 days even for a very large particle forcing (Panel $\mathrm{D}$ of Fig. 5). It should be pointed out here that the difference between theoretical values from Porter et al. (1976) and values of the partitioning derived from observations by Baumgaertner et al. (2010) and Rusch et al. (1981) has been derived from observations below $\sim 65 \mathrm{~km}$ where this partitioning appears to be not as important as at higher altitudes.

In the mid-thermosphere (above $\sim 115 \mathrm{~km}$ ), results from the three model scenarios also are quite similar, that is, there, the initial partitioning between $N\left({ }^{4} \mathrm{~S}\right)$ and $N\left({ }^{2} \mathrm{D}\right)$ is not as important as in the mesosphere and lowermost thermosphere.

To summarise, the initial partitioning between $\mathrm{N}\left({ }^{4} \mathrm{~S}\right)$ and the excited states $\mathrm{N}^{*}$ is very important for the derivation of NOx production due to energetic particle precipitation especially in the altitude region from $\sim 60$ to $115 \mathrm{~km}$. Considering the large spread between theoretical and empirical derivations of this value (see Table 1), this value needs to be reconsidered carefully.

\subsection{Release of HOx Due to Positive Ion Chemistry}

Another important mechanism during energetic particle precipitation events is the formation of $\mathrm{HOx}\left(\mathrm{H}, \mathrm{OH}, \mathrm{HO}_{2}\right)$ from water vapour $\left(\mathrm{H}_{2} \mathrm{O}\right)$. This has been discussed for the first time by Swider and Keneshea (1973) to explain the decrease in mesospheric ozone around 50-70 km observed by sounding rocket experiments during a solar particle event in November 1969 (Weeks et al. 1972). Swider and Keneshea (1973) estimated that one OH would be produced during the formation, and one $\mathrm{H}$ during the recombination, of oxonium 
$\left(\mathrm{H}_{3} \mathrm{O}^{+}\left(\mathrm{H}_{2} \mathrm{O}\right)\right)$, in total about $2 \mathrm{HOx}$ per ion pair, assuming that one $\mathrm{H}_{2} \mathrm{O}$ will release exactly $\mathrm{H}+\mathrm{OH}$ per ion pair. A similar approach was used in the follow-up studies by Swider et al. (1978) and Crutzen and Solomon (1980) in model studies about the ozone loss during SPEs. Solomon et al. (1981) did a thorough consideration of the ion-chemistry processes leading to a release of HOx during energetic particle precipitation events and found that the main process is the uptake of water vapour into large cluster ions and the subsequent release of $\mathrm{H}$ during recombination reactions of these cluster ions. The main processes are the production of $\mathrm{O}_{4}{ }^{+}$ions from the fundamental ionisation of $\mathrm{O}_{2}$, and uptake of water vapour:

$$
\begin{array}{cc}
\mathrm{O}_{2}^{+}+\mathrm{O}_{2} \rightarrow \mathrm{O}_{4}^{+} & (\mathrm{R}-13(\mathrm{a})) \\
\mathrm{O}_{4}^{+}+\mathrm{H}_{2} \mathrm{O} \rightarrow \mathrm{O}_{2}^{+}\left(\mathrm{H}_{2} \mathrm{O}\right)+\mathrm{O}_{2} & (\mathrm{R}-13(\mathrm{~b}))
\end{array}
$$

Larger cluster ions can then be formed by reaction pathways like:

$$
\begin{array}{cc}
\mathrm{O}_{2}^{+}\left(\mathrm{H}_{2} \mathrm{O}\right)+\mathrm{H}_{2} \mathrm{O} \rightarrow \mathrm{H}_{3} \mathrm{O}^{+}(\mathrm{OH})+\mathrm{O}_{2} & (\mathrm{R}-14(\mathrm{a})) \\
\mathrm{O}_{2}^{+}\left(\mathrm{H}_{2} \mathrm{O}\right)+\mathrm{H}_{2} \mathrm{O} \rightarrow \mathrm{H}^{+}\left(\mathrm{H}_{2} \mathrm{O}\right)+\mathrm{OH}+\mathrm{O}_{2} & (\mathrm{R}-14(\mathrm{~b}))
\end{array}
$$

Those can then be followed by the formation of larger protonised water cluster ions, like

$$
\begin{array}{cc}
\mathrm{H}_{3} \mathrm{O}^{+}(\mathrm{OH})+\mathrm{H}_{2} \mathrm{O} \rightarrow \mathrm{H}^{+}\left(\mathrm{H}_{2} \mathrm{O}\right)_{2}+\mathrm{OH} & (\mathrm{R}-15(\mathrm{a})) \\
\mathrm{H}^{+}\left(\mathrm{H}_{2} \mathrm{O}\right)_{n}+\mathrm{H}_{2} \mathrm{O} \rightarrow \mathrm{H}^{+}\left(\mathrm{H}_{2} \mathrm{O}\right)_{n+1} & (\mathrm{R}-15(\mathrm{~b}))
\end{array}
$$

During all these reaction chains, recombination reactions with electrons can take place:

$$
\begin{array}{cc}
\mathrm{H}_{3} \mathrm{O}^{+}(\mathrm{OH})+\mathrm{e}^{-} \rightarrow \mathrm{H}_{2} \mathrm{O}+\mathrm{H}+\mathrm{OH} & (\mathrm{R}-16(\mathrm{a})) \\
\mathrm{H}^{+}\left(\mathrm{H}_{2} \mathrm{O}\right)_{n}+\mathrm{e}^{-} \rightarrow \mathrm{H}+\mathrm{nH}_{2} \mathrm{O} & (\mathrm{R}-16(\mathrm{~b}))
\end{array}
$$

In this chain of reactions, $\mathrm{HOx}$ is produced in different steps, in the form of $\mathrm{OH}$ during the formation (Reactions R-14(b) and R-15(a)), and in the form of H during the recombination (Reaction R-16(a) and R-16(b)), of the $\mathrm{H}^{+}$-cluster ions; thus, strictly one $\mathrm{OH}$ and one $\mathrm{H}$ is formed for every $\mathrm{H}^{+}$-cluster ion. It has been discussed already by Solomon et al. (1981) that the formation of HOx from atmospheric ionisation must be dependent on altitude, because (1) the primary reaction R-13(a) is pressure dependent and (2) water vapour decreases strongly in the mesosphere due to photolysation by Ly- $\alpha$ radiation, and subsequent formation of $\mathrm{H}_{2}$. Water cluster ions are the most abundant positive ion species in the stratosphere and lower mesosphere, but do not form above $\sim 80 \mathrm{~km}$ (Kopp et al. 1985, see also Panel A of Fig. 6). Therefore, it is unlikely that HOx production is very efficient in the upper mesosphere and lower thermosphere, but it can be very efficient in the middle and lower mesosphere, and in the stratosphere. There is a concurring reaction pathway that leads to a lower HOx production due to the reaction of protonised water cluster ions with negative $\mathrm{NO}_{3}{ }^{-}$containing ions:

$$
\mathrm{H}^{+}\left(\mathrm{H}_{2} \mathrm{O}\right)_{n}+\mathrm{NO}_{3}^{-}\left(\mathrm{HNO}_{3}\right)_{m} \rightarrow \mathrm{HNO}_{3}+n \mathrm{H}_{2} \mathrm{O}+m \mathrm{HNO}_{3}
$$

This is also discussed by Solomon et al. (1981). As negative ions are only important at altitudes below $\sim 80 \mathrm{~km}$ (see Panel A of Fig. 4), this chain of reactions is more likely to be important in the lower mesosphere and stratosphere.

Water cluster ions can also be formed by reaction of $\mathrm{NO}^{+}$cluster ions with water vapour, see Reaction R-10 (Kazil 2002). $\mathrm{NO}^{+}$can be formed by a number of reactions, both from the primary $\mathrm{N}_{2}^{+}, \mathrm{N}^{+}, \mathrm{O}^{+}$and $\mathrm{O}_{2}{ }^{+}$ions (R-7(a), R-7(b), R-7(c), and R-7(d)), and 

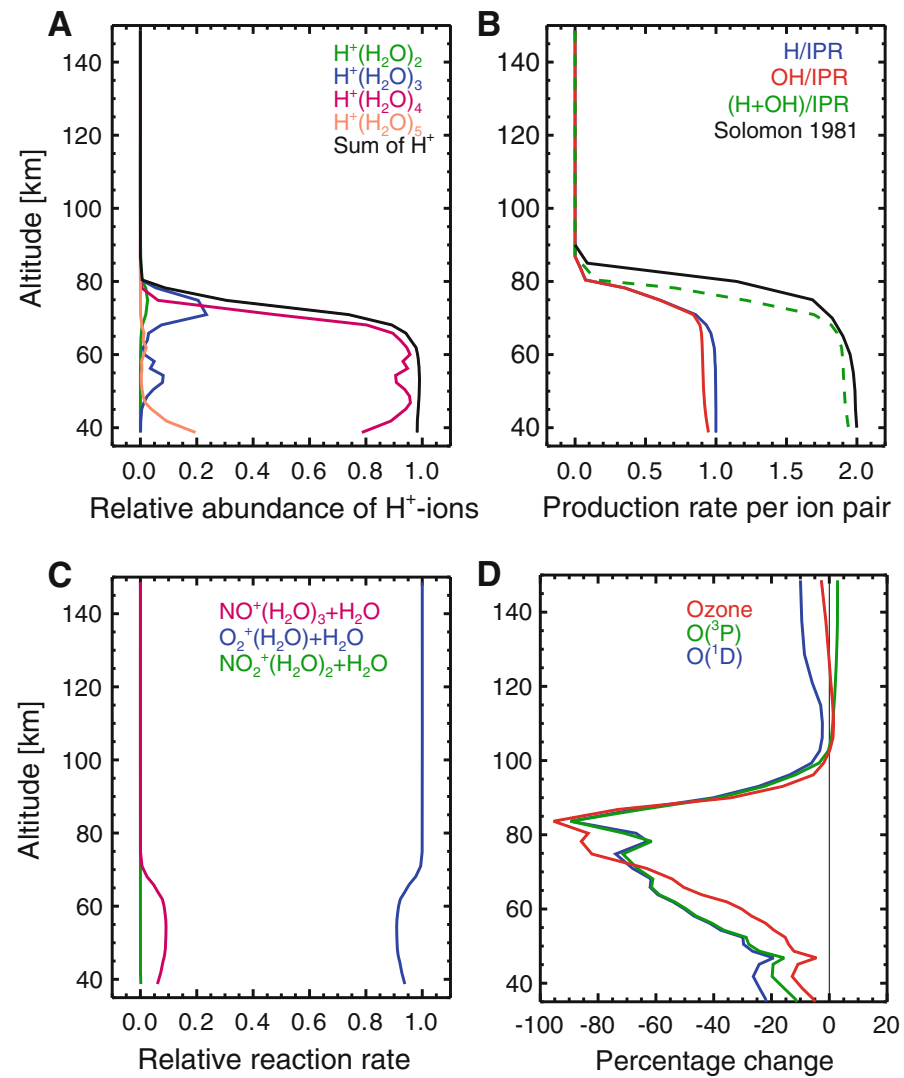

Fig. 6 Model results from the UBIC model (see "Appendix 2") before and during a large solar particle event on 29/30 October 2003. A abundance of protonised water cluster ions relative to the total ion density. Coloured lines water cluster ions with 2, 3, 4, and 5 water molecules attached; black line sum of all protonised water cluster ions. B production of $\mathrm{H}, \mathrm{OH}$, and $\mathrm{HOx}$ per ion pair. Blue $\mathrm{H}$ production per ion pair; red: $\mathrm{OH}$ production per ion pair; green dashed $\mathrm{H}+\mathrm{OH}$ per ion pair, and black $\mathrm{H}+\mathrm{OH}$ per ion pair using the parameterisation of Solomon et al. (1981) as first given by Jackman et al. (2005a). C Relative contribution of different reactions to the formation of water cluster ions. Red R-10, blue R-14. D percentage change of $\mathrm{O}_{3}($ red $), \mathrm{O}\left({ }^{1} \mathrm{D}\right)($ blue $)$, and $\mathrm{O}\left({ }^{3} \mathrm{P}\right)($ green $)$ due to the solar particle event (28-30 October 2003) relative to a quiet period (26-28 October 2003)

from charge transfer reactions of different ions with NO R-8. The chain of reactions from $\mathrm{NO}^{+}$to water cluster ions will provide one $\mathrm{H}$ from the recombination of the water cluster ion, but will not provide $\mathrm{OH}$, thus lowering the net production of $\mathrm{HOx}$ and the ratio of $\mathrm{OH}$ to $\mathrm{H}$ production.

Solomon et al. (1981) estimated the formation of HOx as a function of the ionisation rate and altitude, considering the formation rates of $\mathrm{N}^{+}$and $\mathrm{O}^{+}$from Rusch et al. (1981), and the branching of the different reaction pathways that yield HOx. From this, they derive a formula for HOx production that depends on atmospheric ionisation, the electron density, total air density, several reaction rates, and the neutral gases $\mathrm{NO}, \mathrm{H}_{2} \mathrm{O}$, and $\mathrm{O}$. They also show the dependency of the HOx production as a function of altitude and ionisation rate for polar summer daytime conditions: for low ionisation rates and altitudes below $\sim 60 \mathrm{~km}, 2$ HOx are formed per ion pair. HOx production decreases for increasing altitudes and is 
negligible for altitudes above $85 \mathrm{~km}$. HOx production also decreases for increasing ionisation rates because recombination reactions of $\mathrm{O}_{2}{ }^{+}$and $\mathrm{O}_{4}{ }^{+}$, which do not contribute to the HOx production, become more important for higher electron densities. Those results by Solomon et al. (1981) are widely used as a parameterisation of HOx production in neutral models of the atmosphere (e.g., Jackman et al. 2005a; Funke et al. 2011). It is usually assumed that $\mathrm{H}$ and $\mathrm{OH}$ are formed in equal amounts.

This is investigated further in the following using model results from the UBIC model for the period of large solar proton forcing around 28-30 October 2003 discussed already above. The effective modelled formation rates of $\mathrm{H}, \mathrm{OH}$, and $\mathrm{H}+\mathrm{OH}$ per ion pair are shown as a function of altitude in Panel $\mathrm{B}$ of Fig. 6. Below $\sim 70 \mathrm{~km}$, one $\mathrm{H}$ is formed per ion pair as expected for the mid- and lower mesosphere; however, the formation rate of $\mathrm{OH}$ is slightly lower, around $0.9 \mathrm{OH}$ per ion pair, and the sum of $\mathrm{H}+\mathrm{OH}$ is therefore also lower than $2 \mathrm{HOx}$ per ion pair. The reason for this is production of water cluster ions from $\mathrm{NO}^{+}\left(\mathrm{H}_{2} \mathrm{O}\right) n$ (R-10), which forms about $8-10 \%$ of the water cluster ions (see Panel $\mathrm{C}$ of Fig. 6). Above $\sim 70 \mathrm{~km}$, HOx production decreases quickly with altitude and becomes negligible above $\sim 80 \mathrm{~km}$. This is in good qualitative agreement with the results of Solomon et al. (1981). A comparison of the total HOx production rate derived from the UBIC model with the parameterisation based on Solomon et al. (1981) as given first by Jackman et al. (2005a) is shown in Panel B of Fig. 6. UBIC values are slightly lower than the parameterisation based on Solomon et al. (1981) everywhere and decrease more steeply and at lower altitudes. One reason for the discrepancy between UBIC values and the parameterisation is the formation of protonised water cluster ions by $\mathrm{NO}^{+}\left(\mathrm{H}_{2} \mathrm{O}\right) n$ containing ions, which does not contribute to the formation of $\mathrm{OH}$. Another reason may be that the parameterisation only considers the dependency on ion density and altitude, while the HOx production also depends on the amount of water vapour and atomic oxygen (e.g., Solomon et al. 1981).

\subsection{Ozone Loss}

It had been recognised for the first time by Bates and Nicolet (1950) that, above, $60 \mathrm{~km}$, catalytic cycles with HOx are an important loss mechanism for ozone:

$$
\begin{array}{ll}
\mathrm{H}+\mathrm{O}_{3} \rightarrow \mathrm{OH}+\mathrm{O}_{2} & (\mathrm{R}-18(\mathrm{a})) \\
\mathrm{OH}+\mathrm{O} \rightarrow \mathrm{H}+\mathrm{O}_{2} & (\mathrm{R}-18(\mathrm{~b}))
\end{array}
$$

In every chain of this reaction, one $\mathrm{Ox}\left(\mathrm{O}_{3}, \mathrm{O}\left({ }^{3} \mathrm{P}\right), \mathrm{O}\left({ }^{1} \mathrm{D}\right)\right)$ is lost while the reactants $\mathrm{H}$ and $\mathrm{OH}$ are reformed; thus, $\mathrm{Ox}$ is lost very efficiently. Therefore, energetic particle precipitation can be a source of significant ozone loss especially in the mesosphere. Similar reactions involving odd nitrogen species can also lead to catalytic ozone loss (Crutzen 1970). However, odd nitrogen is most effective for ozone loss below $\sim 45 \mathrm{~km}$, that is, in the stratosphere (Lary 1997); for the instantaneous ozone loss in the mesosphere due to energetic particle precipitation, odd hydrogen is more important at least during day-time; during night-time, catalytic cycles both with HOx and NOx could be possible during energetic particle precipitation events as long as $\mathrm{OH}, \mathrm{O}$, and $\mathrm{NO}$ are formed, but to our knowledge, this has not been investigated yet. Low values of mesospheric ozone have been observed during a large polar cap absorption event already in 1969 (Weeks et al. 1972) and were explained as a result of the formation of odd hydrogen soon afterwards (Swider and Keneshea 1973). In Panel D of Fig. 6, the percentage change of ozone, $O\left({ }^{3} \mathrm{P}\right)$, and $\mathrm{O}\left({ }^{1} \mathrm{D}\right)$ are shown during the large particle forcing of 28-30 October 2003, relative to the quiet 
"reference" period of 26-28 October 2003. The percentage change of $\mathrm{O}_{3}, \mathrm{O}\left({ }^{3} \mathrm{P}\right)$, and $\mathrm{O}\left({ }^{1} \mathrm{D}\right)$ is quite similar, with the largest values of more than $80 \%$ of ozone loss between $\sim 65$ and $90 \mathrm{~km}$. Above $100 \mathrm{~km}$, odd oxygen change becomes very small and is indeed positive for $\mathrm{O}_{3}$ and $\mathrm{O}\left({ }^{3} \mathrm{P}\right)$, possibly because of the formation of atomic oxygen due to dissociation and dissociative ionisation of $\mathrm{O}_{2}$ as discussed by Porter et al. (1976, see also Sect. 2.2.1); this process is included in the model with the rather lower estimate of Rusch et al. (1981) of $0.076 \mathrm{O}$ per ion pair. Below $65 \mathrm{~km}$, odd oxygen loss decreases slowly and reaches more or less constant values of 10-20\% below $50 \mathrm{~km}$. In the altitude range of the largest loss of odd oxygen, odd hydrogen has a lifetime of a few hours only; most of the odd hydrogen will then convert to $\mathrm{H}_{2}$, so that water vapour is effectively reduced by the atmospheric ionisation (e.g., Crutzen and Solomon 1980). This means that after a large energetic particle precipitation event-that is, a solar particle event or geomagnetic storm-ozone could increase in the mid- to upper mesosphere as a result of the atmospheric ionisation, because in the quiet atmosphere, the main reservoir of odd hydrogen is photolysis of $\mathrm{H}_{2} \mathrm{O}$, and this is effectively reduced by the energetic particle event (e.g., Solomon et al. 1981). However, in the lower mesosphere and stratosphere, ozone loss could continue for weeks after a large particle event because there, ozone loss is due to NOx, which can be quite long-lived especially during polar winter. This will be discussed in more detail in Sect. 3.1.

\subsection{Other Species: Chlorine, $\mathrm{HNO}_{3}$, and $\mathrm{N}_{2} \mathrm{O}$}

Production of odd nitrogen and odd hydrogen and subsequent ozone loss are the most wellknown and also most striking consequences of energetic particle precipitation. However, the good coverage of the middle atmosphere by global observations in recent years has led to the discovery of other changes to the composition of the middle atmosphere besides NOx and HOx formation and subsequent ozone loss during and after energetic particle precipitation events. Those are also interpreted as a result of ion-chemistry reactions, namely the formation of chlorine due to negative ion chemistry (Winkler et al. 2009, 2011), the re-partitioning of nitrogen species from $\mathrm{N}_{2} \mathrm{O}_{5}$ to $\mathrm{HNO}_{3}$, both due to recombination reactions (Verronen et al. 2008), and due to water cluster ion reaction chains (Böhringer et al. 1983; de Zafra and Smyshlyaev 2001), and the formation of $\mathrm{N}_{2} \mathrm{O}$, whose dominant reaction pathway is yet not clear. They will be discussed shortly in the following.

\subsubsection{Chlorine}

Negative ions will react with $\mathrm{HCl}$ forming $\mathrm{Cl}^{-}$ions. $\mathrm{Cl}^{-}$then can form larger cluster ions which will release $\mathrm{Cl}$ during recombination:

$$
\begin{aligned}
\mathrm{HCl}+\mathrm{X}^{-} & \rightarrow \mathrm{Cl}^{-}+\mathrm{HX} & (\mathrm{R}-19(\mathrm{a})) \\
\mathrm{Cl}^{-}+\mathrm{Y} & \rightarrow \mathrm{Cl}^{-}(\mathrm{Y}) & (\mathrm{R}-19(\mathrm{~b})) \\
\mathrm{Cl}^{-}(\mathrm{Y})+\mathrm{Z}^{+} & \rightarrow \mathrm{Cl}+\mathrm{Z}+\mathrm{Y} & (\mathrm{R}-19(\mathrm{c}))
\end{aligned}
$$

The reactants in this reaction chain could be $\mathrm{X}=\mathrm{O}, \mathrm{O}_{2}, \mathrm{CO}_{3}, \mathrm{OH}, \mathrm{NO}_{2}, \mathrm{NO}_{3}$; $\mathrm{Y}=\mathrm{HCl}, \mathrm{H}_{2} \mathrm{O}, \mathrm{CO}_{2}$, and $\mathrm{Z}$ : any positive ion. This chain of reactions was first discussed by Kopp and Fritzenwallner (1997) and Fritzenwallner and Kopp (1998). Winkler et al. (2009, 2011) recognised that though the $\mathrm{Cl}^{-}$cluster ions could also release $\mathrm{HCl}$ in reactions with neutrals, Reactions R-19(a) to R-19(c) could be an effective source of chlorine activation 
in the lower mesosphere $(\sim 46-64 \mathrm{~km})$ during large solar proton events. Chlorine activation, that is, the decrease of the chlorine reservoir species $\mathrm{HCl}$ and the increase of reactive chlorine species $(\mathrm{ClO}, \mathrm{HOCl})$, has indeed been observed during large particle events (Winkler et al., 2009; von Clarmann et al. 2005); one example is shown in Fig. 7.

\subsection{2 $\mathrm{HNO}_{3}$}

There are two different pathways that can affect the amount of $\mathrm{HNO}_{3}$ in the lower mesosphere and stratosphere due to ion-chemistry reactions. Protonised water cluster ions can take up $\mathrm{N}_{2} \mathrm{O}_{5}$ in a chain of reactions that catalytically form $\mathrm{HNO}_{3}$ :

$$
\begin{array}{ll}
\mathrm{N}_{2} \mathrm{O}_{5}+\mathrm{H}^{+}\left(\mathrm{H}_{2} \mathrm{O}\right)_{n} \rightarrow \mathrm{H}^{+}\left(\mathrm{H}_{2} \mathrm{O}\right)_{n-1}\left(\mathrm{HNO}_{3}\right)+\mathrm{HNO}_{3} & (\mathrm{R}-20(\mathrm{a})) \\
\mathrm{H}^{+}\left(\mathrm{H}_{2} \mathrm{O}\right)_{n-1}\left(\mathrm{HNO}_{3}\right)+\mathrm{H}_{2} \mathrm{O} \rightarrow \mathrm{H}^{+}\left(\mathrm{H}_{2} \mathrm{O}\right)_{n}+\mathrm{HNO}_{3} & (\mathrm{R}-20(\mathrm{~b}))
\end{array}
$$

This catalytic reaction chain effectively destroys one $\mathrm{N}_{2} \mathrm{O}_{5}$ and one $\mathrm{H}_{2} \mathrm{O}$ and forms two $\mathrm{HNO}_{3}$, while the reactant (the water cluster ion) is reformed. It was first discussed by Böhringer et al. (1983) and has been discussed since then in a number of publications as a formation pathway of $\mathrm{HNO}_{3}$ due to GCR (Kawa et al. 1995; de Zafra and Smyshlyaev 2001; Lopez-Puertas et al. 2005b; Stiller et al. 2005; Orsolini et al. 2005, 2009). However, this chain of reactions is not very efficient above $40 \mathrm{~km}$ (Aikin 1997; Verronen et al. 2008) and therefore does not contribute to the mesospheric composition.

Another chain of reactions forming $\mathrm{HNO}_{3}$ from ion chemistry is due to the recombination reaction of protonised water cluster ions with negative $\mathrm{NO}_{3}{ }^{-}$containing ions $\mathrm{R}-17$, which is also important because it suppresses HOx production by water cluster ions, see Sect. 2.3. This reaction was first discussed by Aikin (1997), and later, it was shown by Verronen et al. (2008) that this reaction is very efficient in the lower mesosphere and stratosphere (below $\sim 70 \mathrm{~km}$ ) and could therefore very efficiently produce $\mathrm{HNO}_{3}$ below $\sim 70 \mathrm{~km}$ during large energetic particle precipitation events. A similar reaction is also possible if $\mathrm{H}_{2} \mathrm{O}$ is attached to the $\mathrm{NO}_{3}{ }^{-}$instead of $\mathrm{HNO}_{3}$ (Verronen et al. 2008):
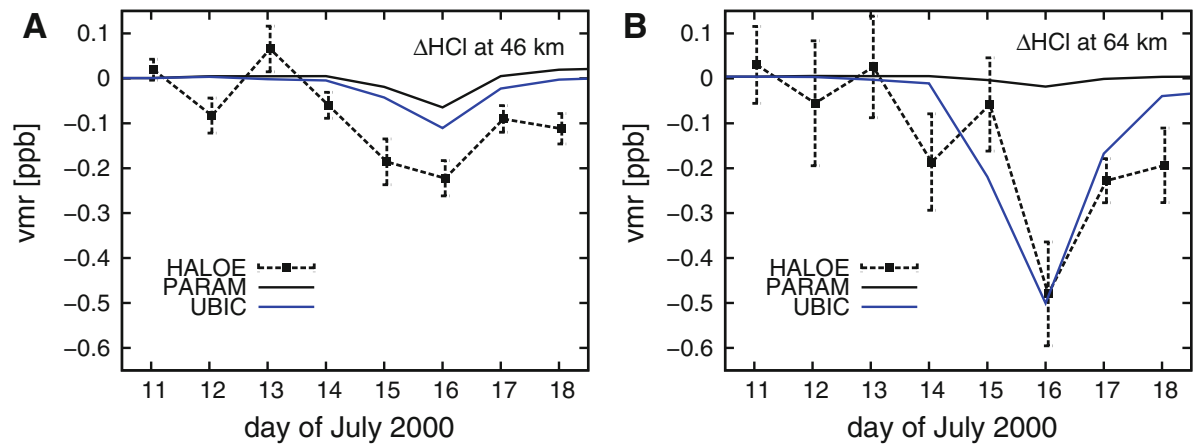

Fig. 7 Zonally averaged change of $\mathrm{HCl}$ volume mixing ratio (vmr) at $66.5^{\circ} \mathrm{N}$ as observed by HALOE/ UARS during the large solar particle event of 14/15 July 2000 (black dots), at $46 \mathrm{~km}$ (A) and $64 \mathrm{~km}$ (B). Error bars are the standard deviation of the mean. Blue line UBIC model results including negative ion chemistry. Black solid line model run without negative ion chemistry, but including parameterised NOx and HOx production. Figure adapted from Winkler et al. (2011). Figure copyright by AGU 


$$
\mathrm{H}^{+}\left(\mathrm{H}_{2} \mathrm{O}\right)_{n}+\mathrm{NO}_{3}^{-}\left(\mathrm{H}_{2} \mathrm{O}\right)_{m} \rightarrow \mathrm{HNO}_{3}+(n+m) \mathrm{H}_{2} \mathrm{O}
$$

However, this reaction chain is not mentioned in either Aikin (1997) or Verronen et al. (2011).

Significant enhancements of $\mathrm{HNO}_{3}$ during large SPEs have indeed been observed during the Halloween storm of October/November 2003 (Lopez-Puertas et al. 2005b; Orsolini et al. 2005) as well as during the smaller SPEs in January 2005 and December 2006 (Verronen et al. 2011b). It should be noted that in this reaction, as in the protonised ion cluster chain, $\mathrm{HNO}_{3}$ is not formed at the expense of $\mathrm{N}_{2}$ as in the primary $\mathrm{NOx}$ formation discussed in Sect. 2.2.1; $\mathrm{NO}_{3}{ }^{-}$containing ions are formed by reactions of nitrogen-containing species like $\mathrm{ClONO}_{2}, \mathrm{HNO}_{3}, \mathrm{~N}_{2} \mathrm{O}_{5}$, or $\mathrm{NO}_{2}$, with negative ions.

\subsection{3 $\mathrm{N}_{2} \mathrm{O}$}

Two pathways have been discussed by which $\mathrm{N}_{2} \mathrm{O}$ could be formed as a result of energetic particle precipitation in the mesosphere. Zipf and Prasad (1980) and Prasad and Zipf (1981) have proposed a reaction pathway involving excitation of $\mathrm{N}_{2}$ to $\mathrm{N}_{2}\left(\mathrm{~A} \Sigma_{\mathrm{u}}^{+}\right)$by auroral electrons followed by a reaction with $\mathrm{O}_{2}$ :

$$
\mathrm{N}_{2}\left(\mathrm{~A} \Sigma_{u}^{+}\right)+\mathrm{O}_{2} \rightarrow \mathrm{N}_{2} \mathrm{O}+\mathrm{O}
$$

Based on laboratory estimates of the cross section of this reaction by Zipf et al. (1980), they estimated that this reaction could produce $\mathrm{N}_{2} \mathrm{O}$ values comparable to NO in the aurora in the altitude range between $\sim 80$ and $120 \mathrm{~km}$, with maximal production rates around $100 \mathrm{~km}$ (Zipf and Prasad 1980; Funke et al. 2008a). Above $120 \mathrm{~km}$, quenching reactions with atomic oxygen and radiation in the Vegard-Kaplan bands of $\mathrm{N}_{2}$ dominate. However, other estimates of the rate of reaction R-22 give significantly lower values than Zipf (1980), as summarised, for example, in de Sousa et al. (1985); thus, this reaction pathway is likely less significant than estimated by Zipf and Prasad (1980) and Prasad and Zipf (1981). Another pathway is the neutral gas-phase reaction of $\mathrm{N}$ with $\mathrm{NO}_{2}$ :

$$
\mathrm{N}+\mathrm{NO}_{2} \rightarrow \mathrm{N}_{2} \mathrm{O}+\mathrm{O}
$$

This was discussed first by Semeniuk et al. (2008) and Funke et al. (2008a). $\mathrm{NO}_{2}$ is available in large abundances in the mesosphere only during night-time, when atomic nitrogen values are usually quite low; this reaction pathway therefore only plays a role during night-time if atomic nitrogen is provided by energetic particle precipitation-in the auroral or radiation-belt latitudes. As $\mathrm{NO}_{2}$ is destroyed by reaction with atomic oxygen above $80 \mathrm{~km}$, this reaction is efficient only at altitudes below $80 \mathrm{~km}$ (Semeniuk et al. 2008), with a maximal efficiency around 70-75 km during night-time, around 50-60 km during day-time (Funke et al. 2008a). Enhanced values of $\mathrm{N}_{2} \mathrm{O}$ in the mesosphere were observed during the large solar event of October/November 2003 (Funke et al. 2008b), but also during several Arctic and Antarctic winters in the absence of large solar events (Semeniuk et al. 2008; Funke et al. 2008a). In the latter case, the source of the $\mathrm{N}_{2} \mathrm{O}$ was probably particle precipitation in the upper mesosphere; however, as observations were restricted in both cases to altitudes below $70 \mathrm{~km}$, below the source of the $\mathrm{N}_{2} \mathrm{O}$ production, it is not clear which of the two reaction pathways dominates, as discussed, for example, by Funke et al. (2008a). 


\section{Interaction with Atmospheric Dynamics and Long-Term Impacts of Energetic Particle Precipitation (EPP)}

The most important changes to the composition of the MLT region are the formation of NOx due to dissociation, dissociative ionisation and ionisation of $\mathrm{N}_{2}$, and subsequent ion chemistry, the formation of $\mathrm{HOx}$ from positive ion chemistry, and subsequent loss of odd oxygen; in the lower thermosphere, formation of atomic oxygen due to dissociation and dissociative ionisation of $\mathrm{O}_{2}$ also plays a role. Those changes affect primarily the chemical composition of the mesosphere and lower thermosphere. However, they can also interact with atmospheric dynamics in two ways: changes to the chemical composition can be transported to other atmospheric regions (i.e. the atmosphere below) in large-scale transport patterns, and they can in turn affect atmospheric dynamics by changing the heating and cooling rates of the atmosphere. Both processes are discussed in the following.

\subsection{Coupling to the Atmosphere Below}

Energetic particle precipitation (EPP) leads to an increase in NOx which is especially strong in the thermosphere. Already in 1975, Nicolet (1975) discussed the possibility that these large thermospheric values could be a source of NO also in the mesosphere and stratosphere. Initially, this idea was rejected on the basis of one-dimensional model calculations because the eddy diffusion is too low to mix thermospheric NO into the mesosphere and stratosphere (Brasseur and Nicolet 1973; Nicolet 1975). This question was reinvestigated some time later using a two-dimensional model with an auroral NO source in the thermosphere by Solomon et al. (1982); they found that, if both vertical and horizontal transport are accounted for, transport of auroral NO from the lower thermosphere into the middle atmosphere is possible and can lead to significant enhancements of NOx in the mesosphere and stratosphere. However, the impact is restricted mainly to high latitudes during winter-time. There are two reasons for this. The only loss mechanism for NOx is the reaction of atomic nitrogen with $\mathrm{NO}$, which forms $\mathrm{N}_{2}$ (Reaction R-12), and a similar reaction of $\mathrm{N}$ with $\mathrm{NO}_{2}$ which forms $\mathrm{N}_{2} \mathrm{O}$ (R-23).

In the absence of energetic particle forcing, the only source of atomic nitrogen is photolysis of NO; therefore, this reaction depends strongly on solar illumination, and the lifetime of NOx becomes very large (weeks to months) during polar winter in the mesosphere and lower thermosphere. Also, large-scale downwelling in the middle atmosphere is possible only during polar winter (Solomon et al. 1982, see also Smith 2012). As NOx very efficiently destroys ozone in the upper and mid-stratosphere below $\sim 45 \mathrm{~km}$ (Crutzen 1970; Lary 1997), this could also have an impact on stratospheric ozone (Solomon et al. 1982). This mechanism of transport of thermospheric NO from the auroral region into the middle atmosphere during polar winter was later coined the 'EPP indirect effect' (Randall et al. 2007).

\subsubsection{Observation of the EPP Indirect Effect}

The model predictions of Solomon et al. (1982) of enhanced NOx values in the middle atmosphere during polar winter were confirmed shortly afterwards by observations of enhanced mesospheric $\mathrm{NO}_{2}$ values in the Northern polar winter 1978-1979 from the LIMS instrument on Nimbus-7 (Russell et al. 1984). With the launch of satellite instruments like, for example, HALOE and POAM II, and the space shuttle experiment ATLAS in the early 1990s, longer time series of global observations of NOx became available in the middle 
atmosphere. These data provided confirmation that the EPP indirect effect is a common phenomenon in polar winter and spring (Siskind and Russell 1996; Siskind et al. 1998; Randall et al. 1998; Rinsland et al. 1999). It was shown that in the Southern hemisphere, NOx enhancements can propagate down to altitudes below $\sim 30 \mathrm{~km}$ and therefore lead to substantial ozone loss in the Southern hemisphere polar spring stratosphere (Randall et al. 1998). The interannual variability of these stratospheric NOx enhancements is correlated to the geomagnetic Ap index, suggesting that the source of the disturbance is auroral NOx production probably in the lower thermosphere (Randall et al. 1998, 2007; Siskind et al. 2000). In the Northern hemisphere, enhanced NOx values were found to be less apparent than in the Southern hemisphere before the Arctic winter 2003/2004. The interhemispheric difference is attributed to the stronger, more stable polar vortex in the Southern hemisphere polar winter compared to the Northern hemisphere, driven by the stronger (westward) gravity wave drag in the mesosphere, and leading to stronger downwelling of mesospheric air during Southern hemisphere polar winter compared to the dynamically more active Northern hemisphere (Siskind et al. 2000). However, careful analysis of new data observations during polar night (Seppälä et al. 2007b; Lu et al. 2008a) and of the whole HALOE time series from 1991 to 2005 (Sinnhuber et al. 2011) have recently shown that, in the upper stratosphere and mesosphere, NOx is well correlated to the Ap index (or the Ae index) during high polar winter also in the Northern hemisphere.

In Arctic winter 2003/2004, strongly enhanced values of NOx were observed by a number of satellite instruments in the Northern polar atmosphere descending from the mesosphere in mid-January 2004 to the stratosphere in March/April 2004 (e.g., Randall et al. 2005; Lopez-Puertas et al. 2006; Hauchecorne et al. 2007; Randall et al. 2007; Seppälä et al. 2007a). Observed values during polar night exceeded all observed enhancements in the Southern hemisphere (e.g., Lopez-Puertas et al. 2006; Seppälä et al. 2007a). This strong enhancement was attributed to a combination of high geomagnetic activity leading to high levels of thermospheric (and possibly upper mesospheric) NO in late 2003, with an unusual dynamical situation: a strong sudden stratospheric warming followed by reformation of a very strong polar vortex with strong and stable downwelling (e.g., Randall et al. 2005; Hauchecorne et al. 2007; Seppälä et al. 2007a).

Several publications attributed part of the observed NOx enhancements to direct production in the mesosphere due to radiation-belt electrons (e.g., Renard et al. 2006; Clilverd et al. 2007); however, the observed correlation with dynamical tracers seems to suggest that the source is mainly in the thermosphere or upper mesosphere (i.e. the auroral region) (Lopez-Puertas et al. 2006), and therefore, the contribution from direct production in the mesosphere or even upper stratosphere must be small compared to the auroral source. Indirect evidence for a strong enhancement of NO in the mesosphere in early 2004 comes from observations of enhanced radio wave propagation, an indicator of atmospheric ionisation assumedly due to photoionisation of NO (Clilverd et al. 2007). The role of unusual sudden stratospheric warmings is discussed further in Sect. 3.1.3.

\subsubsection{Impact on Ozone: Model Studies}

Several authors have pointed out that the enhanced stratospheric NOx values due to the EPP indirect effect will have a strong impact on stratospheric ozone. However, this is difficult to quantify from observations alone, because stratospheric ozone has quite a high year-to-year variability anyway (e.g., Randall et al. 2007; Seppälä et al. 2007b). The impact on stratospheric ozone therefore can be quantified more precisely using global models that incorporate the EPP indirect effect. Model investigations of this kind have 
been carried out with two-dimensional models in the past (e.g., Solomon et al. 1982; Siskind et al. 1997; Vitt et al. 2000a, b), and more recently, with global three-dimensional chemistry-climate models: with the Hamburg model of the Neutral and Ionized Atmosphere (HAMMONIA, Schmidt et al. 2006), the NCAR Whole Atmosphere Community Climate Model version 3 (WACCM3, Marsh et al. 2007), the ECHAM-5/MeSSy Atmospheric Chemistry model (EMAC, Baumgaertner et al. 2009), the KArlsruhe SImulation Model of the middle Atmosphere (KASIMA, Reddmann et al. 2010), the Canadian Middle Atmosphere Model (CMAM, Semeniuk et al. 2011), and with SOCOL (Rozanov et al. 2012). The chemistry-climate model WACCM (Marsh et al. 2007) resolves the atmosphere from the surface up to the lower thermosphere $(\sim 150 \mathrm{~km})$. WACCM uses a thermospheric ion-chemistry scheme similar to that of Jones and Rees (1973) including dissociation and dissociative ionisation of $\mathrm{N}_{2}$ and ion-chemistry formation of $\mathrm{N}$ and $\mathrm{NO}$ to consider auroral $\mathrm{N}$ and NO production, driven by a parameterised auroral electron ionisation rate. The chemistry-climate model HAMMONIA (Schmidt et al. 2006) reaches even higher up into the thermosphere (to altitudes of $\sim 400 \mathrm{~km}$ ), but does not calculate thermospheric ion chemistry explicitly in the version discussed in Schmidt et al. (2006); instead, a parameterisation of thermospheric NO formation is used which is based on observations by the SNOE instrument. KASIMA (Reddmann et al. 2010), CMAM (Semeniuk et al. 2011), ECAM-5/MeSSy (Baumgaertner et al. 2009), and SOCOL (Rozanov et al. 2012) only reach up into the upper mesosphere, so auroral NOx production cannot be included explicitly. KASIMA uses $\mathrm{NO}$ and $\mathrm{NO}_{2}$ data from the MIPAS instrument as an upper boundary condition. EMAC uses a parameterisation of mesospheric NOx as a function of the geomagnetic Ap index derived from HALOE data as an upper boundary condition; the same parameterisation is used by SOCOL. SOCOL also uses atmospheric ionisation rates derived from observed proton fluxes to account for SPEs and a parameterisation of atmospheric ionisation due to GCR based on Usoskin et al. (2010); NOx production is parameterised according to Porter et al. (1976), and the production of HOx due to atmospheric ionisation is parameterised according to Solomon et al. (1981). CMAM incorporates atmospheric ionisation rates derived from observed proton and electron fluxes and uses a parameterisation of NOx production due to atmospheric ionisation based on Porter et al. (1976); auroral NOx production above $\sim 95 \mathrm{~km}$ is not covered by CMAM. KASIMA and EMAC also can consider atmospheric ionisation in the middle atmosphere, for example, due to large solar proton events, by using parameterisations of NOx (e.g., Porter et al. 1976) and HOx (Solomon et al. 1981) production due to atmospheric ionisation (see, e.g., Baumgaertner et al. 2010; Funke et al. 2011). However, these are not used for the investigation of the EPP indirect effect.

All models reproduce downwelling of NOx into the stratosphere during winter in a realistic way. In the WACCM and HAMMONIA model runs, the impact of auroral NOx on stratospheric ozone cannot be separated from the impact of solar radiation changes, as the model runs only included time-slice experiments for solar maximum and solar minimum (Schmidt et al. 2006; Marsh et al. 2007). Transient model runs from 1960 to 2005 are carried out with the SOCOL model, but only averages of the whole period are considered, and the contributions from SPEs, auroral NOx, and GCR are not separated (Rozanov et al. 2012). In the other model studies, the impact of auroral NOx is studied separately from other changes, and a large and long-lasting ozone loss is observed at high latitudes due to the EPP indirect effect in all models. The CMAM model simulates solar maximum and solar minimum states and predicts reductions of ozone during winter (DJF in the NH, JJA in the $\mathrm{SH}$ ) due to energetic particle precipitation in the mid-stratosphere between $30-40 \mathrm{~km}$ of $30-40 \%$ in the Southern hemisphere, but only $2-5 \%$ in the Northern 
hemisphere. Total ozone loss is calculated simultaneously considering different sources of energetic particles (aurora, SPEs, and GCRs), but does not exceed $3 \%$ (Semeniuk et al. 2011). Reddmann et al. (2010) use MIPAS data from polar winter 2002/2003 to polar winter 2003/2004 as upper boundary conditions for the KASIMA model; they find the largest impact in the Northern hemisphere during the exceptional polar winter 2003/2004, when ozone losses reach up to 2-3 ppm around 35-40 km in April. However, while absolute values of ozone loss are lower (1-1.5 ppm), in the Southern winter 2003, the region of substantial ozone losses reaches to lower altitudes of $\sim 30 \mathrm{~km}$ there. Loss of total ozone is also highest in spring 2004, when it reaches more than 15 DU (about $5 \%$ considering absolute values of 300 DU). Baumgaertner et al. (2009) also consider the Antarctic winter 2003; they find ozone losses of 30-40 \% in Southern high latitudes in the altitude region 30-40 km, comparable to the results of Semeniuk et al. (2011). However, total ozone loss is estimated to be around 20-30 DU (around $10 \%$ ), considerably higher than the values of Reddmann et al. (2010) and Semeniuk et al. (2011). Only average values over the whole model experiment period from 1960 to 2005 are studied in Rozanov et al. (2012), and absolute values of ozone loss in the middle atmosphere are therefore lower than in the other model studies, amounting to $\sim 6 \%$ around $30 \mathrm{~km}$ altitude during Northern hemisphere polar winter and spring, more than $8 \%$ above $70 \mathrm{~km}$ during Northern hemisphere polar winter, more than $10 \%$ in the altitude region from 30 to $40 \mathrm{~km}$ in Southern hemisphere polar winter and spring, and more than $12 \%$ above $\sim 70 \mathrm{~km}$ altitude during Southern hemisphere winter.

To summarise, different model studies predict quite a large impact on stratospheric ozone in polar latitudes during late winter and spring, with ozone losses of 30-40\% in the altitude region of $30-40 \mathrm{~km}$ in the Southern hemisphere during years with large geomagnetic activity, more than $8 \%$ in a multi-year average from 1960 to 2005; in the Northern hemisphere, the impact is generally much smaller, with the exception of the unusual winter 2003/2004, when similar values of ozone loss are predicted.

\subsubsection{Sudden Stratospheric Warmings and the Role of Dynamics}

Large enhancements of NOx were observed in the upper stratosphere and mesosphere during polar spring at high Northern latitudes also in polar winters 2005/2006 (Randall et al. 2006; Seppälä et al. 2007b) and 2008/2009 (Randall et al. 2009; Salmi et al. 2011). During these winters, geomagnetic activity was low, and the correlation between wintertime stratospheric NOx and the Ap index discussed, for example, by Seppälä et al. (2007b) does not apply in these winters. The reason for the high NOx values appears to be, like in early 2004, the dynamical situation, with a reformation of a very strong polar vortex after a major sudden stratospheric warming (e.g., Randall et al. 2009). However, in winter $2003 / 2004$, geomagnetic activity was high, while in winter 2008/2009, geomagnetic activity was quite low, and the auroral NOx production must also have been rather low compared to winter 2003/2004. It appears that the amount of NOx transported down into the mesosphere and upper stratosphere is governed by a combination of production in the lower thermosphere, photochemical loss, and the dynamical situation. A strong, undisturbed vortex as in most Southern hemisphere winters will transport NOx down into the mid-stratosphere below $30 \mathrm{~km}$, and the amount will be determined by geomagnetic activity. Major stratospheric warmings, as occur in many winters in the Northern hemisphere, will lead to a weakening or even reversal of the downwelling in the mesosphere, and to enhanced meridional mixing by Rossby waves in the stratosphere. Therefore, in many Northern hemisphere winters, the EPP indirect effect is weak, and the signal does not 


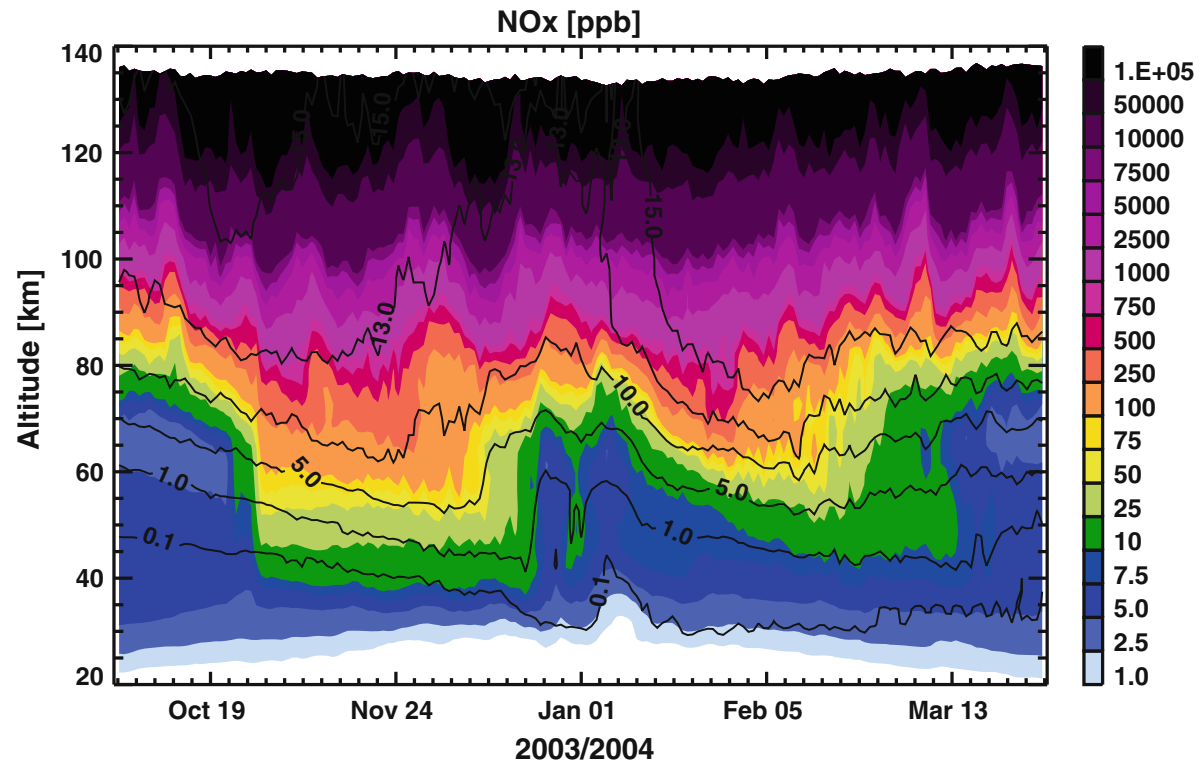

Fig. 8 Results from a three-dimensional CTM (see “Appendix 1") for Northern high latitudes $\left(70^{\circ} \mathrm{N}\right.$ zonal averages) from 1 October 2003 to 31 March 2004, showing the impact of energetic particle precipitation during this period. Coloured contours $\mathrm{NOx}\left(\mathrm{NO}+\mathrm{NO}_{2}, \mathrm{ppb}\right)$. Solid black lines isolines of $\mathrm{CO}$ (ppm), a long-lived tracer with maximal concentrations in the thermosphere, indicating thermospheric air and vertical motions. Three events can be identified: the large solar proton event on 29/30 October 2003, identified by large increases over a wide altitude range $(\sim 40-70 \mathrm{~km})$ within 1-2 days; the strong sudden stratospheric warming in late December 2003, which dilutes both NOx and CO very quickly due to mixing to lower latitudes; and the strong downwelling after the major stratospheric warming, identified by strong downward transport of both NOx and CO from altitudes above $\sim 80 \mathrm{~km}$. The impact of the downwelling after the sudden stratospheric warming on NOx in the upper stratosphere and lower mesosphere is comparable to the large solar event. Qualitatively, these results agree very well with observations. However, while the amount of NOx produced by the solar particle event is in reasonable agreement with observations in the stratosphere and lower mesosphere (see, for example, Funke et al. 2011), the amount of NOx transported down after the strong warming is underestimated by the model quite considerably (see, for example, Lopez-Puertas et al. 2006 and Sinnhuber et al. 2012)

progress into the stratosphere. However, after exceptional warming events as in Northern hemisphere winters 2003/2004, 2005/2006, and 2008/2009, the vortex re-forms strongly, becoming comparable to its Southern hemisphere counterpart. Then, the EPP indirect effect in the Northern hemisphere can be comparable to or even larger than in the Southern hemisphere, probably due to unusually strong descent in the middle atmosphere in the newly reformed polar vortex after the unusual major warming event (e.g., Randall et al. 2009; Smith 2012).

In Fig. 8, model results from the 3D CTM (see "Appendix 1") are shown for Northern hemisphere high latitudes in Arctic winter 2003/2004. The model is driven with temperatures and wind fields from the LIMA model (Berger 2008). Both the dilution of NOx and $\mathrm{CO}$ in the upper stratosphere and lower mesosphere during the major warming event in December 2003 and the renewed downward transport of NOx and CO after the major warming event in January and February 2004 are well reproduced. However, NOx values in the lower mesosphere and stratosphere in late winter and spring are nearly an order of magnitude lower than observed values as shown, for example, by Lopez-Puertas et al. 
(2006) and Seppälä et al. (2007a). There are two possible sources for the underestimation of the NOx values: (1) a problem with the parameterisation of NOx formation by ion chemistry in the upper mesosphere/lower thermosphere; the model uses a parameterisation of NOx production based on Porter et al. (1976) and Rusch et al. (1981), which underestimates NOx production in the upper mesosphere and lower thermosphere (see Sect. 2.2.2); this, however, could explain a difference of a factor 2 at most. Uncertainties in the partitioning between $\mathrm{N}$ and $\mathrm{N}^{*}$ from $\mathrm{N}_{2}$ dissociation and dissociative ionisation, which affects the effective NOx production (see Sect. 2.2.3) as well as an underestimation of ionisation rates in the upper mesosphere/lower thermosphere, could also contribute. (2) Problems in the representation of transport and mixing, as, for example, in the resolved wind fields of the LIMA model after the warming event, or in molecular and eddy diffusive transport across the mesopause. One reason for the latter may be that CTMs do not consider direct mixing by gravity waves, which has been shown to induce significant down-gradient fluxes of minor constituents across the mesopause (e.g., Grygalashvyly et al. 2012; Smith 2012). From the observation database available at this time, it is not possible to distinguish whether the underestimation is due to chemistry or dynamics, as no mesospheric observations are available above $\sim 70 \mathrm{~km}$, the highest tangent altitude of MIPAS.

In the paper by Solomon et al. (1982), it was noted that 'the greatest uncertainties lie in the parameterisation of transport processes and in the $\mathrm{N}\left({ }^{2} \mathrm{D}\right)$ production branching ratio'; the main uncertainties are apparently still the same.

\subsubsection{EPP Indirect Effect of Large Solar Particle Events and a Comparison of Source Strengths}

Solar particle events, even those with very hard spectra, that is, with large fluxes of very high-energetic protons that can precipitate down into the lower stratosphere, produce significant amounts of NOx only at altitudes above $\sim 40 \mathrm{~km}$ (Seppälä et al. 2008). This NOx can be transported down into the lower stratosphere during polar winter, equivalent to the EPP indirect effect discussed for auroral NOx in Sect. 3.1.1; however, it is expected that SPE NOx will proceed lower down into the stratosphere than auroral NOx, to altitudes well below $30 \mathrm{~km}$ as the source region is at considerably lower altitudes as shown in several model studies by Jackman et al. (2000, 2005a, b, 2009).

Enhanced values of NOx have been observed in the Southern mid-stratosphere around $32 \mathrm{~km}$ several weeks after the large solar particle event of 14 July 2000 (Randall et al. 2001). These enhanced values can be explained very well as a result of NOx production during the particle event in the upper stratosphere and mesosphere, and subsequent downward transport during polar winter (e.g., Sinnhuber et al. 2004).

The impact of energetic particle precipitation on the NOx budget of the middle atmosphere has been assessed in a number of studies. It was estimated that photolysis and oxidation of $\mathrm{N}_{2} \mathrm{O}$ yields 51-58 GMol of NOy per year globally (e.g., Vitt and Jackman 1996); GCR also produce NOx mostly in the stratosphere (Nicolet 1975), with a global production of 5-6.1 GMol per year estimated (Vitt and Jackman 1996), that is, about $10 \%$ of the amount produced by photolysis of $\mathrm{N}_{2} \mathrm{O}$. SPEs provide a very variable and sporadic source of NOx; the NOy production due to very large SPEs in the middle atmosphere is estimated to several GMol globally (e.g., Crutzen 1975; Vitt and Jackman 1996; Jackman et al. 2005b, 2009). The largest values have been estimated based on ionisation rates derived from observed proton fluxes for the solar particle event of October 1989 [13.9 GMol globally, Vitt and Jackman (1996)], the series of particle events in October/ 
November 2003 [6.0 GMol globally, Jackman et al. (2009)], and the solar proton event of July 2000 [5.8 GMol globally, Jackman et al. (2009)]. Based on observations of NOy, the impact of the particle events in October/November 2003 was estimated much smaller [1.5 GMol, Reddmann et al. (2010)], possibly because the estimates of Jackman et al. (2009) based on the gross NOy production rate do not consider chemical loss processes and therefore provide an upper limit of the net NOy production. The impact of thermospheric NOx from the aurora has been estimated mainly based on observations; a large inter-annual variability is observed with total NOy transported into one hemisphere during a polar winter ranging from 0 to $2.6 \mathrm{GMol}$ depending on geomagnetic activity and the dynamical situation [e.g., Siskind et al. (2000); Funke et al. (2005), Randall et al. (2007); Reddmann et al. (2010)]. The largest values have been estimated for Northern hemisphere winter 2003/2004 (2 GMol, Reddmann et al. (2010), Southern hemisphere winter 2003 [1.1 GMol (Randall et al. 2007; Funke et al. 2005); 1.4 GMol (Reddmann et al. 2010)], and Southern hemisphere winter 1994 (0.7 GMol, Randall et al. 2007). The different estimates for the contributions to the NOy budget of the middle atmosphere are summarised in Table 2.

As with the EPP indirect effect, the downward transport of enhanced NOx due to SPEs into the stratosphere is expected to cause long-lasting loss of stratospheric ozone in polar latitudes (e.g., Crutzen 1975), but this is difficult to quantify from observations due to the strong variability of stratospheric ozone. This has been investigated in a number of model

Table 2 Estimates of global or hemispheric production of $\mathrm{NOy}\left(\mathrm{NOx}+\mathrm{HNO}_{3}+\mathrm{HNO}_{4}+\mathrm{ClON}-\right.$ $\mathrm{O}_{2}+\mathrm{BrONO}_{2}+2 \mathrm{~N}_{2} \mathrm{O}_{5}$ ) for different energetic particle precipitation events or sources, for example, solar particle events, galactic cosmic rays, the aurora), compared to $\mathrm{N}_{2} \mathrm{O}$ oxidation

\begin{tabular}{|c|c|c|c|c|c|}
\hline $\begin{array}{l}\text { Solar particle events } \\
\text { (GMol/event) }\end{array}$ & $\begin{array}{l}\text { Thermosphere } \\
\text { (aurora) (GMol/ } \\
\text { winter) }\end{array}$ & $\begin{array}{l}\text { Galactic } \\
\text { cosmic rays } \\
\text { (GMol/year) }\end{array}$ & $\begin{array}{l}\mathrm{N}_{2} \mathrm{O} \\
\text { oxidation } \\
\text { (GMol/ } \\
\text { year) }\end{array}$ & Source & Reference \\
\hline $0.85-8.47$ & & & & Ionisation rates & $\begin{array}{r}\text { Crutzen } \\
(1975)\end{array}$ \\
\hline $\begin{array}{l}0.02-13.9 \text { maximum } \\
1989\end{array}$ & & $5.0-6.1$ & $51-58$ & Ionisation rates & $\begin{array}{l}\text { Vitt and } \\
\text { Jackman } \\
(1996)\end{array}$ \\
\hline $\begin{array}{l}1.99-11.1 \text { maximum } \\
1989\end{array}$ & & & & Ionisation rates & $\begin{array}{l}\text { Jackman } \\
\text { et al. } \\
(2005 b)\end{array}$ \\
\hline \multirow[t]{4}{*}{$\begin{array}{l}\text { 0.9-6.0 maximum } \\
2003 \text { (does not } \\
\text { include 1989) }\end{array}$} & & & & Ionisation rates & $\begin{array}{c}\text { Jackman } \\
\text { et al. } \\
2009\end{array}$ \\
\hline & $\begin{array}{l}0.8-1.3 \\
\text { Maximum: } \\
\text { SH } 1991\end{array}$ & & & $\begin{array}{l}\text { HALOE } \\
\text { observations }\end{array}$ & $\begin{array}{l}\text { Siskind } \\
\text { et al. } \\
(2000)\end{array}$ \\
\hline & 1.1 SH 2003 & & & $\begin{array}{l}\text { MIPAS } \\
\text { observations }\end{array}$ & $\begin{array}{l}\text { Funke et al. } \\
\text { (2005) }\end{array}$ \\
\hline & $\begin{array}{l}\text { 0-1.1 } \\
\text { Maximum: } \\
\text { SH } 1994\end{array}$ & & & $\begin{array}{c}\text { HALOE, ACE } \\
\text { and POAM } \\
\text { observations }\end{array}$ & $\begin{array}{l}\text { Randall } \\
\text { et al. } \\
(2007)\end{array}$ \\
\hline $1.5(2003)$ & $\begin{array}{l}0.4 \mathrm{NH} 2002 / \\
2003 \\
1.5 \mathrm{NH} \text { early } \\
2004\end{array}$ & & & $\begin{array}{l}\text { MIPAS } \\
\text { observations } \\
\text { with KASIMA } \\
\text { model }\end{array}$ & $\begin{array}{l}\text { Reddmann } \\
\text { et al. } \\
(2010)\end{array}$ \\
\hline
\end{tabular}


studies for different large solar proton events between 1960 and the present; models predict ozone losses of more than $10 \%$ in the region 30-40 km (more than $20 \%$ in the SH during 2000, e.g., Jackman et al. (2009)], of several per cent down to altitudes below $30 \mathrm{~km}$ lasting for several months after the SPE [e.g., Jackman et al. 2000, 2005a, b, 2009), but the impact on total ozone is low-less than $3 \%$ even for the very large events in 1989, 2000, and 2003 (Jackman et al. 2000, 2005a, b, 2009) probably because below $\sim 30 \mathrm{~km}$, enhanced NOx values can lead to enhanced formation of the chlorine and bromine reservoir species $\mathrm{ClONO}_{2}$ and $\mathrm{BrONO}_{2}$, slowing down the 'ozone hole' formation chemistry in cold polar winters (Jackman et al., 2000).

Comparing the estimates for the impact of large SPEs with the EPP indirect effect discussed in Sects. 3.1.1.-3.1.3, very large SPEs appear to have a larger impact on the stratospheric NOy budget (see Table 2), but a smaller impact on the ozone loss, both in the altitude region around $30-40 \mathrm{~km}$, and on total ozone.

\subsection{Coupling to Atmospheric Dynamics}

Energetic particle precipitation can have an impact on atmospheric dynamics by changing atmospheric heating and cooling rates. There are several processes during and after the particle events which can affect heating/cooling in the mesosphere and lower thermosphere: directly due to Joule dissipation between the ambient electric fields and the electron or ion currents (so-called Joule heating) or due to the energy dissipation of the precipitating particles (particle heating), or indirectly due to changes in the chemical composition, which may change the chemical heating rate due to exothermic reactions (chemical heating) or the radiative heating and cooling rates. Also, changes in the electron density will affect the ion drag and therefore directly affect neutral winds.

\subsubsection{Joule Heating}

Joule heating is due to energy dissipation of charged particles moving in an electric field; the heating rate is given by the current density $\vec{j}$ and the electric field $\vec{E}$. In the atmosphere, the current is provided by electrons and ions moving in the effective field $\vec{E}^{\prime}=\vec{E}+\vec{v} \times \vec{B}$ (Banks 1979):

$$
\partial Q=\vec{j} \cdot(\vec{E}+\vec{v} \times \vec{B})
$$

where $\partial Q$ is the Joule energy dissipation rate, $\vec{v}$ is the neutral wind speed, $\vec{E}$ is the ordinary electric field, and $\vec{B}$ the geomagnetic field. If the contribution of the neutral wind speed is small, the energy dissipation rate can be expressed as

$$
\partial Q=\frac{e \cdot\left[\mathrm{N}_{e}\right]}{B} E^{2}\left(\frac{v_{i n} \omega_{i}}{v_{i n}^{2}+\omega_{i}^{2}}+\frac{v_{e n} \omega_{e}}{v_{e n}^{2}+\omega_{e}^{2}}\right)
$$

where $\mathrm{N}_{e}$ is the electron density, $e$ the electron charge, the $v$ 's are the collision frequencies between neutrals and electrons respectively ions, and the $\varpi$ 's are the Larmor frequencies of ions respectively electrons (Banks 1979). Thus, the Joule heating rate depends critically on the electron density, the electric field, and the relation of collision frequencies to Larmor frequencies, which is maximal in the upper mesosphere around $70 \mathrm{~km}$ for electrons, in the lower thermosphere around 120-130 km for ions (Banks 
1979). Joule heating is a permanent feature of the aurora and is strongest in the auroral region because there electric fields are largest (e.g., Banks 1979; Roble et al. 1987). It increases during geomagnetic storms and strong aurora events and can reach values of several K/day in the upper mesosphere during strong SPEs (e.g., Banks 1979; Roble et al. 1987), increasing to several $100 \mathrm{~K} /$ day in the auroral zone above $\sim 120 \mathrm{~km}$ (e.g., Roble et al. 1987). The Joule heating rate has been calculated exemplarily for the period of the main proton forcing during the October/November 2003 solar storm (28-30 October 2003) using electron and ion densities from the UBIC model and two different electric field strengths based on Banks (1979), that is, Reaction R-24. The collision frequencies were taken from Banks and Kockarts (1973), for a temperature of $300 \mathrm{~K}$. Results for an electric field strength of $100 \mathrm{mV} / \mathrm{m}$ as typical for the dayside aurora (Banks 1979) agree quite well qualitatively with the estimates of Banks (1979), Roble et al. (1987), and Wilson et al. (2006), see Fig. 9. However, they are about an order of magnitude larger than the zonally averaged Joule heating rates shown by Jackman et al. (2007) for the same solar storm; because the electric fields are very variable even within the aurora, Joule heating is very variable locally (e.g., Banks 1979; Zhang et al. 2005; Kosch et al. 2011), and zonally averaged values are much lower than values within the aurora. Results for an electric field strength of $20 \mathrm{mV} / \mathrm{m}$ as a more likely estimate of the polar cap region (Banks 1979) show values similar to those obtained by Jackman et al. (2007). So it appears that Joule heating can be very variable over polar regions even during large solar storms. This is also discussed by Jackman et al. (2007):

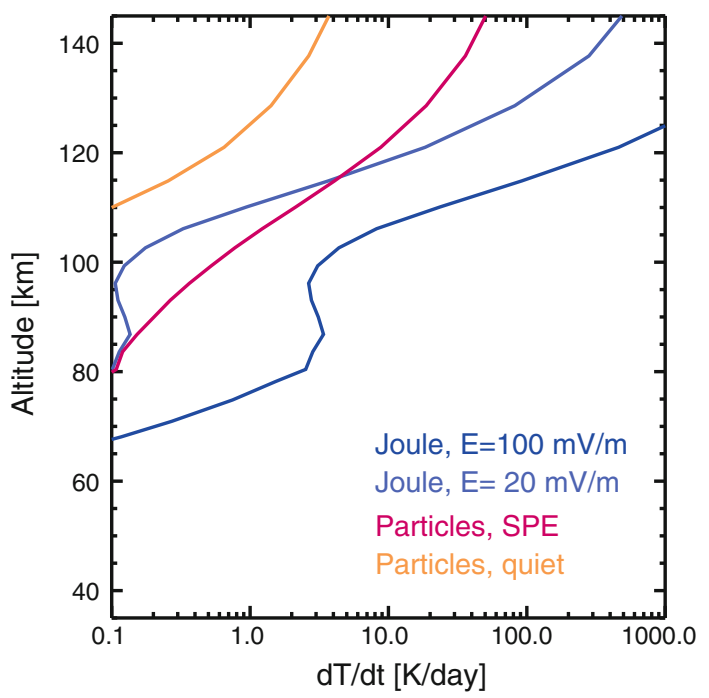

Fig. 9 Calculation of the Joule and particle heating rates as a function of altitude during the large solar particle event on 28-30 October 2003. Joule heating was calculated based on R-25 using electron densities from the UBIC model (see "Appendix 2"), a magnetic field strength of $5 \times 10^{-5}$ T from Banks (1979), collision frequencies from Banks and Kockarts (1973), and two electric field strength: $20 \mathrm{mV} / \mathrm{m}$ (light blue line) and $100 \mathrm{mV} / \mathrm{m}$ (dark blue line); $100 \mathrm{mV} / \mathrm{m}$ are values typical for the dayside auroral oval (Banks 1979). Particle heating rates are an upper estimate assuming that all energy is transferred into heat (i.e. $35.5 \mathrm{eV} *$ ion pair production rate), using mean ionisation rates for 28-30 October 2003 within the auroral zone $\left(70^{\circ} \mathrm{N} / 180^{\circ} \mathrm{E}\right.$, dark red line), and for 26-28 October 2003 (orange line). Joule heating rates for 26-28 October 2003 are well below $0.1 \mathrm{~K} /$ day for all altitudes 
Our computation of Joule heating ... indicate a very large thermospheric contribution and a fairly significant mesospheric contribution at certain times and locations within the polar cap regions $\left(>60^{\circ}\right.$ geomagnetic latitude). However, the net zonal average contribution of SPE-induced Joule heating to total mesospheric heating appears to be small.

\subsubsection{Particle Heating}

Particle heating is due to the energy loss of precipitating energetic particles and their secondary electrons. However, it is not clear how much of the energy will be transferred into heat; a considerable amount of the energy will go into dissociation, dissociative ionisation, and ionisation of the ambient atmosphere (see Sect. 2.2.1); or into excitation of the ambient atmosphere, which may contribute to heating, but also to the auroral airglow and therefore a radiative cooling of the atmosphere. On the other hand, the chemical changes due to particle precipitation can lead to exothermic chemical reactions (e.g., chemical heating), which can also contribute to heating of the lower thermosphere (e.g., Rees et al. 1983). A simple estimate of an absolute upper limit of the heating capacity due to energetic particle precipitation can be made by assuming that all energy is transferred into heat, thus that about $35 \mathrm{eV}$ are transmitted per ion pair. This has been calculated for the large solar event of October 2003 to compare to the contribution of Joule heating (see Fig. 9). Shown are heating rates based on AIMOS ionisation rates for the period of the largest proton forcing (28-30 October 2003) within the auroral zone $\left(70^{\circ} \mathrm{N} / 180^{\circ} \mathrm{E}\right)$ and for a reference period 2 days previous (26-28 October 2003, ionisation rates are shown in Panel B of Fig. 5). As can be seen, the upper estimate for the particle heating rate is of the same order of magnitude to the Joule heating, but below $1 \mathrm{~K} /$ day below $\sim 100 \mathrm{~km}$; in the lower thermosphere, the contribution increases to several K/day. However, it should be pointed out that this is really only an upper estimate; in reality, a significant proportion of the energy will not be transferred to heat locally, but will be transferred to the secondary particles, or to chemical potential energy which may be transported far from its source region, or into excitation of atoms or molecules, which may lead to airglow emissions and an effective radiative cooling. This is discussed, for example, by Roble (1995) for photoionisation in the lower thermosphere; he estimates that about 30-40\% of the photon energy will be transferred into heat directly for a $30 \mathrm{eV}$ solar EUV photon. Similar processes should play a role for particle impact ionisation. Qualitatively this is in good agreement with earlier studies showing that particle heating is generally lower than Joule heating, but can reach similar orders of magnitude during large geomagnetic disturbances in the thermosphere (Banks 1977; Kopp et al. 1985; Wilson et al. 2006). Both Joule and particle heating must be considered in the lower thermosphere, but considering that the estimate given in Fig. 9 for a very large disturbance gives an absolute upper limit, and the true contribution is likely much smaller (e.g., Banks 1977; Kopp et al. 1985), the contribution of particle heating to the mesospheric heat budget appears to be negligible.

\subsubsection{Chemical Heating}

Chemical heating is due to the energy release from exothermic chemical reactions. This has been discussed as a significant heat source in the mesosphere due to reactions of $\mathrm{Ox}$ and HOx species (e.g., Mlynczak and Solomon 1991, 1993) and for the lower thermosphere due to reactions of atomic nitrogen, both in the ground and excited states, as well as for some ion-chemistry and quenching reactions (e.g., Rees et al. 1983). Heating due 
to $\mathrm{Ox}$ and HOx species can reach several $\mathrm{K} /$ day in the mesosphere with maximal values around the mesopause and in the lower thermosphere (Mlynczak and Solomon 1991); however, some of the energy will also be emitted from excited states of the products (e.g., Mlynczak and Solomon 1993) and therefore not contribute to heating of the mesosphere. Both $\mathrm{Ox}$ and $\mathrm{HOx}$ species will change their composition due to energetic particle precipitation (see Sects. 2.2-2.4) therefore changing the chemical heating rates; but, as the amount of HOx increases, then the amount of Ox is likely to decrease, so that it is not immediately clear whether chemical heating rates will increase or decrease due to energetic particle precipitation in the mesosphere. In the thermosphere, chemical heating will likely increase due to the production of $\mathrm{N}$ and $\mathrm{N}^{*}$ and the increased ionisation (e.g., Rees et al. 1983).

As trace gases are transported and mixed throughout the atmosphere, potential chemical energy can be transported along with them if their photochemical lifetime is long enough. Thus, atomic oxygen produced by ionisation due to energetic particles or by photo-dissociation in the lower thermosphere can be transported down into the upper mesosphere and release heat there by the recombination reaction (Rees 1989):

$$
\mathrm{O}+\mathrm{O}+\mathrm{M} \rightarrow \mathrm{O}_{2}+\mathrm{M}+5.12 \mathrm{eV}
$$

\subsubsection{Radiative Heating and Cooling}

Radiative heating due to absorption by $\mathrm{O}_{3}$ and $\mathrm{O}_{2}$ is among the most efficient heating mechanism for the middle atmosphere (e.g., Mlynczak and Solomon 1993, see also Feofilov and Kutepov 2012). Ozone is especially important in the stratosphere and lower mesosphere; thus, the long-lasting ozone loss following large energetic particle precipitation events or the downwelling of thermospheric air into the mesosphere and stratosphere (see Sects. 3.1.2 and 3.1.4) will likely lead to long-lasting cooling of the stratosphere and lower mesosphere due to decreased solar heating by ozone.

In the thermosphere, NO is one of the main contributors to IR cooling (Feofilov and Kutepov 2012). As NO increases significantly due to energetic particle precipitationdirectly due to dissociation, dissociative ionisation, and ionisation below $\sim 150 \mathrm{~km}$ (see Sect. 2.1), indirectly as a result of Joule heating above $\sim 150 \mathrm{~km}$ (e.g., Dobbin and Aylward 2008; Barth et al. 2009; Barth 2010) — the thermosphere is also cooled efficiently, with NO acting as a 'thermostat' of the lower thermosphere (e.g., Mlynczak et al. 2005, 2008, 2010; Qian et al. 2010; Lu et al. 2010).

\subsubsection{Thermospheric Response to Energetic Particle Precipitation}

In the thermosphere, enhanced geomagnetic activity will lead to enhanced temperatures both due to Joule and particle heating. This has implication as well for the dynamics of the lower thermosphere, which responds in several ways. The enhanced heating of the lower thermosphere leads to enhanced vertical wind speeds in the auroral region, that is, upwelling, in the lower thermosphere (e.g., Price and Jacka 1991) as well as to increased horizontal wind speeds (Price et al. 1991). Meridional winds are accelerated equatorwards (e.g., Barth et al. 2009), and gravity waves produced by the Joule heating can also propagate equatorwards (e.g., Barth et al. 2009; Barth 2010). 


\subsubsection{The Response of Mesospheric Dynamics to Large Energetic Particle Precipitation Events}

The response of temperatures and dynamics to energetic particle precipitation or geomagnetic disturbances and the aurora in the mesosphere is not as clear as the thermospheric response. Particle heating is probably negligible, the impact of chemical heating is unclear, and heating due to Joule dissipation, which may be quite significant, competes with decreased radiative heating due to the ozone loss. Observations and model studies of the response of mesospheric temperatures and dynamics give an ambiguous picture.

Jackman et al. (2007) investigated changes in atmospheric heating and cooling rates and atmospheric temperatures due to the different mechanism in the mesosphere during the solar event of October/November 2003 using a general circulation model and found only small changes; a maximal cooling of up to $1 \mathrm{~K}$ per day in the lower mesosphere, a heating of more than $1.5 \mathrm{~K}$ per day in the upper mesosphere, primarily due to adiabatic heating in the Southern hemisphere, resulting in temperature changes of less than $3 \mathrm{~K}$. The impact of Joule heating was found to be negligible in the zonal average. A similar model study for a longer time series from 1963 to 2005 using a chemistry-climate model shows temperature variations in the order of magnitude of $\pm 10 \mathrm{~K}$ due to large SPEs in the stratosphere and mesosphere lasting for several months after the events, but only a small statistically significant responses of the temperature (Jackman et al. 2009). In contrast to these model results, much larger increases in temperatures of 10-15 K were observed during two large SPEs in the upper mesosphere, during the July 2000 event in the Northern hemisphere as observed by the HALOE instrument (Krivolutsky et al. 2006), and during the January 2005 solar particle event in the Southern hemisphere by MLS/AURA (von Savigny et al. 2007). During the January 2005 solar particle event, a decrease in the noctilucent cloud cover was observed in the Southern summer hemisphere mesopause; a similar response has been observed earlier, correlating geomagnetic activity with a decrease in noctilucent clouds, which was interpreted as probably due to Joule heating (D'Angelo and Ungstrup 1976). However, it was shown in a model study using a mechanistic model of the middle atmosphere dynamics that the observed temperature increases at the summer mesopause during January 2005 can be explained as a result of a complex coupling between radiative heating rate changes due to the ozone loss in the lower mesosphere, the mean circulation, and gravity wave propagation and breaking throughout the mesosphere, transporting the signal from the lower mesosphere to the mesopause (Becker and von Savigny 2010), similar to the July 2000 event as shown by Krivolutsky et al. (2006). In contrast to that, a statistical study of the temperature response to geomagnetic activity in 2003 based on temperature data from the SABER instrument onboard the TIMED satellite has shown no statistically significant response on a daily average basis in the mesosphere, but a statistically significant cooling during night-time at high latitudes in 85-90 km altitude for high values of the $\mathrm{Kp}$ index, which is interpreted most likely to be a response to either chemical heating rate changes or adiabatic cooling due to increased upwelling (Tyssoy et al. 2010), the reverse response than observed in the sunlit summer hemisphere (e.g., Krivolutsky et al. 2006; von Savigny et al. 2007; Becker and von Savigny 2010).

\subsubsection{The Response of Stratospheric and Tropospheric Dynamics to Enhanced Geomagnetic Activity}

There are several investigations correlating temperatures and dynamics of the atmosphere below the MLT region with the Ap index, that is, with geomagnetic activity, which 
primarily affects the chemical composition of the upper mesosphere and lower thermosphere. The working hypothesis is that high geomagnetic activity leads to high values of NOx in the MLT region, which can be transported down into the stratosphere during polar winter and then lead to loss of stratospheric ozone (see Sect. 3.1). This in turn can lead to an effective cooling of the sunlit stratosphere due to lower radiative heating by ozone, to an effective heating in the absence of sunlight during polar night, instigating changes of the atmospheric dynamics which also include interactions between gravity wave propagation and the zonal mean zonal winds.

Lu et al. (2008a) investigated 40 years of stratospheric temperatures and wind field data and found a good correlation between temperatures in the stratosphere and the Ap index in late winter and spring for years without sudden stratospheric warmings and not affected by volcanic eruptions, but only during years of low solar activity. While the correlation found by Lu et al. (2008a) between temperature and Ap index appears to be quite robust, the sign is positive, so the primary effect is not cooling due to enhanced loss of stratospheric ozone outside the polar night. A recent model study using a three-dimensional global chemistryclimate model considering auroral NOx, large SPEs, and GCR (Rozanov et al. 2012, see also Sect. 3.1.2) found only small impact onto stratospheric temperatures compared to a model run without energetic particle precipitation, with significant differences of less than $0.5 \mathrm{~K}$ restricted to altitudes around $30 \mathrm{~km}$ during polar summer $\left(\mathrm{JJA}, 60^{\circ} \mathrm{N}-90^{\circ} \mathrm{N}\right.$ average). In the model study, the derived temperature differences are negative, that is, showing a cooling as expected from stratospheric ozone loss, but in contrast to the observations of $\mathrm{Lu}$ et al. (2008a). It appears that the mechanism leading to temperature changes is more complex, and not yet completely understood.

A similar investigation by $\mathrm{Lu}$ and co-authors correlates solar wind pressure with zonal mean zonal wind and the Northern annular mode (NAM, see, e.g., Baldwin and Dunkerton 1999) index in Northern hemisphere winter and spring (Lu et al. 2008b). They found an increase in vortex strength (i.e. a positive anomaly of the NAM index) for high solar wind pressure, which progresses all the way down to the surface during solar maximum as a consequence of the combined effects of high solar wind pressure and high solar radiation (see also Kodera and Kuroda 2005). During solar minimum, the impact is restricted to the stratosphere. This suggests a combination of different solar signals amplifying each other, and which cause refracting/redistribution of upward propagating wave signals and thus projection of the solar signal to the NAM index. The mechanism is as yet not really understood, but suggests that the impact of energetic particle precipitation into the MLT region could progress all the way down to the surface. This was investigated by a number of model studies using chemistry-climate models including an additional NOx source into the upper boundary (e.g., Langematz et al. 2005; Rozanov et al. 2005, 2012; Baumgaertner et al. 2011). Langematz et al. (2005) only considered stratospheric changes; Rozanov et al. (2005, 2012) and Baumgaertner et al. (2011) also investigated surface air temperature changes during polar winter and found an impact on surface temperatures with a NAM-like pattern of temperature anomalies during Northern hemisphere winter; Baumgaertner et al. (2011) also showed in their model that the source of the tropospheric anomaly are indeed anomalies in the stratospheric NAM index which progress down into the troposphere, a similar mechanism to that postulated by Kodera and Kuroda (2005) for a solar signal. The response of the Southern hemisphere surface air temperature during winter was also investigated by Baumgaertner et al. (2011), showing a pattern of significant cooling across Antarctica, and warming in the Antarctic Peninsula.

A similar signal of surface temperature anomalies as predicted by the model results was observed in 40 years of temperature data by Seppälä et al. (2009); they showed that years 
with a high Ap index likely have warmer winters in Northern Europe, colder winters, for example, over Greenland, than years with low Ap index. A similar response was found in the Southern hemisphere during winter, with warmer winters in the Antarctic Peninsula during years with high Ap index, colder winters on the Antarctic continent. This suggests that precipitation of energetic particles into the MLT region indeed can have an impact on the temperatures and dynamics of the whole atmosphere at least during polar winter, when coupling from the middle atmosphere to the lower atmosphere is possible (Baldwin and Dunkerton 1999; Lee et al. 2009), though newer investigations suggest that the dependency of the NAM which progresses the signal from the middle atmosphere to the troposphere is strongly nonlinear and also depends on the solar modulation (Li et al. 2011).

\section{Summary: Open Questions}

Energetic particle precipitation can change the chemical composition of the MLT region quite considerably. The most important processes are dissociation, dissociative ionisation, and ionisation of $\mathrm{N}_{2}, \mathrm{O}_{2}$, and $\mathrm{O}$, subsequent ion-chemistry formation of $\mathrm{NOx}$ and HOx, and subsequent ozone loss. Atmospheric dynamics can also be affected, in the thermosphere mainly by Joule and particle heating and responding upwelling and gravity wave production, in the mesosphere by a combination of Joule heating, changes in chemical and radiative heating, and a complex coupling to atmospheric dynamics involving changes in the zonal mean zonal flow, gravity wave propagation and breaking. During polar winter, NOx produced by energetic particle precipitation can be transported from the lower thermosphere and mesosphere down into the stratosphere, where it effectively destroys ozone. Large solar proton events can have a quite significant but very sporadic impact on the stratospheric NOx budget; downward propagation of auroral NO can have a slightly smaller, but comparable impact especially in the Southern hemisphere during years of large geomagnetic activity, or in the Northern hemisphere after strong sudden stratospheric warmings. There is evidence both from observations and from model studies that geomagnetic activity can also have an impact on atmospheric dynamics down to the surface during polar winter and spring; this would contribute to the interaction between solar activity (which modulates geomagnetic activity) and the climate system. However, in this chain of processes, many questions are still open. The most important are the partitioning between ground-state $\mathrm{N}$ and the excited states in the primary dissociation of $\mathrm{N}_{2}$, the impact of the dynamical variability of the middle atmosphere onto the EPP indirect effect, which provides a large interannual variability especially in the Northern hemisphere, and the complex coupling between chemical changes, heating and cooling rate changes, and atmospheric temperatures and dynamics especially in the mesosphere.

Acknowledgments The authors like to thank J.-M. Wissing and M.-B. Kallenrode, University of Osnabrück, for the AIMOS data, U. Berger, IAP Kühlungsborn, for the LIMA model data, and D. Marsh and A. Smith for the WACCM data. M. Sinnhuber gratefully acknowledges funding by the Helmholtz-Society within the Helmholtz Young Investigators group 'Solar variability, climate, and the role of the mesosphere/ lower thermosphere', project NWG-642.

Open Access This article is distributed under the terms of the Creative Commons Attribution License which permits any use, distribution, and reproduction in any medium, provided the original author(s) and the source are credited. 


\section{Appendix: Models Used}

\section{Appendix 1: Three-Dimensional CTM}

The three-dimensional chemistry and transport (3dCTM) model is a further development of the Bremen 3d CTM [see, for example, Wissing et al. (2010); Funke et al. (2011)], a combination of the stratospheric transport model as described in Sinnhuber et al. (2003) and the chemistry code of the two-dimensional model of the stratosphere and mesosphere, as described in, for example, Sinnhuber et al. (2003a) and Winkler et al. (2008), which is based on the chemistry code of the SLIMCAT model (Chipperfield 1999). Advection is calculated using the second-order moments scheme by Prather (1986). The model version used here runs on isobaric surfaces from the tropopause into the lower thermosphere. The vertical flux is calculated by vertical wind fields as provided in the meteorological data. The horizontal resolution is the same in all model versions and thus $3.75^{\circ}$ in longitude and about $2.5^{\circ}$ in latitude. In the stratosphere, a family approach is used for the following chemical families: $\mathrm{Ox}\left(\mathrm{O}, \mathrm{O}\left({ }^{1} \mathrm{D}\right), \mathrm{O}_{3}\right)$, $\mathrm{NOx}\left(\mathrm{N}, \mathrm{NO}, \mathrm{NO}_{2}\right), \mathrm{HOx}\left(\mathrm{H}, \mathrm{OH}, \mathrm{HO}_{2}\right), \mathrm{BrOx}(\mathrm{Br}$, $\mathrm{BrO}$ ), $\mathrm{ClOx}\left(\mathrm{Cl}, \mathrm{ClO}, 2 \mathrm{Cl}_{2} \mathrm{O}_{2}\right)$, and $\mathrm{CHOx}\left(\mathrm{CH}_{3}, \mathrm{CH}_{3} \mathrm{O}_{2}, \mathrm{CH}_{3} \mathrm{OOH}, \mathrm{CH}_{3} \mathrm{O}, \mathrm{HCO}\right)$; in the mesosphere and lower thermosphere above $0.33 \mathrm{hPa}(\sim 50 \mathrm{~km})$, the family approach is not used for Ox and NOx. To simulate the impact of precipitating particles, ionisation rates provided by the Atmospheric Ionisation Module Osnabrück (AIMOS) (Wissing and Kallenrode 2009) are implemented in all model versions. The impact of this ionisation is considered by using a simple parametrisation. Per ion pair $1.25 \mathrm{NOx}(55 \% \mathrm{NO}$, and $45 \%$ N (Rusch et al. 1981), up to 2 HOx compounds (Solomon et al. 1981) and 1.15 O (Porter et al. 1976) are formed.

The results presented in this review paper as presented in Figs. 2 and 8 are taken from a model simulation driven by meteorological data provided by the three-dimensional dynamical model LIMA (Berger 2008) that runs on 37 isobaric levels, from about 250 to $5 \times 10^{-6} \mathrm{hPa}$ (about $10-140 \mathrm{~km}$ ). The simulation has been initialised on 1 January 2002 from a multi-year two-dimensional model spin-up run and has been continued until the end of 2009. The model simulation includes ionisation due to both protons and electron events as prescribed by ionisation rates provided by the AIMOS model. To calculate the difference to an undisturbed scenario, an additional base simulation has been carried out without consideration of any ionisation effects by precipitating particles. The model has been extended into the lower thermosphere only recently and does not yet include a variable $\mathrm{H}_{2}$ and $\mathrm{O}_{2}$ distribution. Thus, the partitioning of $\mathrm{HOx}$ deviates from more realistic values above ca. $80 \mathrm{~km}$, as do night-time ozone values, which are driven by HOx. Therefore, only results from NOx produced due to energetic particle precipitation are shown here.

\section{Appendix 2: UBIC}

The University of Bremen Ion Chemistry model UBIC is a one-dimensional column model of ion-chemistry optimised for the stratosphere and mesosphere. UBIC considers 55 positive, 49 negative, and 33 neutral species. Ionisation is driven by prescribed ionisation rates and by photo-ionisation of NO. The model includes about 600 ion-neutral, ion-ion, and neutral-neutral reactions as well as photoelectron detachment and photo-dissociation. The primary positive charge is distributed onto $\mathrm{N}_{2}, \mathrm{~N}, \mathrm{O}_{2}$, and $\mathrm{O}$ and is balanced with electrons. Ionisation rates of the primary ions are calculated using ionisation cross sections from Rusch et al. (1981) and Jones and Rees (1973). The production of N and O due to dissociation and dissociative ionisation is implemented according to the lower limit of 
Table 3 Primary ion formation rates

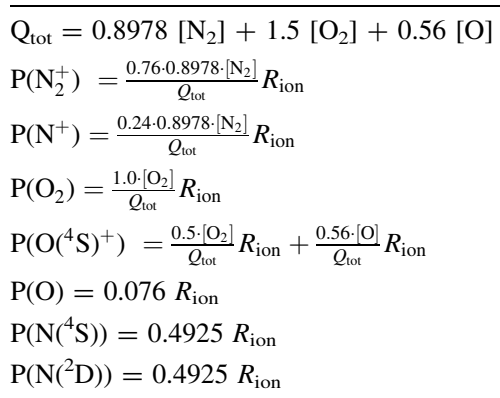

$R_{\text {ion }}$ ion pair production rates, $Q_{\text {tot }}$ total charge. Rates are based on Porter et al. (1976) and Rusch et al. (1981), adapted for the lower thermosphere by including ionisation of $\mathrm{O}$

Abbreviations for references as given in the following

BS 86: Brasseur and Solomon (1986), BC 83: Brasseur and Chatel 1983, Kazil 02: Kazil (2002), Tu 96: Turunen et al. (1996), Bö 83: Böhringer et al. (1983), Rees 89: Rees (1989), Matsu: Matsuoka et al. (1981), Vigg 92: Viggiano et al. (1992), udfa: http://www.udfa.net

Rusch et al. (1981); the ground state and excited states of $\mathrm{N}$ are partitioned according to Porter et al. (1976), see also Tables 3, 4, 5, 6, 7, 8, 9, 10, 11. ${ }^{2}$ More details can be found in Winkler (2007), Winkler et al. (2008), and Sinnhuber et al. (2012). A full list of the reactions, reaction rates, and references for the reaction rates used for the positive ion chemistry of UBIC as used here is given in Tables 3-11.

UBIC may act as an ion-chemistry module, attached to a neutral chemistry host model. In this mode, UBIC is initialised with the neutral atmosphere as computed by the host model as well as with prescribed ionisation rates at defined times (e.g., every hour). The ion-chemistry model is then used to calculate net effective production or loss rates of neutral species (e.g., $\left.\mathrm{N}\left({ }^{4} \mathrm{~S}\right), \mathrm{N}\left({ }^{2} \mathrm{D}\right), \mathrm{NO}, \mathrm{H}, \mathrm{OH}, \ldots\right)$ in the following way. Ion chemistry is computed until the charged atmosphere runs into equilibrium. From the main ion-neutral reactions, production and loss rates for different tracers are deduced by calculating the change of the neutral species using the equilibrium ion state and the initial neutral atmosphere over one UBIC model timestep, which typically is about 3-4 orders of magnitude smaller than the timestep of the neutral model.

At some altitudes, ion chemistry needs comparatively small timesteps $\left(\sim 10^{-3}\right.$ s $)$ and thus up to some millions of iterations to converge. Hence, coupling UBIC to a $3 D$ host model is extremely expensive in CPU usage. Recent studies were performed using a onedimensional host model in order to allow for several different studies of ion chemistry.

In the UBIC runs shown here, data from the AIMOS model based on observed proton and electron fluxes are used as external forcing of the ionisation rates (Wissing and Kallenrode 2010). UBIC model runs have been initialised with WACCM data at $70^{\circ} \mathrm{N} /$ $180^{\circ} \mathrm{E}$ for 25 October 2003 (e.g., Marsh et al. 2007; Smith 2012) and were carried out on WACCM levels in the altitude range from 40 to $140 \mathrm{~km}$ until 10 November 2003. WACCM NO in the lower thermosphere was fairly high already on 25 October, presumably because of high geomagnetic activity on the days before. As the lifetime of NO is several

\footnotetext{
${ }^{2}$ List of all reactions, reaction rates and references for the reaction rates of the primary ion production and positive ion and neutral-ion chemistry as implemented in the UBIC model.
} 
Table 4 Ion-neutral, recombination, and neutral-neutral reactions of nitrogen, oxygen, and carbon species. In the rate coefficients, $5.0(-11)$ denotes $5.0 \cdot 10^{-11} \mathrm{n}$ is 2 for pressure independent, 3 for pressure dependent reactions, $\mathrm{T}$ is the temperature in $\mathrm{K}$, and $\mathrm{M}$ is the total air density in $\mathrm{cm}^{-3}$

\begin{tabular}{|c|c|c|c|c|}
\hline Reactants & & Products & Rate coefficient $\left(\mathrm{cm}^{3(n-1)} \mathrm{s}^{-1}\right)$ & Refs. \\
\hline $\mathrm{N}_{2}^{+}+\mathrm{O}_{2}$ & $\rightarrow$ & $\mathrm{O}_{2}^{+}+\mathrm{N}_{2}$ & $5.0(-11)(T / 300)^{-0.8}$ & Rees 89 \\
\hline $\mathrm{N}_{2}^{+}+\mathrm{O}$ & $\rightarrow$ & $\mathrm{NO}^{+}+\mathrm{N}\left({ }^{2} \mathrm{D}\right)$ & $1.4(-10)(T / 300)^{-0.44}$ & Rees 89 \\
\hline $\mathrm{N}_{2}^{+}+\mathrm{O}$ & $\rightarrow$ & $\mathrm{NO}^{+}+\mathrm{N}\left({ }^{4} \mathrm{~S}\right)$ & $1.4(-10)(T / 300)^{-0.44} \cdot 0.0$ & Rees 89 \\
\hline $\mathrm{N}_{2}^{+}+e^{-}$ & $\rightarrow$ & $\mathrm{N}\left({ }^{2} \mathrm{D}\right)+\mathrm{N}\left({ }^{2} \mathrm{D}\right)$ & $1.8(-7)(T / 300)^{-0.39} \cdot 0.56$ & Rees 89 \\
\hline $\mathrm{N}_{2}^{+}+e^{-}$ & $\rightarrow$ & $\mathrm{N}\left({ }^{4} \mathrm{~S}\right)+\mathrm{N}\left({ }^{4} \mathrm{~S}\right)$ & $1.8(-7)(T / 300)^{-0.39} \cdot 0.44$ & Rees 89 \\
\hline $\mathrm{N}_{2}^{+}+\mathrm{O}$ & $\rightarrow$ & $\mathrm{O}^{+}\left({ }^{4} \mathrm{~S}\right)+\mathrm{N}_{2}$ & $1.4(-10)(T / 300)^{-0.44}$ & Rees 89 \\
\hline $\mathrm{O}^{+}\left({ }^{4} \mathrm{~S}\right)+\mathrm{O}_{2}$ & $\rightarrow$ & $\mathrm{O}_{2}^{+}+\mathrm{O}$ & $2.0(-11)(T / 300)^{-0.40}$ & Rees 89 \\
\hline $\mathrm{O}_{2}^{+}+e^{-}$ & $\rightarrow$ & $\mathrm{O}\left({ }^{1} \mathrm{D}\right)+\mathrm{O}$ & $1.9(-7)(T / 300)^{-0.50}$ & Rees 89 \\
\hline $\mathrm{O}^{+}\left({ }^{2} \mathrm{D}\right)+e^{-}$ & $\rightarrow$ & $\mathrm{O}^{+}\left({ }^{4} \mathrm{~S}\right)+e^{-}$ & $7.8(-8)(T / 300)^{-0.50}$ & Rees 89 \\
\hline $\mathrm{O}^{+}\left({ }^{2} \mathrm{P}\right)+e^{-}$ & $\rightarrow$ & $\mathrm{O}^{+}\left({ }^{4} \mathrm{~S}\right)+e^{-}$ & $4.0(-8)(T / 300)^{-0.50}$ & Rees 89 \\
\hline $\mathrm{H}^{+}+\mathrm{O}$ & $\rightarrow$ & $\mathrm{O}^{+}\left({ }^{4} \mathrm{~S}\right)+\mathrm{H}$ & $5.34(-10)$ & Rees 89 \\
\hline $\mathrm{O}^{+}\left({ }^{4} \mathrm{~S}\right)+\mathrm{N}_{2}$ & $\rightarrow$ & $\mathrm{NO}^{+}+\mathrm{N}\left({ }^{4} \mathrm{~S}\right)$ & $1.2(-12)(T / 300)^{-0.74}$ & Rees 89 \\
\hline $\mathrm{O}^{+}\left({ }^{2} \mathrm{P}\right)+e^{-}$ & $\rightarrow$ & $\mathrm{O}^{+}\left({ }^{2} \mathrm{D}\right)+e^{-}$ & $1.5(-7)(T / 300)^{-0.50}$ & Rees 89 \\
\hline $\mathrm{NO}^{+}+e^{-}$ & $\rightarrow$ & $\mathrm{O}+\mathrm{N}\left({ }^{4} \mathrm{~S}\right)$ & $4.2(-7)(T / 300)^{-0.85} \cdot 0.22$ & Rees 89 \\
\hline $\mathrm{NO}^{+}+e^{-}$ & $\rightarrow$ & $\mathrm{O}+\mathrm{N}\left({ }^{2} \mathrm{D}\right)$ & $4.2(-7)(T / 300)^{-0.85} \cdot 0.78$ & Rees 89 \\
\hline $\mathrm{N}\left({ }^{2} \mathrm{D}\right)+e^{-}$ & $\rightarrow$ & $\mathrm{N}\left({ }^{4} \mathrm{~S}\right)+e^{-}$ & $5.5(-10)(T / 300)^{-0.50}$ & Rees 89 \\
\hline $\mathrm{N}\left({ }^{2} \mathrm{D}\right)+\mathrm{O}$ & $\rightarrow$ & $\mathrm{N}\left({ }^{4} \mathrm{~S}\right)+\mathrm{O}$ & $2.0(-12)$ & Rees 89 \\
\hline $\mathrm{N}\left({ }^{2} \mathrm{D}\right)$ & $\rightarrow$ & $\mathrm{N}\left({ }^{4} \mathrm{~S}\right)$ & $1.06(-5)$ & Rees 89 \\
\hline $\mathrm{O}_{2}^{+}+\mathrm{H}_{2} \mathrm{O}$ & $\rightarrow$ & $\mathrm{O}_{2}^{+}\left(\mathrm{H}_{2} \mathrm{O}\right)$ & $2.5(-28)\left[\mathrm{N}_{2}\right]$ & Kazil 02 \\
\hline $\mathrm{O}_{2}^{+}+\mathrm{H}_{2} \mathrm{O}$ & $\rightarrow$ & $\mathrm{O}_{2}^{+}\left(\mathrm{H}_{2} \mathrm{O}\right)$ & $2.6(-28)\left[\mathrm{O}_{2}\right]$ & Kazil 02 \\
\hline $\mathrm{O}_{2}^{+}+\mathrm{O}_{2}$ & $\rightarrow$ & $\mathrm{O}_{4}^{+}$ & $2.6(-30)(T / 300)^{-0.32} \cdot M$ & BS 86 \\
\hline $\mathrm{NO}_{2}^{+}\left(\mathrm{H}_{2} \mathrm{O}\right)+\mathrm{H}_{2} \mathrm{O}$ & $\rightarrow$ & $\mathrm{NO}_{2}^{+}\left(\mathrm{H}_{2} \mathrm{O}\right)_{2}$ & $2.0(-27) \cdot M$ & BS 86 \\
\hline $\mathrm{O}_{4}^{+}$ & $\rightarrow$ & $\mathrm{O}_{2}^{+}+\mathrm{O}_{2}$ & $2.4(-6)(T / 300)^{-1.0} \cdot \mathrm{e}^{\frac{-4,900}{T}} \cdot M$ & \\
\hline $\mathrm{O}_{2}^{+}\left(\mathrm{H}_{2} \mathrm{O}\right)+\mathrm{O}_{2}$ & $\rightarrow$ & $\mathrm{O}_{4}^{+}+\mathrm{H}_{2} \mathrm{O}$ & $2.0(-10) \cdot \mathrm{e}^{\frac{-2.300}{T}}$ & $\mathrm{BC} 83$ \\
\hline $\mathrm{O}^{+}\left({ }^{2} \mathrm{D}\right)+\mathrm{O}$ & $\rightarrow$ & $\mathrm{O}^{+}\left({ }^{4} \mathrm{~S}\right)+\mathrm{O}$ & $1.0(-11)$ & Rees 89 \\
\hline $\mathrm{O}^{+}\left({ }^{2} \mathrm{D}\right)+\mathrm{N}_{2}$ & $\rightarrow$ & $\mathrm{O}^{+}\left({ }^{4} \mathrm{~S}\right)+\mathrm{N}_{2}$ & $8.0(-10)$ & Rees 89 \\
\hline $\mathrm{O}^{+}\left({ }^{2} \mathrm{P}\right)+\mathrm{O}$ & $\rightarrow$ & $\mathrm{O}^{+}\left({ }^{4} \mathrm{~S}\right)+\mathrm{O}$ & $5.2(-11)$ & Rees 89 \\
\hline $\mathrm{O}^{+}\left({ }^{2} \mathrm{P}\right)$ & $\rightarrow$ & $\mathrm{O}^{+}\left({ }^{4} \mathrm{~S}\right)$ & $4.7 \cdot 10^{-2}$ & Rees 89 \\
\hline $\mathrm{N}^{+}+\mathrm{O}_{2}$ & $\rightarrow$ & $\mathrm{O}^{+}\left({ }^{4} \mathrm{~S}\right)+\mathrm{NO}$ & $3.0(-11)$ & Rees 89 \\
\hline $\mathrm{O}^{+}\left({ }^{4} \mathrm{~S}\right)+\mathrm{NO}$ & $\rightarrow$ & $\mathrm{NO}^{+}+\mathrm{O}$ & $8.0(-13)$ & Rees 89 \\
\hline $\mathrm{O}^{+}\left({ }^{4} \mathrm{~S}\right)+\mathrm{H}$ & $\rightarrow$ & $\mathrm{H}^{+}+\mathrm{O}$ & $6.0(-10)$ & Rees 89 \\
\hline $\mathrm{O}^{+}\left({ }^{4} \mathrm{~S}\right)+\mathrm{N}\left({ }^{2} \mathrm{D}\right)$ & $\rightarrow$ & $\mathrm{N}^{+}+\mathrm{O}$ & $1.3(-10)$ & Rees 89 \\
\hline $\mathrm{O}^{+}\left({ }^{2} \mathrm{P}\right)$ & $\rightarrow$ & $\mathrm{O}^{+}\left({ }^{2} \mathrm{D}\right)$ & 0.171 & Rees 89 \\
\hline $\mathrm{O}^{+}\left({ }^{2} \mathrm{D}\right)$ & $\rightarrow$ & $\mathrm{O}^{+}\left({ }^{4} \mathrm{~S}\right)$ & $7.7(-5)$ & Rees 89 \\
\hline $\mathrm{O}^{+}\left({ }^{2} \mathrm{P}\right)+\mathrm{N}_{2}$ & $\rightarrow$ & $\mathrm{N}^{+}+\mathrm{NO}$ & $1.0(-10)$ & Rees 89 \\
\hline $\mathrm{O}_{2}^{+}\left(\mathrm{a}^{4} \Pi\right)+e^{-}$ & $\rightarrow$ & $\mathrm{O}+\mathrm{O}$ & $1.0(-7)$ & Rees 89 \\
\hline $\mathrm{O}_{2}^{+}\left(\mathrm{a}^{4} \Pi\right)$ & $\rightarrow$ & $\mathrm{O}_{2}^{+}$ & $1.0(-4)$ & Rees 89 \\
\hline $\mathrm{O}^{+}\left({ }^{2} \mathrm{P}\right)+\mathrm{N}\left({ }^{4} \mathrm{~S}\right)$ & $\rightarrow$ & $\mathrm{N}^{+}+\mathrm{O}$ & $1.0(-10)$ & Rees 89 \\
\hline $\mathrm{O}^{+}\left({ }^{2} \mathrm{D}\right)+\mathrm{N}\left({ }^{4} \mathrm{~S}\right)$ & $\rightarrow$ & $\mathrm{N}^{+}+\mathrm{O}$ & $7.5(-11)$ & Rees 89 \\
\hline $\mathrm{N}^{+}+\mathrm{O}_{2}$ & $\rightarrow$ & $\mathrm{NO}^{+}+\mathrm{O}$ & $2.6(-10)$ & Rees 89 \\
\hline $\mathrm{N}^{+}+\mathrm{O}$ & $\rightarrow$ & $\mathrm{O}^{+}\left({ }^{4} \mathrm{~S}\right)+\mathrm{N}\left({ }^{4} \mathrm{~S}\right)$ & $5.0(-13)$ & Rees 89 \\
\hline
\end{tabular}


Table 4 continued

\begin{tabular}{lllll}
\hline Reactants & & Products & Rate coefficient $\left(\mathrm{cm}^{3(n-1)} \mathrm{s}^{-1}\right)$ & Refs. \\
\hline $\mathrm{N}^{+}+\mathrm{H}$ & $\rightarrow$ & $\mathrm{H}^{+}+\mathrm{N}\left({ }^{4} \mathrm{~S}\right)$ & $3.6(-12)$ & Rees 89 \\
$\mathrm{~N}\left({ }^{2} \mathrm{D}\right)+\mathrm{O}_{2}$ & $\rightarrow$ & $\mathrm{NO}+\mathrm{O}$ & $5.3(-12) \cdot 0.98$ & Rees 89 \\
$\mathrm{~N}\left({ }^{2} \mathrm{D}\right)+\mathrm{O}_{2}$ & $\rightarrow$ & $\mathrm{NO}+\mathrm{O}\left({ }^{1} \mathrm{D}\right)$ & $5.3(-12) \cdot 0.02$ & Rees 89 \\
$\mathrm{~N}\left({ }^{2} \mathrm{D}\right)+\mathrm{NO}$ & $\rightarrow$ & $\mathrm{N}_{2}+\mathrm{O}$ & $7.0(-11)$ & Rees 89 \\
$\mathrm{CO}^{+}+\mathrm{CO}_{2}$ & $\rightarrow$ & $\mathrm{CO}_{2}^{+}+\mathrm{CO}$ & $1.1(-9)$ & Kazil 02 \\
$\mathrm{CO}^{+}+\mathrm{H}_{2} \mathrm{O}$ & $\rightarrow$ & $\mathrm{H}_{2} \mathrm{O}^{+}+\mathrm{CO}$ & $1.56(-9)$ & Kazil 02 \\
$\mathrm{CO}^{+}+\mathrm{H}_{2} \mathrm{O}$ & $\rightarrow$ & $\mathrm{HCO}^{+}+\mathrm{OH}$ & $8.4(-10)$ & Kazil 02 \\
\hline
\end{tabular}

Abbreviations for references see footnote in Table 3

Table 5 Protonised cluster ions; see also caption to Table 4

\begin{tabular}{|c|c|c|c|c|}
\hline Reactants & & Products & Rate coefficient $\left(\mathrm{cm}^{3(n-1)} \mathrm{s}^{-1}\right)$ & Refs. \\
\hline $\mathrm{H}^{+}\left(\mathrm{H}_{2} \mathrm{O}\right)+\mathrm{CO}_{2}$ & $\rightarrow$ & $\mathrm{H}^{+}\left(\mathrm{H}_{2} \mathrm{O}\right)\left(\mathrm{CO}_{2}\right)$ & $8.5(-28)(T / 300)^{-4.0} \cdot M$ & Kazil 02 \\
\hline $\mathrm{H}^{+}\left(\mathrm{H}_{2} \mathrm{O}\right)+\mathrm{H}_{2} \mathrm{O}$ & $\rightarrow$ & $\mathrm{H}^{+}\left(\mathrm{H}_{2} \mathrm{O}\right)_{2}$ & $4.6(-27)(T / 300)^{-4.0} \cdot M$ & Kazil 02 \\
\hline $\mathrm{H}^{+}\left(\mathrm{H}_{2} \mathrm{O}\right)+\mathrm{N}_{2}$ & $\rightarrow$ & $\mathrm{H}^{+}\left(\mathrm{H}_{2} \mathrm{O}\right)\left(\mathrm{N}_{2}\right)$ & $3.5(-31)(T / 300)^{-4.0} \cdot M$ & Kazil 02 \\
\hline $\mathrm{H}^{+}\left(\mathrm{H}_{2} \mathrm{O}\right)\left(\mathrm{CO}_{2}\right)+\mathrm{H}_{2} \mathrm{O}$ & $\rightarrow$ & $\mathrm{H}^{+}\left(\mathrm{H}_{2} \mathrm{O}\right)_{2}+\mathrm{CO}_{2}$ & $2.33(-9)(T / 300)^{-0.5} \cdot M+2.39(-10)$ & Kazil 02 \\
\hline $\mathrm{H}^{+}\left(\mathrm{H}_{2} \mathrm{O}\right)\left(\mathrm{CO}_{2}\right)$ & $\rightarrow$ & $\mathrm{H}^{+}\left(\mathrm{H}_{2} \mathrm{O}\right)+\mathrm{CO}_{2}$ & $5.50(-3)(T / 300)^{-5.0} \cdot \mathrm{e}^{\frac{-7,700}{T} M}$ & Kazil 02 \\
\hline $\mathrm{H}^{+}\left(\mathrm{H}_{2} \mathrm{O}\right)\left(\mathrm{N}_{2}\right)$ & $\rightarrow$ & $\mathrm{H}^{+}\left(\mathrm{H}_{2} \mathrm{O}\right)+\mathrm{N}_{2}$ & $1.0(-8)(T / 300)^{-5.4} \cdot \mathrm{e}^{\frac{-2,800}{T}} M$ & Kazil 02 \\
\hline $\mathrm{H}^{+}\left(\mathrm{H}_{2} \mathrm{O}\right)_{2}+\mathrm{CO}_{2}$ & $\rightarrow$ & $\mathrm{H}^{+}\left(\mathrm{H}_{2} \mathrm{O}\right)_{2}+\mathrm{CO}_{2}$ & $8.5(-28)(T / 300)^{-4.0} \cdot M$ & Kazil 02 \\
\hline $\mathrm{H}^{+}\left(\mathrm{H}_{2} \mathrm{O}\right)_{2}+\mathrm{H}_{2} \mathrm{O}$ & $\rightarrow$ & $\mathrm{H}^{+}\left(\mathrm{H}_{2} \mathrm{O}\right)_{3}$ & $8.6(-27)(T / 300)^{-7.5} \cdot M$ & Kazil 02 \\
\hline $\mathrm{H}^{+}\left(\mathrm{H}_{2} \mathrm{O}\right)_{2}+\mathrm{N}_{2}$ & $\rightarrow$ & $\mathrm{H}^{+}\left(\mathrm{H}_{2} \mathrm{O}\right)_{2}\left(\mathrm{~N}_{2}\right)$ & $3.5(-31)(T / 300)^{-4.0} \cdot M$ & Kazil 02 \\
\hline $\mathrm{H}^{+}\left(\mathrm{H}_{2} \mathrm{O}\right)_{2}$ & $\rightarrow$ & $\mathrm{H}^{+}\left(\mathrm{H}_{2} \mathrm{O}\right)+\mathrm{H}_{2} \mathrm{O}$ & $2.5(-2)(T / 300)^{-5.0} \cdot \mathrm{e}^{\frac{-15,900}{T} M}$ & Kazil 02 \\
\hline $\mathrm{H}^{+}\left(\mathrm{H}_{2} \mathrm{O}\right)_{2}\left(\mathrm{CO}_{2}\right)+\mathrm{H}_{2} \mathrm{O}$ & $\rightarrow$ & $\mathrm{H}^{+}\left(\mathrm{H}_{2} \mathrm{O}\right)_{3}+\mathrm{CO}_{2}$ & $2.27(-9)(T / 300)^{-0.5}+2.33(-10)$ & Kazil 02 \\
\hline $\mathrm{H}^{+}\left(\mathrm{H}_{2} \mathrm{O}\right)_{2}\left(\mathrm{CO}_{2}\right)$ & $\rightarrow$ & $\mathrm{H}^{+}\left(\mathrm{H}_{2} \mathrm{O}\right)_{2}+\mathrm{CO}_{2}$ & $1.0(-9)(T / 300)^{-5.0} \cdot \mathrm{e}^{\frac{-6,200}{T} M}$ & Kazil 02 \\
\hline $\mathrm{H}^{+}\left(\mathrm{H}_{2} \mathrm{O}\right)_{2}\left(\mathrm{~N}_{2}\right)$ & $\rightarrow$ & $\mathrm{H}^{+}\left(\mathrm{H}_{2} \mathrm{O}\right)_{2}+\mathrm{N}_{2}$ & $1.2(-8)(T / 300)^{-5.4} \cdot \mathrm{e}^{\frac{-2,700}{T} M}$ & Kazil 02 \\
\hline $\mathrm{H}^{+}\left(\mathrm{H}_{2} \mathrm{O}\right)_{3}+\mathrm{H}_{2} \mathrm{O}$ & $\rightarrow$ & $\mathrm{H}^{+}\left(\mathrm{H}_{2} \mathrm{O}\right)_{4}$ & $3.6(-27)(T / 300)^{-8.1} \cdot M$ & Kazil 02 \\
\hline $\mathrm{H}^{+}\left(\mathrm{H}_{2} \mathrm{O}\right)_{3}$ & $\rightarrow$ & $\mathrm{H}^{+}\left(\mathrm{H}_{2} \mathrm{O}\right)_{2}+\mathrm{H}_{2} \mathrm{O}$ & $1.2(-2)(T / 300)^{-8.5} \cdot \mathrm{e}^{\frac{-9,800}{T}} M$ & Kazil 02 \\
\hline $\mathrm{H}^{+}\left(\mathrm{H}_{2} \mathrm{O}\right)_{4}+\mathrm{H}_{2} \mathrm{O}$ & $\rightarrow$ & $\mathrm{H}^{+}\left(\mathrm{H}_{2} \mathrm{O}\right)_{5}$ & $4.6(-28)(T / 300)^{-14} \cdot M$ & Kazil 02 \\
\hline $\mathrm{H}^{+}\left(\mathrm{H}_{2} \mathrm{O}\right)_{4}$ & $\rightarrow$ & $\mathrm{H}^{+}\left(\mathrm{H}_{2} \mathrm{O}\right)_{3}+\mathrm{H}_{2} \mathrm{O}$ & $1.5(-1)(T / 300)^{-9.1} \cdot e^{\frac{-9,000}{T}} M$ & Kazil 02 \\
\hline $\mathrm{H}^{+}\left(\mathrm{H}_{2} \mathrm{O}\right)_{5}+\mathrm{H}_{2} \mathrm{O}$ & $\rightarrow$ & $\mathrm{H}^{+}\left(\mathrm{H}_{2} \mathrm{O}\right)_{6}$ & $5.8(-29)(T / 300)^{-15.3} \cdot M$ & Kazil 02 \\
\hline $\mathrm{H}^{+}\left(\mathrm{H}_{2} \mathrm{O}\right)_{5}$ & $\rightarrow$ & $\mathrm{H}^{+}\left(\mathrm{H}_{2} \mathrm{O}\right)_{4}+\mathrm{H}_{2} \mathrm{O}$ & $1.7(-3)(T / 300)^{-15} \cdot \mathrm{e}^{\frac{-6,400}{T}} M$ & Kazil 02 \\
\hline $\mathrm{H}^{+}\left(\mathrm{H}_{2} \mathrm{O}\right)_{6}+\mathrm{H}_{2} \mathrm{O}$ & $\rightarrow$ & $\mathrm{H}^{+}\left(\mathrm{H}_{2} \mathrm{O}\right)_{7}$ & $5.74(-29)(T / 300)^{-15.3} \cdot M$ & Kazil 02 \\
\hline $\mathrm{H}^{+}\left(\mathrm{H}_{2} \mathrm{O}\right)_{6}$ & $\rightarrow$ & $\mathrm{H}^{+}\left(\mathrm{H}_{2} \mathrm{O}\right)_{5}+\mathrm{H}_{2} \mathrm{O}$ & $4.0(-3)(T / 300)^{-16.3} \cdot \mathrm{e}^{\frac{-5,800}{T}} M$ & Kazil 02 \\
\hline $\mathrm{H}^{+}\left(\mathrm{H}_{2} \mathrm{O}\right)_{7}$ & $\rightarrow$ & $\mathrm{H}^{+}\left(\mathrm{H}_{2} \mathrm{O}\right)_{6}+\mathrm{H}_{2} \mathrm{O}$ & $7.17(-4)(T / 300)^{-16.3} \cdot \mathrm{e}^{\frac{-5,390}{T} M}$ & Kazil 02 \\
\hline
\end{tabular}

Abbreviations for references see footnote in Table Table 3

days in the lower thermosphere (see panel D of Fig. 5), these high values affect most of the model period. We only want to investigate the impact of energetic particle forcing during the reference model period, so NO in the initialisation was set to a constant mixing ratio of 1 ppm above $90 \mathrm{~km}$. 
Table 6 Acetonitril cluster ions; in the rate coefficients, $\mathrm{R}$ is the gas constant in $\mathrm{cal} \mathrm{K}^{-1} \mathrm{~mol}^{-1}$; see also caption to Table 4

\begin{tabular}{|c|c|c|c|c|}
\hline Reactants & & Products & Rate coefficient $\left(\mathrm{cm}^{3(n-1)} \mathrm{s}^{-1}\right)$ & Refs. \\
\hline $\mathrm{H}^{+}\left(\mathrm{H}_{2} \mathrm{O}\right)+\mathrm{CH}_{3} \mathrm{CN}$ & $\rightarrow$ & $\mathrm{H}^{+}\left(\mathrm{CH}_{3} \mathrm{CN}\right)\left(\mathrm{H}_{2} \mathrm{O}\right)$ & $2.15(-17)(T / 300)^{-4} \cdot M$ & BS 86 \\
\hline $\mathrm{H}^{+}\left(\mathrm{CH}_{3} \mathrm{CN}\right)\left(\mathrm{H}_{2} \mathrm{O}\right)$ & $\rightarrow$ & $\mathrm{H}^{+}\left(\mathrm{H}_{2} \mathrm{O}\right)+\mathrm{CH}_{3} \mathrm{CN}$ & $\begin{array}{c}2.15(-17)(T / 300)^{-4} \\
M \cdot \mathrm{e}^{\frac{29.3}{R}} \cdot \mathrm{e}^{\frac{-46,700}{T}}\end{array}$ & BS 86 \\
\hline $\mathrm{H}^{+}\left(\mathrm{H}_{2} \mathrm{O}\right)_{2}+\mathrm{CH}_{3} \mathrm{CN}$ & $\rightarrow$ & $\mathrm{H}^{+}\left(\mathrm{CH}_{3} \mathrm{CN}\right)\left(\mathrm{H}_{2} \mathrm{O}\right)_{2}$ & $1.77(-8) \cdot T^{-7.5} \cdot M$ & BS 86 \\
\hline $\mathrm{H}^{+}\left(\mathrm{CH}_{3} \mathrm{CN}\right)\left(\mathrm{H}_{2} \mathrm{O}\right)_{2}$ & $\rightarrow$ & $\mathrm{H}^{+}\left(\mathrm{H}_{2} \mathrm{O}\right)_{2}+\mathrm{CH}_{3} \mathrm{CN}$ & $\begin{array}{r}1.77(-8) \cdot T^{-7.5} \\
M \cdot \mathrm{e}^{\frac{30.1}{R}} \cdot \mathrm{e}^{\frac{-32,600}{T}}\end{array}$ & BS 86 \\
\hline $\mathrm{H}^{+}\left(\mathrm{H}_{2} \mathrm{O}\right)_{3}+\mathrm{CH}_{3} \mathrm{CN}$ & $\rightarrow$ & $\mathrm{H}^{+}\left(\mathrm{CH}_{3} \mathrm{CN}\right)\left(\mathrm{H}_{2} \mathrm{O}\right)_{3}$ & $2.2(-7) \cdot T^{-8.1} \cdot M$ & BS 86 \\
\hline $\mathrm{H}^{+}\left(\mathrm{CH}_{3} \mathrm{CN}\right)\left(\mathrm{H}_{2} \mathrm{O}\right)_{3}$ & $\rightarrow$ & $\mathrm{H}^{+}\left(\mathrm{H}_{2} \mathrm{O}\right)_{3}+\mathrm{CH}_{3} \mathrm{CN}$ & $\begin{array}{l}2.2(-7) \cdot T^{-8.1} \\
M \cdot \mathrm{e}^{\frac{33.2}{R}} \cdot \mathrm{e}^{\frac{-28.700}{T}}\end{array}$ & BS 86 \\
\hline $\mathrm{H}^{+}\left(\mathrm{H}_{2} \mathrm{O}\right)_{4}+\mathrm{CH}_{3} \mathrm{CN}$ & $\rightarrow$ & $\mathrm{H}^{+}\left(\mathrm{CH}_{3} \mathrm{CN}\right)\left(\mathrm{H}_{2} \mathrm{O}\right)_{4}$ & $1.13(7) \cdot T^{-14} \cdot M$ & BS 86 \\
\hline $\mathrm{H}^{+}\left(\mathrm{CH}_{3} \mathrm{CN}\right)\left(\mathrm{H}_{2} \mathrm{O}\right)_{4}$ & $\rightarrow$ & $\mathrm{H}^{+}\left(\mathrm{H}_{2} \mathrm{O}\right)_{4}+\mathrm{CH}_{3} \mathrm{CN}$ & $\begin{array}{l}1.13(7) \cdot T^{-14} \\
M \cdot \mathrm{e}^{\frac{26.6}{R}} \cdot \mathrm{e}^{\frac{-22,000}{T R}}\end{array}$ & BS 86 \\
\hline $\mathrm{H}^{+}\left(\mathrm{H}_{2} \mathrm{O}\right)_{5}+\mathrm{CH}_{3} \mathrm{CN}$ & $\rightarrow$ & $\mathrm{H}^{+}\left(\mathrm{CH}_{3} \mathrm{CN}\right)\left(\mathrm{H}_{2} \mathrm{O}\right)_{5}$ & $2.33(9) \cdot T^{-15.3} \cdot M$ & BS 86 \\
\hline $\mathrm{H}^{+}\left(\mathrm{CH}_{3} \mathrm{CN}\right)\left(\mathrm{H}_{2} \mathrm{O}\right)_{5}$ & $\rightarrow$ & $\mathrm{H}^{+}\left(\mathrm{H}_{2} \mathrm{O}\right)_{5}+\mathrm{CH}_{3} \mathrm{CN}$ & $\begin{array}{l}2.33(9) \cdot T^{-15.4} \\
M \cdot \mathrm{e}^{\frac{26.6}{R}} \cdot \mathrm{e}^{\frac{-19,700}{T R}}\end{array}$ & BS 86 \\
\hline $\mathrm{H}^{+}\left(\mathrm{H}_{2} \mathrm{O}\right)_{6}+\mathrm{CH}_{3} \mathrm{CN}$ & $\rightarrow$ & $\mathrm{H}^{+}\left(\mathrm{CH}_{3} \mathrm{CN}\right)\left(\mathrm{H}_{2} \mathrm{O}\right)_{6}$ & $2.3(9) \cdot T^{-15.3} \cdot M$ & BS 86 \\
\hline $\mathrm{H}^{+}\left(\mathrm{CH}_{3} \mathrm{CN}\right)\left(\mathrm{H}_{2} \mathrm{O}\right)_{6}$ & $\rightarrow$ & $\mathrm{H}^{+}\left(\mathrm{H}_{2} \mathrm{O}\right)_{6}+\mathrm{CH}_{3} \mathrm{CN}$ & $\begin{array}{l}2.3(9) \cdot T^{-15.4} \\
M \cdot e^{\frac{27.1}{R}} \cdot e^{\frac{-18,200}{T R}}\end{array}$ & BS 86 \\
\hline $\mathrm{H}^{+}\left(\mathrm{CH}_{3} \mathrm{CN}\right)+\left(\mathrm{H}_{2} \mathrm{O}\right)$ & $\rightarrow$ & $\mathrm{H}^{+}\left(\mathrm{CH}_{3} \mathrm{CN}\right)\left(\mathrm{H}_{2} \mathrm{O}\right)$ & $2.18(-17) \cdot T^{-4} \cdot M$ & BS 86 \\
\hline $\mathrm{H}^{+}\left(\mathrm{CH}_{3} \mathrm{CN}\right)\left(\mathrm{H}_{2} \mathrm{O}\right)$ & $\rightarrow$ & $\mathrm{H}^{+}\left(\mathrm{CH}_{3} \mathrm{CN}\right)+\left(\mathrm{H}_{2} \mathrm{O}\right)$ & $\begin{array}{r}2.18(-17) \cdot T^{-4} . \\
M \cdot \mathrm{e}^{\frac{28.4}{R}} \cdot \mathrm{e}^{\frac{-24.800}{T R}}\end{array}$ & BS 86 \\
\hline $\mathrm{H}^{+}\left(\mathrm{CH}_{3} \mathrm{CN}\right)\left(\mathrm{H}_{2} \mathrm{O}\right)+\mathrm{H}_{2} \mathrm{O}$ & $\rightarrow$ & $\mathrm{H}^{+}\left(\mathrm{CH}_{3} \mathrm{CN}\right)\left(\mathrm{H}_{2} \mathrm{O}\right)_{2}$ & $2.1(-8) \cdot T^{-7.5} \cdot M$ & BS 86 \\
\hline $\mathrm{H}^{+}\left(\mathrm{CH}_{3} \mathrm{CN}\right)\left(\mathrm{H}_{2} \mathrm{O}\right)_{2}$ & $\rightarrow$ & $\mathrm{H}^{+}\left(\mathrm{CH}_{3} \mathrm{CN}\right)\left(\mathrm{H}_{2} \mathrm{O}\right)+\mathrm{H}_{2} \mathrm{O}$ & $\begin{array}{r}2.18(-8) \cdot T^{-7.5} \\
M \cdot \mathrm{e}^{\frac{25.1}{R}} \cdot \mathrm{e}^{\frac{-17.500}{T R}}\end{array}$ & BS 86 \\
\hline $\mathrm{H}^{+}\left(\mathrm{CH}_{3} \mathrm{CN}\right)\left(\mathrm{H}_{2} \mathrm{O}\right)_{2}+\mathrm{H}_{2} \mathrm{O}$ & $\rightarrow$ & $\mathrm{H}^{+}\left(\mathrm{CH}_{3} \mathrm{CN}\right)\left(\mathrm{H}_{2} \mathrm{O}\right)_{3}$ & $2.79(-7) \cdot T^{-8.1} \cdot M$ & BS 86 \\
\hline $\mathrm{H}^{+}\left(\mathrm{CH}_{3} \mathrm{CN}\right)_{2}\left(\mathrm{H}_{2} \mathrm{O}\right)_{4}$ & $\rightarrow$ & $\mathrm{H}^{+}\left(\mathrm{CH}_{3} \mathrm{CN}\right)\left(\mathrm{H}_{2} \mathrm{O}\right)_{4}+\mathrm{CH}_{3} \mathrm{CN}$ & $\begin{array}{r}2.26(9) \cdot T^{-15.3} \\
M \cdot \mathrm{e}^{\frac{22}{R}} \cdot \mathrm{e}^{\frac{-14,400}{T R}}\end{array}$ & BS 86 \\
\hline $\mathrm{H}^{+}\left(\mathrm{CH}_{3} \mathrm{CN}\right)_{2}+\mathrm{H}_{2} \mathrm{O}$ & $\rightarrow$ & $\mathrm{H}^{+}\left(\mathrm{CH}_{3} \mathrm{CN}\right)_{2}\left(\mathrm{H}_{2} \mathrm{O}\right)$ & $2.04(-8) \cdot T^{-7.5} \cdot M$ & BS 86 \\
\hline $\mathrm{H}^{+}\left(\mathrm{CH}_{3} \mathrm{CN}\right)_{2}\left(\mathrm{H}_{2} \mathrm{O}\right)$ & $\rightarrow$ & $\mathrm{H}^{+}\left(\mathrm{CH}_{3} \mathrm{CN}\right)_{2}+\mathrm{H}_{2} \mathrm{O}$ & $\begin{array}{r}2.04(-8) \cdot T^{-7.5} \\
M \cdot \mathrm{e}^{\frac{24.6}{R}} \cdot \mathrm{e}^{\frac{-15,900}{T R}}\end{array}$ & BS 86 \\
\hline $\mathrm{H}^{+}\left(\mathrm{CH}_{3} \mathrm{CN}\right)_{2}\left(\mathrm{H}_{2} \mathrm{O}\right)+\mathrm{H}_{2} \mathrm{O}$ & $\rightarrow$ & $\mathrm{H}^{+}\left(\mathrm{CH}_{3} \mathrm{CN}\right)_{2}\left(\mathrm{H}_{2} \mathrm{O}\right)_{2}$ & $2.73(-7) \cdot T^{-8.1} \cdot M$ & BS 86 \\
\hline $\mathrm{H}^{+}\left(\mathrm{CH}_{3} \mathrm{CN}\right)_{2}\left(\mathrm{H}_{2} \mathrm{O}\right)_{2}$ & $\rightarrow$ & $\mathrm{H}^{+}\left(\mathrm{CH}_{3} \mathrm{CN}\right)_{2}\left(\mathrm{H}_{2} \mathrm{O}\right)+\mathrm{H}_{2} \mathrm{O}$ & $\begin{array}{r}2.73(-7) \cdot T^{-8.1} \\
M \cdot \mathrm{e}^{\frac{25.2}{R}} \cdot \mathrm{e}^{\frac{-15,300}{T R}}\end{array}$ & BS 86 \\
\hline $\mathrm{H}^{+}\left(\mathrm{CH}_{3} \mathrm{CN}\right)_{2}\left(\mathrm{H}_{2} \mathrm{O}\right)_{2}+\mathrm{H}_{2} \mathrm{O}$ & $\rightarrow$ & $\mathrm{H}^{+}\left(\mathrm{CH}_{3} \mathrm{CN}\right)_{2}\left(\mathrm{H}_{2} \mathrm{O}\right)_{3}$ & $1.14(7) \cdot T^{-14} \cdot M$ & BS 86 \\
\hline $\mathrm{H}^{+}\left(\mathrm{CH}_{3} \mathrm{CN}\right)_{2}\left(\mathrm{H}_{2} \mathrm{O}\right)_{3}$ & $\rightarrow$ & $\mathrm{H}^{+}\left(\mathrm{CH}_{3} \mathrm{CN}\right)_{2}\left(\mathrm{H}_{2} \mathrm{O}\right)_{2}+\mathrm{H}_{2} \mathrm{O}$ & $\begin{array}{l}1.14(7) \cdot T^{-14} \cdot \\
M \cdot \mathrm{e}^{\frac{22.3}{R}} \cdot \mathrm{e}^{\frac{-10,300}{T R}}\end{array}$ & BS 86 \\
\hline $\mathrm{H}^{+}\left(\mathrm{CH}_{3} \mathrm{CN}\right)_{2}\left(\mathrm{H}_{2} \mathrm{O}\right)_{3}+\mathrm{H}_{2} \mathrm{O}$ & $\rightarrow$ & $\mathrm{H}^{+}\left(\mathrm{CH}_{3} \mathrm{CN}\right)_{2}\left(\mathrm{H}_{2} \mathrm{O}\right)_{4}$ & $3.11(9) \cdot T^{-15.3} \cdot M$ & BS 86 \\
\hline $\mathrm{H}^{+}\left(\mathrm{CH}_{3} \mathrm{CN}\right)_{2}\left(\mathrm{H}_{2} \mathrm{O}\right)_{4}$ & $\rightarrow$ & $\mathrm{H}^{+}\left(\mathrm{CH}_{3} \mathrm{CN}\right)_{2}\left(\mathrm{H}_{2} \mathrm{O}\right)_{3}+\mathrm{H}_{2} \mathrm{O}$ & $\begin{array}{r}3.11(9) \cdot T^{-15.3} \\
M \cdot \mathrm{e}^{\frac{21.5}{R}} \cdot \mathrm{e}^{\frac{-9,700}{T R}}\end{array}$ & BS 86 \\
\hline $\mathrm{H}^{+}\left(\mathrm{CH}_{3} \mathrm{CN}\right)_{2}+\mathrm{CH}_{3} \mathrm{CN}$ & $\rightarrow$ & $\mathrm{H}^{+}\left(\mathrm{CH}_{3} \mathrm{CN}\right)_{3}$ & $1.51(-8) \cdot T^{-7.5} \cdot M$ & BS 86 \\
\hline $\mathrm{H}^{+}\left(\mathrm{CH}_{3} \mathrm{CN}\right)_{3}$ & $\rightarrow$ & $\mathrm{H}^{+}\left(\mathrm{CH}_{3} \mathrm{CN}\right)_{2}+\mathrm{CH}_{3} \mathrm{CN}$ & $\begin{array}{c}1.51(-8) \cdot T^{-7.5} \\
M \cdot \mathrm{e}^{\frac{10}{R}} \cdot \mathrm{e}^{\frac{-9,300}{T R}}\end{array}$ & BS 86 \\
\hline $\begin{array}{l}\mathrm{H}^{+}\left(\mathrm{CH}_{3} \mathrm{CN}\right)_{2}\left(\mathrm{H}_{2} \mathrm{O}\right)+ \\
\quad \mathrm{CH}_{3} \mathrm{CN}\end{array}$ & $\rightarrow$ & $\mathrm{H}^{+}\left(\mathrm{CH}_{3} \mathrm{CN}\right)_{3}\left(\mathrm{H}_{2} \mathrm{O}\right)$ & $1.98(-7) \cdot T^{-8.1} \cdot M$ & BS 86 \\
\hline
\end{tabular}


Table 6 continued

\begin{tabular}{|c|c|c|c|c|}
\hline Reactants & & Products & Rate coefficient $\left(\mathrm{cm}^{3(n-1)} \mathrm{s}^{-1}\right)$ & Refs. \\
\hline $\mathrm{H}^{+}\left(\mathrm{CH}_{3} \mathrm{CN}\right)_{3}\left(\mathrm{H}_{2} \mathrm{O}\right)$ & $\rightarrow$ & $\begin{array}{l}\mathrm{H}^{+}\left(\mathrm{CH}_{3} \mathrm{CN}\right)_{2}\left(\mathrm{H}_{2} \mathrm{O}\right)+ \\
\quad \mathrm{CH}_{3} \mathrm{CN}\end{array}$ & $\begin{array}{r}1.98(-7) \cdot T^{-8.1} \\
M \cdot \mathrm{e}^{\frac{27.3}{R}} \cdot \mathrm{e}^{\frac{-20,600}{T R}}\end{array}$ & BS 86 \\
\hline $\begin{array}{l}\mathrm{H}^{+}\left(\mathrm{CH}_{3} \mathrm{CN}\right)_{2}\left(\mathrm{H}_{2} \mathrm{O}\right)_{2}+ \\
\quad \mathrm{CH}_{3} \mathrm{CN}\end{array}$ & $\rightarrow$ & $\mathrm{H}^{+}\left(\mathrm{CH}_{3} \mathrm{CN}\right)_{3}\left(\mathrm{H}_{2} \mathrm{O}\right)_{2}$ & $1.05(7) \cdot T^{-14} \cdot M$ & BS 86 \\
\hline $\mathrm{H}^{+}\left(\mathrm{CH}_{3} \mathrm{CN}\right)_{3}\left(\mathrm{H}_{2} \mathrm{O}\right)_{2}$ & $\rightarrow$ & $\begin{array}{l}\mathrm{H}^{+}\left(\mathrm{CH}_{3} \mathrm{CN}\right)_{2}\left(\mathrm{H}_{2} \mathrm{O}\right)_{2}+ \\
\quad \mathrm{CH}_{3} \mathrm{CN}\end{array}$ & $\begin{array}{l}1.05(7) \cdot T^{-14} \cdot \\
M \cdot \mathrm{e}^{\frac{24.1}{R}} \cdot \mathrm{e}^{\frac{-15,000}{T R}}\end{array}$ & BS 86 \\
\hline $\mathrm{H}^{+}\left(\mathrm{CH}_{3} \mathrm{CN}\right)_{3}+\mathrm{H}_{2} \mathrm{O}$ & $\rightarrow$ & $\mathrm{H}^{+}\left(\mathrm{CH}_{3} \mathrm{CN}\right)_{3}\left(\mathrm{H}_{2} \mathrm{O}\right)$ & $2.69(-7) \cdot T^{-8.1} \cdot M$ & BS 86 \\
\hline $\mathrm{H}^{+}\left(\mathrm{CH}_{3} \mathrm{CN}\right)_{3}\left(\mathrm{H}_{2} \mathrm{O}\right)$ & $\rightarrow$ & $\mathrm{H}^{+}\left(\mathrm{CH}_{3} \mathrm{CN}\right)_{3}+\mathrm{H}_{2} \mathrm{O}$ & $\begin{array}{r}2.69(-7) \cdot T^{-8.1} \\
M \cdot \mathrm{e}^{\frac{32.9}{R}} \cdot \mathrm{e}^{\frac{-27,200}{T R}}\end{array}$ & BS 86 \\
\hline $\mathrm{H}^{+}\left(\mathrm{CH}_{3} \mathrm{CN}\right)_{3}\left(\mathrm{H}_{2} \mathrm{O}\right)+\mathrm{H}_{2} \mathrm{O}$ & $\rightarrow$ & $\mathrm{H}^{+}\left(\mathrm{CH}_{3} \mathrm{CN}\right)_{3}\left(\mathrm{H}_{2} \mathrm{O}\right)_{2}$ & $1.43(7) \cdot T^{-14} \cdot M$ & BS 86 \\
\hline $\mathrm{H}^{+}\left(\mathrm{CH}_{3} \mathrm{CN}\right)_{3}\left(\mathrm{H}_{2} \mathrm{O}\right)_{2}$ & $\rightarrow$ & $\mathrm{H}^{+}\left(\mathrm{CH}_{3} \mathrm{CN}\right)_{3}\left(\mathrm{H}_{2} \mathrm{O}\right)+\mathrm{H}_{2} \mathrm{O}$ & $\begin{array}{r}1.43(7) \cdot T^{-14} \\
M \cdot \mathrm{e}^{\frac{22}{R}} \cdot \mathrm{e}^{\frac{-9,700}{T R}}\end{array}$ & BS 86 \\
\hline
\end{tabular}

Abbreviations for references see footnote in Table 3

Table $7 \mathrm{NO}^{+}$and $\mathrm{NO}^{+}$cluster ions, see also caption to Table 4

\begin{tabular}{|c|c|c|c|c|}
\hline \multicolumn{2}{|l|}{ Reactants } & \multirow{2}{*}{$\frac{\text { Products }}{\mathrm{NO}^{+}\left(\mathrm{CO}_{2}\right)}$} & \multirow{2}{*}{$\begin{array}{l}\text { Rate coefficient }\left(\mathrm{cm}^{3(n-1)} \mathrm{s}^{-1}\right) \\
1.4(-29) \cdot(T / 300)^{-4.0} \cdot M\end{array}$} & \multirow{2}{*}{$\begin{array}{l}\text { Refs. } \\
\text { Kazil } 02\end{array}$} \\
\hline $\mathrm{NO}^{+}+\mathrm{CO}_{2}$ & $\rightarrow$ & & & \\
\hline $\mathrm{NO}^{+}+\mathrm{H}_{2} \mathrm{O}$ & $\rightarrow$ & $\mathrm{NO}^{+}\left(\mathrm{H}_{2} \mathrm{O}\right)$ & $1.6(-28) \cdot(T / 300)^{-4.7} \cdot M$ & Kazil 02 \\
\hline $\mathrm{NO}^{+}+\mathrm{N}_{2}$ & $\rightarrow$ & $\mathrm{NO}^{+}\left(\mathrm{N}_{2}\right)$ & $3.0(-31) \cdot(T / 300)^{-4.3} \cdot M$ & Kazil 02 \\
\hline $\mathrm{NO}^{+}\left(\mathrm{CO}_{2}\right)+\mathrm{H}_{2} \mathrm{O}$ & $\rightarrow$ & $\mathrm{NO}^{+}\left(\mathrm{H}_{2} \mathrm{O}\right)+\mathrm{CO}_{2}$ & $2.29(-9) \cdot(T / 300)^{-0.5} \cdot M+2.35(-10)$ & Kazil 02 \\
\hline $\mathrm{NO}^{+}\left(\mathrm{CO}_{2}\right)$ & $\rightarrow$ & $\mathrm{NO}^{+}+\mathrm{CO}_{2}$ & $6.2(-7) \cdot(T / 300)^{-5} \cdot \mathrm{e}^{\frac{-4.590}{T}} M$ & Kazil 02 \\
\hline $\mathrm{NO}^{+}\left(\mathrm{H}_{2} \mathrm{O}\right)+\mathrm{CO}_{2}$ & $\rightarrow$ & $\mathrm{NO}^{+}\left(\mathrm{H}_{2} \mathrm{O}\right)\left(\mathrm{CO}_{2}\right)$ & $7.0(-30) \cdot(T / 300)^{-4} \cdot M$ & Kazil 02 \\
\hline $\mathrm{NO}^{+}\left(\mathrm{H}_{2} \mathrm{O}\right)+\mathrm{H}_{2} \mathrm{O}$ & $\rightarrow$ & $\mathrm{NO}^{+}\left(\mathrm{H}_{2} \mathrm{O}\right)_{2}$ & $1.0(-27) \cdot(T / 300)^{-4.7} \cdot M$ & Kazil 02 \\
\hline $\mathrm{NO}^{+}\left(\mathrm{H}_{2} \mathrm{O}\right)+\mathrm{N}_{2}$ & $\rightarrow$ & $\mathrm{NO}^{+}\left(\mathrm{H}_{2} \mathrm{O}\right)\left(\mathrm{N}_{2}\right)$ & $2.0(-31) \cdot(T / 300)^{-4.4} \cdot M$ & Kazil 02 \\
\hline $\mathrm{NO}^{+}\left(\mathrm{H}_{2} \mathrm{O}\right)\left(\mathrm{CO}_{2}\right)+\mathrm{H}_{2} \mathrm{O}$ & $\rightarrow$ & $\mathrm{NO}^{+}\left(\mathrm{H}_{2} \mathrm{O}\right)_{2}+\mathrm{CO}_{2}$ & $2.25(-9) \cdot(T / 300)^{-0.5} \cdot M+2.3(-10)$ & Kazil 02 \\
\hline $\mathrm{NO}^{+}\left(\mathrm{H}_{2} \mathrm{O}\right)\left(\mathrm{CO}_{2}\right)$ & $\rightarrow$ & $\mathrm{NO}^{+}\left(\mathrm{H}_{2} \mathrm{O}\right)+\mathrm{CO}_{2}$ & $3.8(-6) \cdot(T / 300)^{-5} \cdot \mathrm{e}^{\frac{-4,025}{T}} M$ & Kazil 02 \\
\hline $\mathrm{NO}^{+}\left(\mathrm{H}_{2} \mathrm{O}\right)\left(\mathrm{N}_{2}\right)$ & $\rightarrow$ & $\mathrm{NO}^{+}\left(\mathrm{H}_{2} \mathrm{O}\right)+\mathrm{N}_{2}$ & $6.3(-8) \cdot(T / 300)^{-5.4} \cdot \mathrm{e}^{\frac{-2,150}{T} M}$ & Kazil 02 \\
\hline $\mathrm{NO}^{+}\left(\mathrm{H}_{2} \mathrm{O}\right)_{2}+\mathrm{CO}_{2}$ & $\rightarrow$ & $\mathrm{NO}^{+}\left(\mathrm{H}_{2} \mathrm{O}\right)_{2}\left(\mathrm{CO}_{2}\right)$ & $7.0(-30) \cdot(T / 300)^{-3} \cdot M$ & Kazil 02 \\
\hline $\mathrm{NO}^{+}\left(\mathrm{H}_{2} \mathrm{O}\right)_{2}+\mathrm{H}_{2} \mathrm{O}$ & $\rightarrow$ & $\mathrm{NO}^{+}\left(\mathrm{H}_{2} \mathrm{O}\right)_{3}$ & $9.0(-28) \cdot(T / 300)^{-4.7} \cdot M$ & Kazil 02 \\
\hline $\mathrm{NO}^{+}\left(\mathrm{H}_{2} \mathrm{O}\right)_{2}+\mathrm{N}_{2}$ & $\rightarrow$ & $\mathrm{NO}^{+}\left(\mathrm{H}_{2} \mathrm{O}\right)_{2}\left(\mathrm{~N}_{2}\right)$ & $2.0(-31) \cdot(T / 300)^{-4.4} \cdot M$ & Kazil 02 \\
\hline $\mathrm{NO}^{+}\left(\mathrm{H}_{2} \mathrm{O}\right)_{2}\left(\mathrm{CO}_{2}\right)+\mathrm{H}_{2} \mathrm{O}$ & $\rightarrow$ & $\mathrm{NO}^{+}\left(\mathrm{H}_{2} \mathrm{O}\right)_{3}+\mathrm{CO}_{2}$ & $2.22(-9) \cdot(T / 300)^{-0.5} \cdot M+2.27(-10)$ & Kazil 02 \\
\hline $\mathrm{NO}^{+}\left(\mathrm{H}_{2} \mathrm{O}\right)_{2}\left(\mathrm{CO}_{2}\right)$ & $\rightarrow$ & $\mathrm{NO}^{+}\left(\mathrm{H}_{2} \mathrm{O}\right)_{2}+\mathrm{CO}_{2}$ & $3.8(-6) \cdot(T / 300)^{-5} \cdot \mathrm{e}^{\frac{-3,335}{T}} M$ & Kazil 02 \\
\hline $\mathrm{NO}^{+}\left(\mathrm{H}_{2} \mathrm{O}\right)_{2}\left(\mathrm{~N}_{2}\right)$ & $\rightarrow$ & $\mathrm{NO}^{+}\left(\mathrm{H}_{2} \mathrm{O}\right)_{2}+\mathrm{N}_{2}$ & $6.3(-8) \cdot(T / 300)^{-5.4} \cdot \mathrm{e}^{\frac{-1,800}{T} M}$ & Kazil 02 \\
\hline $\mathrm{NO}^{+}\left(\mathrm{N}_{2}\right)+\mathrm{H}_{2} \mathrm{O}$ & $\rightarrow$ & $\mathrm{NO}^{+}\left(\mathrm{H}_{2} \mathrm{O}\right)+\mathrm{N}_{2}$ & $2.35(-9) \cdot(T / 300)^{-0.5} \cdot M+2.41(-10)$ & Kazil 02 \\
\hline $\mathrm{NO}^{+}\left(\mathrm{N}_{2}\right)$ & $\rightarrow$ & $\mathrm{NO}^{+}+\mathrm{N}_{2}$ & $1.5(-8) \cdot(T / 300)^{-5.3} \cdot \mathrm{e}^{\frac{-2,093}{T}} M$ & Kazil 02 \\
\hline
\end{tabular}

Abbreviations for references see footnote in Table 3 
Table 8 Recombination reactions with negative ions, see also caption to Table 4

\begin{tabular}{|c|c|c|c|c|}
\hline Reactants & & Products & Rate coefficient $\left(\mathrm{cm}^{3(n-1)} \mathrm{s}^{-1}\right)$ & Refs. \\
\hline $\mathrm{N}_{2}^{+}+\mathrm{X}^{-}$ & $\rightarrow$ & $\mathrm{N}_{2}$ & $\begin{array}{l}6.0(-8) \cdot(300 / T)^{-0.5} \\
\quad+1.25(-25)(300 / T)^{-4} \cdot M\end{array}$ & BS 86 \\
\hline $\mathrm{N}^{+}+\mathrm{X}^{-}$ & $\rightarrow$ & $N\left({ }^{4} S\right)$ & $\begin{array}{l}6.0(-8) \cdot(300 / T)^{-0.5} \\
\quad+1.25(-25)(300 / T)^{-4} \cdot M\end{array}$ & BS 86 \\
\hline $\mathrm{O}_{2}^{+}+\mathrm{X}^{-}$ & $\rightarrow$ & $\mathrm{O}_{2}$ & $\begin{array}{l}6.0(-8) \cdot(300 / T)^{-0.5} \\
\quad+1.25(-25)(300 / T)^{-4} \cdot M\end{array}$ & BS 86 \\
\hline $\mathrm{O}_{2}^{+}\left(\mathrm{a}^{4} \Pi\right)+\mathrm{X}^{-}$ & $\rightarrow$ & $\mathrm{O}_{2}$ & $\begin{array}{l}6.0(-8) \cdot(300 / T)^{-0.5} \\
\quad+1.25(-25)(300 / T)^{-4} \cdot M\end{array}$ & BS 86 \\
\hline $\mathrm{O}^{+}\left({ }^{4} \mathrm{~S}\right)+e^{-}$ & $\rightarrow$ & $\mathrm{O}$ & $4.0(-12) \cdot(T / 300)^{0.7}$ & Tu 96 \\
\hline $\mathrm{O}^{+}\left({ }^{4} \mathrm{~S}\right)+\mathrm{X}^{-}$ & $\rightarrow$ & $\mathrm{O}$ & $\begin{array}{l}6.0(-8) \cdot(300 / T)^{-0.5} \\
\quad+1.25(-25)(300 / T)^{-4} \cdot M\end{array}$ & BS 86 \\
\hline $\mathrm{O}^{+}\left({ }^{2} \mathrm{D}\right)+\mathrm{X}^{-}$ & $\rightarrow$ & $\mathrm{O}$ & $\begin{array}{l}6.0(-8) \cdot(300 / T)^{-0.5} \\
\quad+1.25(-25)(300 / T)^{-4} \cdot M\end{array}$ & BS 86 \\
\hline $\mathrm{O}^{+}\left({ }^{2} \mathrm{P}\right)+\mathrm{X}^{-}$ & $\rightarrow$ & $\mathrm{O}$ & $\begin{array}{l}6.0(-8) \cdot(300 / T)^{-0.5} \\
\quad+1.25(-25)(300 / T)^{-4} \cdot M\end{array}$ & BS 86 \\
\hline $\mathrm{NO}^{+}+\mathrm{X}^{-}$ & $\rightarrow$ & NO & $\begin{array}{l}6.0(-8) \cdot(300 / T)^{-0.5} \\
\quad+1.25(-25)(300 / T)^{-4} \cdot M\end{array}$ & BS 86 \\
\hline $\mathrm{H}^{+}+\mathrm{X}^{-}$ & $\rightarrow$ & $\mathrm{H}$ & $\begin{array}{l}6.0(-8) \cdot(300 / T)^{-0.5} \\
\quad+1.25(-25)(300 / T)^{-4} \cdot M\end{array}$ & BS 86 \\
\hline $\mathrm{O}_{4}^{+}+e^{-}$ & $\rightarrow$ & $2 \mathrm{O}_{2}$ & $4.2(-6) \cdot(300 / T)^{0.5}$ & Tu 96 \\
\hline $\mathrm{O}_{4}^{+}+\mathrm{X}^{-}$ & $\rightarrow$ & $2 \mathrm{O}_{2}$ & $\begin{array}{l}6.0(-8) \cdot(300 / T)^{-0.5} \\
\quad+1.25(-25)(300 / T)^{-4} \cdot M\end{array}$ & BS 86 \\
\hline $\mathrm{O}_{5}^{+}+\mathrm{X}^{-}$ & $\rightarrow$ & $2 \mathrm{O}_{2}+\mathrm{O}$ & $\begin{array}{l}6.0(-8) \cdot(300 / T)^{-0.5} \\
\quad+1.25(-25)(300 / T)^{-4} \cdot M\end{array}$ & BS 86 \\
\hline $\mathrm{O}_{2}^{+}\left(\mathrm{H}_{2} \mathrm{O}\right)+\mathrm{X}^{-}$ & $\rightarrow$ & $\mathrm{O}_{2}+\mathrm{H}_{2} \mathrm{O}$ & $\begin{array}{l}6.0(-8) \cdot(300 / T)^{-0.5} \\
\quad+1.25(-25)(300 / T)^{-4} \cdot M\end{array}$ & BS 86 \\
\hline $\mathrm{H}^{+}\left(\mathrm{H}_{2} \mathrm{O}\right)+\mathrm{X}^{-}$ & $\rightarrow$ & $\mathrm{H}+\mathrm{H}_{2} \mathrm{O}$ & $\begin{array}{l}6.0(-8) \cdot(300 / T)^{-0.5} \\
\quad+1.25(-25)(300 / T)^{-4} \cdot M\end{array}$ & BS 86 \\
\hline $\mathrm{H}^{+}\left(\mathrm{H}_{2} \mathrm{O}\right)_{2}+\mathrm{X}^{-}$ & $\rightarrow$ & $\mathrm{H}+2 \mathrm{H}_{2} \mathrm{O}$ & $\begin{array}{l}6.0(-8) \cdot(300 / T)^{-0.5} \\
\quad+1.25(-25)(300 / T)^{-4} \cdot M\end{array}$ & BS 86 \\
\hline $\mathrm{H}^{+}\left(\mathrm{H}_{2} \mathrm{O}\right)_{2}\left(\mathrm{~N}_{2}\right)+\mathrm{X}^{-}$ & $\rightarrow$ & $\mathrm{H}+2 \mathrm{H}_{2} \mathrm{O}+\mathrm{N}_{2}$ & $\begin{array}{l}6.0(-8) \cdot(300 / T)^{-0.5} \\
\quad+1.25(-25)(300 / T)^{-4} \cdot M\end{array}$ & BS 86 \\
\hline $\mathrm{H}^{+}\left(\mathrm{H}_{2} \mathrm{O}\right)\left(\mathrm{N}_{2}\right)+\mathrm{X}^{-}$ & $\rightarrow$ & $\mathrm{H}+\mathrm{H}_{2} \mathrm{O}+\mathrm{N}_{2}$ & $\begin{array}{l}6.0(-8) \cdot(300 / T)^{-0.5} \\
\quad+1.25(-25)(300 / T)^{-4} \cdot M\end{array}$ & BS 86 \\
\hline $\mathrm{H}^{+}\left(\mathrm{H}_{2} \mathrm{O}\right)\left(\mathrm{CO}_{2}\right)+\mathrm{X}^{-}$ & $\rightarrow$ & $\mathrm{H}+\mathrm{H}_{2} \mathrm{O}+\mathrm{CO}_{2}$ & $\begin{array}{l}6.0(-8) \cdot(300 / T)^{-0.5} \\
\quad+1.25(-25)(300 / T)^{-} \cdot M\end{array}$ & BS 86 \\
\hline $\mathrm{H}^{+}\left(\mathrm{H}_{2} \mathrm{O}\right)_{2}\left(\mathrm{CO}_{2}\right)+\mathrm{X}^{-}$ & $\rightarrow$ & $\mathrm{H}+2 \mathrm{H}_{2} \mathrm{O}+\mathrm{CO}_{2}$ & $\begin{array}{l}6.0(-8) \cdot(300 / T)^{-0.5} \\
\quad+1.25(-25)(300 / T)^{-4} \cdot M\end{array}$ & BS 86 \\
\hline $\mathrm{HCO}^{+}+e^{-}$ & $\rightarrow$ & $\mathrm{H}+\mathrm{CO}$ & $1.1(-7) \cdot(300 / T)$ & Kazil 02 \\
\hline $\mathrm{HCO}^{+}+\mathrm{X}^{-}$ & $\rightarrow$ & $\mathrm{H}+\mathrm{CO}$ & $\begin{array}{l}6.0(-8) \cdot(300 / T)^{-0.5} \\
\quad+1.25(-25)(300 / T)^{-4} \cdot M\end{array}$ & BS 86 \\
\hline $\mathrm{H}_{2} \mathrm{O}^{+}+\mathrm{X}^{-}$ & $\rightarrow$ & $\mathrm{O}+2 \mathrm{H}$ & $\begin{array}{l}6.0(-8) \cdot(300 / T)^{-0.5} \\
\quad+1.25(-25)(300 / T)^{-4} \cdot M\end{array}$ & BS 86 \\
\hline $\mathrm{H}_{2} \mathrm{O}^{+}+e^{-}$ & $\rightarrow$ & $\mathrm{O}+2 \mathrm{H}$ & $3.05(-7) \cdot(300 / T)^{-0.5}$ & udfa \\
\hline $\mathrm{H}_{2} \mathrm{O}^{+}+e^{-}$ & $\rightarrow$ & $\mathrm{O}+\mathrm{H}_{2}$ & $3.9(-8) \cdot(300 / T)^{-0.5}$ & udfa \\
\hline $\mathrm{H}_{2} \mathrm{O}^{+}+e^{-}$ & $\rightarrow$ & $\mathrm{OH}+\mathrm{H}$ & $8.6(-8) \cdot(300 / T)^{-0.5}$ & udfa \\
\hline $\mathrm{CO}^{+}+\mathrm{X}^{-}$ & $\rightarrow$ & $\mathrm{CO}$ & $\begin{array}{l}6.0(-8) \cdot(300 / T)^{-0.5} \\
\quad+1.25(-25)(300 / T)^{-4} \cdot M\end{array}$ & BS 86 \\
\hline
\end{tabular}


Table 8 continued

\begin{tabular}{|c|c|c|c|c|}
\hline Reactants & & Products & Rate coefficient $\left(\mathrm{cm}^{3(n-1)} \mathrm{s}^{-1}\right)$ & Refs. \\
\hline $\mathrm{CO}_{2}^{+}+\mathrm{X}^{-}$ & $\rightarrow$ & $\mathrm{CO}+\mathrm{O}$ & $\begin{array}{l}6.0(-8) \cdot(300 / T)^{-0.5} \\
\quad+1.25(-25)(300 / T)^{-4} \cdot M\end{array}$ & BS 86 \\
\hline $\mathrm{NO}_{2}^{+}+e^{-}$ & $\rightarrow$ & $\mathrm{NO}+\mathrm{O}$ & $3.0(-7) \cdot(300 / T)^{-0.5}$ & Kazil 02 \\
\hline $\mathrm{H}^{+}\left(\mathrm{H}_{2} \mathrm{O}\right)_{3}+\mathrm{X}^{-}$ & $\rightarrow$ & $\mathrm{H}+3 \mathrm{H}_{2} \mathrm{O}$ & $\begin{array}{l}6.0(-8) \cdot(300 / T)^{-0.5} \\
\quad+1.25(-25)(300 / T)^{-4} \cdot M\end{array}$ & BS 86 \\
\hline $\mathrm{H}^{+}\left(\mathrm{H}_{2} \mathrm{O}\right)_{4}+\mathrm{X}^{-}$ & $\rightarrow$ & $\mathrm{H}+4 \mathrm{H}_{2} \mathrm{O}$ & $\begin{array}{l}6.0(-8) \cdot(300 / T)^{-0.5} \\
\quad+1.25(-25)(300 / T)^{-4} \cdot M\end{array}$ & BS 86 \\
\hline $\mathrm{H}^{+}\left(\mathrm{H}_{2} \mathrm{O}\right)_{5}+\mathrm{X}^{-}$ & $\rightarrow$ & $\mathrm{H}+5 \mathrm{H}_{2} \mathrm{O}$ & $\begin{array}{l}6.0(-8) \cdot(300 / T)^{-0.5} \\
\quad+1.25(-25)(300 / T)^{-4} \cdot M\end{array}$ & BS 86 \\
\hline $\mathrm{H}^{+}\left(\mathrm{H}_{2} \mathrm{O}\right)_{6}+\mathrm{X}^{-}$ & $\rightarrow$ & $\mathrm{H}+6 \mathrm{H}_{2} \mathrm{O}$ & $\begin{array}{l}6.0(-8) \cdot(300 / T)^{-0.5} \\
\quad+1.25(-25)(300 / T)^{-4} \cdot M\end{array}$ & BS 86 \\
\hline $\mathrm{H}^{+}\left(\mathrm{H}_{2} \mathrm{O}\right)_{7}+\mathrm{X}^{-}$ & $\rightarrow$ & $\mathrm{H}+7 \mathrm{H}_{2} \mathrm{O}$ & $\begin{array}{l}6.0(-8) \cdot(300 / T)^{-0.5} \\
\quad+1.25(-25)(300 / T)^{-4} \cdot M\end{array}$ & BS 86 \\
\hline $\mathrm{NO}^{+}\left(\mathrm{H}_{2} \mathrm{O}\right)+\mathrm{X}^{-}$ & $\rightarrow$ & $\mathrm{NO}+\mathrm{H}_{2} \mathrm{O}$ & $\begin{array}{l}6.0(-8) \cdot(300 / T)^{-0.5} \\
\quad+1.25(-25)(300 / T)^{-4} \cdot M\end{array}$ & BS 86 \\
\hline $\mathrm{NO}^{+}\left(\mathrm{H}_{2} \mathrm{O}\right)_{2}+\mathrm{X}^{-}$ & $\rightarrow$ & $\mathrm{NO}+2 \mathrm{H}_{2} \mathrm{O}$ & $\begin{array}{l}6.0(-8) \cdot(300 / T)^{-0.5} \\
\quad+1.25(-25)(300 / T)^{-4} \cdot M\end{array}$ & BS 86 \\
\hline $\mathrm{NO}^{+}\left(\mathrm{H}_{2} \mathrm{O}\right)_{3}+\mathrm{X}^{-}$ & $\rightarrow$ & $\mathrm{NO}+3 \mathrm{H}_{2} \mathrm{O}$ & $\begin{array}{l}6.0(-8) \cdot(300 / T)^{-0.5} \\
\quad+1.25(-25)(300 / T)^{-4} \cdot M\end{array}$ & BS 86 \\
\hline $\mathrm{NO}^{+}\left(\mathrm{N}_{2}\right)+\mathrm{X}^{-}$ & $\rightarrow$ & $\mathrm{NO}+\mathrm{N}_{2}$ & $\begin{array}{l}6.0(-8) \cdot(300 / T)^{-0.5} \\
\quad+1.25(-25)(300 / T)^{-4} \cdot M\end{array}$ & BS 86 \\
\hline $\mathrm{NO}_{2}^{+}\left(\mathrm{H}_{2} \mathrm{O}\right)+\mathrm{X}^{-}$ & $\rightarrow$ & $\mathrm{NO}_{2}+\mathrm{H}_{2} \mathrm{O}$ & $\begin{array}{l}6.0(-8) \cdot(300 / T)^{-0.5} \\
\quad+1.25(-25)(300 / T)^{-4} \cdot M\end{array}$ & BS 86 \\
\hline $\mathrm{NO}_{2}^{+}\left(\mathrm{H}_{2} \mathrm{O}\right)_{2}+\mathrm{X}^{-}$ & $\rightarrow$ & $\mathrm{NO}_{2}+2 \mathrm{H}_{2} \mathrm{O}$ & $\begin{array}{l}6.0(-8) \cdot(300 / T)^{-0.5} \\
\quad+1.25(-25)(300 / T)^{-4} \cdot M\end{array}$ & BS 86 \\
\hline $\mathrm{NO}^{+}\left(\mathrm{H}_{2} \mathrm{O}\right)\left(\mathrm{N}_{2}\right)+\mathrm{X}^{-}$ & $\rightarrow$ & $\mathrm{NO}+\mathrm{H}_{2} \mathrm{O}+\mathrm{N}_{2}$ & $\begin{array}{l}6.0(-8) \cdot(300 / T)^{-0.5} \\
\quad+1.25(-25)(300 / T)^{-4} \cdot M\end{array}$ & BS 86 \\
\hline $\mathrm{NO}^{+}\left(\mathrm{H}_{2} \mathrm{O}\right)_{2}\left(\mathrm{~N}_{2}\right)+\mathrm{X}^{-}$ & $\rightarrow$ & $\mathrm{NO}+2 \mathrm{H}_{2} \mathrm{O}+\mathrm{N}_{2}$ & $\begin{array}{l}6.0(-8) \cdot(300 / T)^{-0.5} \\
\quad+1.25(-25)(300 / T)^{-4} \cdot M\end{array}$ & BS 86 \\
\hline $\mathrm{NO}^{+}\left(\mathrm{H}_{2} \mathrm{O}\right)_{2}\left(\mathrm{CO}_{2}\right)+\mathrm{X}^{-}$ & $\rightarrow$ & $\mathrm{NO}+2 \mathrm{H}_{2} \mathrm{O}+\mathrm{CO}_{2}$ & $\begin{array}{l}6.0(-8) \cdot(300 / T)^{-0.5} \\
\quad+1.25(-25)(300 / T)^{-4} \cdot M\end{array}$ & BS 86 \\
\hline $\mathrm{NO}^{+}\left(\mathrm{H}_{2} \mathrm{O}\right)\left(\mathrm{CO}_{2}\right)+\mathrm{X}^{-}$ & $\rightarrow$ & $\mathrm{NO}+\mathrm{H}_{2} \mathrm{O}+\mathrm{CO}_{2}$ & $\begin{array}{l}6.0(-8) \cdot(300 / T)^{-0.5} \\
\quad+1.25(-25)(300 / T)^{-4} \cdot M\end{array}$ & BS 86 \\
\hline $\mathrm{NO}^{+}\left(\mathrm{CO}_{2}\right)+\mathrm{X}^{-}$ & $\rightarrow$ & $\mathrm{NO}+\mathrm{CO}_{2}$ & $\begin{array}{l}6.0(-8) \cdot(300 / T)^{-0.5} \\
\quad+1.25(-25)(300 / T)^{-4} \cdot M\end{array}$ & BS 86 \\
\hline $\mathrm{H}^{+}\left(\mathrm{H}_{2} \mathrm{O}\right)(\mathrm{OH})+\mathrm{X}^{-}$ & $\rightarrow$ & $\mathrm{H}+\mathrm{H}_{2} \mathrm{O}+\mathrm{OH}$ & $\begin{array}{l}6.0(-8) \cdot(300 / T)^{-0.5} \\
\quad+1.25(-25)(300 / T)^{-4} \cdot M\end{array}$ & BS 86 \\
\hline $\mathrm{H}^{+}\left(\mathrm{CH}_{3} \mathrm{CN}\right)+\mathrm{X}^{-}$ & $\rightarrow$ & $\mathrm{H}+\mathrm{CH}_{3} \mathrm{CN}$ & $\begin{array}{l}6.0(-8) \cdot(300 / T)^{-0.5} \\
\quad+1.25(-25)(300 / T)^{-4} \cdot M\end{array}$ & BS 86 \\
\hline $\mathrm{H}^{+}\left(\mathrm{CH}_{3} \mathrm{CN}\right)\left(\mathrm{H}_{2} \mathrm{O}\right)+\mathrm{X}^{-}$ & $\rightarrow$ & $\mathrm{H}+\mathrm{CH}_{3} \mathrm{CN}+\mathrm{H}_{2} \mathrm{O}$ & $\begin{array}{l}6.0(-8) \cdot(300 / T)^{-0.5} \\
\quad+1.25(-25)(300 / T)^{-4} \cdot M\end{array}$ & BS 86 \\
\hline $\mathrm{H}^{+}\left(\mathrm{CH}_{3} \mathrm{CN}\right)\left(\mathrm{H}_{2} \mathrm{O}\right)_{2}+\mathrm{X}^{-}$ & $\rightarrow$ & $\mathrm{H}+\mathrm{CH}_{3} \mathrm{CN}+2 \mathrm{H}_{2} \mathrm{O}$ & $\begin{array}{l}6.0(-8) \cdot(300 / T)^{-0.5} \\
\quad+1.25(-25)(300 / T)^{-4} \cdot M\end{array}$ & BS 86 \\
\hline $\mathrm{H}^{+}\left(\mathrm{CH}_{3} \mathrm{CN}\right)\left(\mathrm{H}_{2} \mathrm{O}\right)_{3}+\mathrm{X}^{-}$ & $\rightarrow$ & $\mathrm{H}+\mathrm{CH}_{3} \mathrm{CN}+3 \mathrm{H}_{2} \mathrm{O}$ & $\begin{array}{l}6.0(-8) \cdot(300 / T)^{-0.5} \\
\quad+1.25(-25)(300 / T)^{-4} \cdot M\end{array}$ & BS 86 \\
\hline $\mathrm{H}^{+}\left(\mathrm{CH}_{3} \mathrm{CN}\right)\left(\mathrm{H}_{2} \mathrm{O}\right)_{4}+\mathrm{X}^{-}$ & $\rightarrow$ & $\mathrm{H}+\mathrm{CH}_{3} \mathrm{CN}+4 \mathrm{H}_{2} \mathrm{O}$ & $\begin{array}{l}6.0(-8) \cdot(300 / T)^{-0.5} \\
\quad+1.25(-25)(300 / T)^{-4} \cdot M\end{array}$ & BS 86 \\
\hline $\mathrm{H}^{+}\left(\mathrm{CH}_{3} \mathrm{CN}\right)\left(\mathrm{H}_{2} \mathrm{O}\right)_{5}+\mathrm{X}^{-}$ & $\rightarrow$ & $\mathrm{H}+\mathrm{CH}_{3} \mathrm{CN}+5 \mathrm{H}_{2} \mathrm{O}$ & $\begin{array}{l}6.0(-8) \cdot(300 / T)^{-0.5} \\
\quad+1.25(-25)(300 / T)^{-4} \cdot M\end{array}$ & BS 86 \\
\hline
\end{tabular}


Table 8 continued

\begin{tabular}{|c|c|c|c|c|}
\hline Reactants & & Products & Rate coefficient $\left(\mathrm{cm}^{3(n-1)} \mathrm{s}^{-1}\right)$ & Refs. \\
\hline $\mathrm{H}^{+}\left(\mathrm{CH}_{3} \mathrm{CN}\right)\left(\mathrm{H}_{2} \mathrm{O}\right)_{6}+\mathrm{X}^{-}$ & $\rightarrow$ & $\mathrm{H}+\mathrm{CH}_{3} \mathrm{CN}+6 \bullet \mathrm{H}_{2} \mathrm{O}$ & $\begin{array}{l}6.0(-8) \cdot(300 / T)^{-0.5} \\
\quad+1.25(-25)(300 / T)^{-4} \cdot M\end{array}$ & BS 86 \\
\hline $\mathrm{H}^{+}\left(\mathrm{CH}_{3} \mathrm{CN}\right)_{3}\left(\mathrm{H}_{2} \mathrm{O}\right)+\mathrm{X}^{-}$ & $\rightarrow$ & $\mathrm{H}+3 \mathrm{CH}_{3} \mathrm{CN}+\mathrm{H}_{2} \mathrm{O}$ & $\begin{array}{l}6.0(-8) \cdot(300 / T)^{-0.5} \\
\quad+1.25(-25)(300 / T)^{-4} \cdot M\end{array}$ & BS 86 \\
\hline $\mathrm{H}^{+}\left(\mathrm{CH}_{3} \mathrm{CN}\right)_{3}+\mathrm{X}^{-}$ & $\rightarrow$ & $\mathrm{H}+3 \mathrm{CH}_{3} \mathrm{CN}$ & $\begin{array}{l}6.0(-8) \cdot(300 / T)^{-0.5} \\
\quad+1.25(-25)(300 / T)^{-4} \cdot M\end{array}$ & BS 86 \\
\hline $\mathrm{H}^{+}\left(\mathrm{CH}_{3} \mathrm{CN}\right)_{2}\left(\mathrm{H}_{2} \mathrm{O}\right)_{4}+\mathrm{X}^{-}$ & $\rightarrow$ & $\mathrm{H}+2 \mathrm{CH}_{3} \mathrm{CN}+4 \mathrm{H}_{2} \mathrm{O}$ & $\begin{array}{l}6.0(-8) \cdot(300 / T)^{-0.5} \\
\quad+1.25(-25)(300 / T)^{-4} \cdot M\end{array}$ & BS 86 \\
\hline $\mathrm{H}^{+}\left(\mathrm{CH}_{3} \mathrm{CN}\right)_{2}\left(\mathrm{H}_{2} \mathrm{O}\right)_{3}+\mathrm{X}^{-}$ & $\rightarrow$ & $\mathrm{H}+2 \mathrm{CH}_{3} \mathrm{CN}+3 \mathrm{H}_{2} \mathrm{O}$ & $\begin{array}{l}6.0(-8) \cdot(300 / T)^{-0.5} \\
\quad+1.25(-25)(300 / T)^{-4} \cdot M\end{array}$ & BS 86 \\
\hline $\mathrm{H}^{+}\left(\mathrm{CH}_{3} \mathrm{CN}\right)_{2}\left(\mathrm{H}_{2} \mathrm{O}\right)_{2}+\mathrm{X}^{-}$ & $\rightarrow$ & $\mathrm{H}+2 \mathrm{CH}_{3} \mathrm{CN}+2 \mathrm{H}_{2} \mathrm{O}$ & $\begin{array}{l}6.0(-8) \cdot(300 / T)^{-0.5} \\
\quad+1.25(-25)(300 / T)^{-4} \cdot M\end{array}$ & BS 86 \\
\hline $\mathrm{H}^{+}\left(\mathrm{CH}_{3} \mathrm{CN}\right)_{2}\left(\mathrm{H}_{2} \mathrm{O}\right)+\mathrm{X}^{-}$ & $\rightarrow$ & $\mathrm{H}+2 \mathrm{CH}_{3} \mathrm{CN}+\mathrm{H}_{2} \mathrm{O}$ & $\begin{array}{l}6.0(-8) \cdot(300 / T)^{-0.5} \\
\quad+1.25(-25)(300 / T)^{-4} \cdot M\end{array}$ & BS 86 \\
\hline $\mathrm{H}^{+}\left(\mathrm{CH}_{3} \mathrm{CN}\right)_{2}+\mathrm{X}^{-}$ & $\rightarrow$ & $\mathrm{H}+2 \mathrm{CH}_{3} \mathrm{CN}$ & $\begin{array}{l}6.0(-8) \cdot(300 / T)^{-0.5} \\
\quad+1.25(-25)(300 / T)^{-4} \cdot M\end{array}$ & BS 86 \\
\hline
\end{tabular}

Abbreviations for references see footnote in Table 3

Table 9 Temperature independent ion-neutral reactions, see also caption to Table 4

\begin{tabular}{|c|c|c|c|c|}
\hline \multicolumn{2}{|l|}{ Reactants } & \multirow{2}{*}{$\begin{array}{l}\text { Products } \\
\mathrm{CO}_{2}^{+}+\mathrm{N}_{2}\end{array}$} & \multirow{2}{*}{$\begin{array}{l}\text { Rate coefficient } \\
\left(\mathrm{cm}^{3(n-1)} \mathrm{s}^{-1}\right)\end{array}$} & \multirow{2}{*}{$\begin{array}{l}\text { Refs. } \\
\text { Kazil } 02\end{array}$} \\
\hline $\mathrm{N}_{2}^{+}+\mathrm{CO}_{2}$ & $\rightarrow$ & & & \\
\hline $\mathrm{N}_{2}^{+}+\mathrm{CO}$ & $\rightarrow$ & $\mathrm{CO}^{+}+\mathrm{N}_{2}$ & $7.3(-11)$ & Kazil 02 \\
\hline $\mathrm{N}_{2}^{+}+\mathrm{H}_{2} \mathrm{O}$ & $\rightarrow$ & $\mathrm{H}_{2} \mathrm{O}^{+}+\mathrm{N}_{2}$ & $1.82(-9)$ & Kazil 02 \\
\hline $\mathrm{NO}^{+}\left(\mathrm{H}_{2} \mathrm{O}\right)\left(\mathrm{N}_{2}\right)+\mathrm{CO}_{2}$ & $\rightarrow$ & $\mathrm{NO}^{+}\left(\mathrm{H}_{2} \mathrm{O}\right)\left(\mathrm{CO}_{2}\right)+\mathrm{N}_{2}$ & $7.57(-10)$ & Kazil 02 \\
\hline $\mathrm{NO}^{+}\left(\mathrm{H}_{2} \mathrm{O}\right)_{2}\left(\mathrm{~N}_{2}\right)+\mathrm{CO}_{2}$ & $\rightarrow$ & $\mathrm{NO}^{+}\left(\mathrm{H}_{2} \mathrm{O}\right)_{2}\left(\mathrm{CO}_{2}\right)+\mathrm{N}_{2}$ & $7.3(-10)$ & Kazil 02 \\
\hline $\mathrm{NO}^{+}\left(\mathrm{H}_{2} \mathrm{O}\right)_{3}+\mathrm{H}_{2} \mathrm{O}$ & $\rightarrow$ & $\mathrm{H}^{+}\left(\mathrm{H}_{2} \mathrm{O}\right)_{3}+\mathrm{HNO}_{2}$ & $7.0(-11)$ & Kazil 02 \\
\hline $\mathrm{NO}^{+}\left(\mathrm{N}_{2}\right)+\mathrm{CO}_{2}$ & $\rightarrow$ & $\mathrm{NO}^{+}\left(\mathrm{CO}_{2}\right)+\mathrm{N}_{2}$ & $7.99(-10)$ & Kazil 02 \\
\hline $\mathrm{NO}_{2}^{+}+\mathrm{NO}$ & $\rightarrow$ & $\mathrm{NO}^{+}+\mathrm{NO}_{2}$ & $2.75(-10)$ & Kazil 02 \\
\hline $\mathrm{O}^{+}\left({ }^{4} \mathrm{~S}\right)+\mathrm{CO}_{2}$ & $\rightarrow$ & $\mathrm{O}_{2}^{+}+\mathrm{CO}$ & $1.06(-9)$ & Kazil $02^{\mathrm{a}}$ \\
\hline $\mathrm{O}^{+}\left({ }^{2} \mathrm{D}\right)+\mathrm{CO}_{2}$ & $\rightarrow$ & $\mathrm{O}_{2}^{+}+\mathrm{CO}$ & $1.06(-9) \cdot 0.05$ & $\operatorname{Vigg} 92^{\mathrm{a}}$ \\
\hline $\mathrm{O}^{+}\left({ }^{2} \mathrm{D}\right)+\mathrm{CO}_{2}$ & $\rightarrow$ & $\mathrm{CO}_{2}^{+}+\mathrm{O}$ & $1.06(-9) \cdot 0.95$ & $\operatorname{Vigg} 92^{\mathrm{a}}$ \\
\hline $\mathrm{O}^{+}\left({ }^{2} \mathrm{P}\right)+\mathrm{CO}_{2}$ & $\rightarrow$ & $\mathrm{O}_{2}^{+}+\mathrm{CO}$ & $1.06(-9) \cdot 0.05$ & Vigg $92^{\mathrm{a}}$ \\
\hline $\mathrm{O}^{+}\left({ }^{2} \mathrm{P}\right)+\mathrm{CO}_{2}$ & $\rightarrow$ & $\mathrm{CO}_{2}^{+}+\mathrm{O}$ & $1.06(-9) \cdot 0.95$ & $\operatorname{Vigg} 92^{\mathrm{a}}$ \\
\hline $\mathrm{O}^{+}\left({ }^{4} \mathrm{~S}\right)+\mathrm{H}_{2} \mathrm{O}$ & $\rightarrow$ & $\mathrm{H}_{2} \mathrm{O}^{+}+\mathrm{O}$ & $2.6(-9)$ & Kazil 02 \\
\hline $\mathrm{O}^{+}\left({ }^{2} \mathrm{D}\right)+\mathrm{H}_{2} \mathrm{O}$ & $\rightarrow$ & $\mathrm{H}_{2} \mathrm{O}^{+}+\mathrm{O}$ & $2.6(-9) \cdot 1.5$ & Kazil 02 \\
\hline $\mathrm{O}^{+}\left({ }^{2} \mathrm{P}\right)+\mathrm{H}_{2} \mathrm{O}$ & $\rightarrow$ & $\mathrm{H}_{2} \mathrm{O}^{+}+\mathrm{O}$ & $1.0(-9)$ & Kazil 02 \\
\hline $\mathrm{O}^{+}\left({ }^{4} \mathrm{~S}\right)+\mathrm{NO}_{2}$ & $\rightarrow$ & $\mathrm{NO}_{2}^{+}+\mathrm{O}$ & $(1.6(-9) / 6) \cdot 2$ & Kazil $02^{2}$ \\
\hline $\mathrm{O}^{+}\left({ }^{2} \mathrm{D}\right)+\mathrm{NO}_{2}$ & $\rightarrow$ & $\mathrm{NO}_{2}^{+}+\mathrm{O}$ & $(1.6(-9) / 6) \cdot 2$ & Kazil $02^{\mathrm{b}}$ \\
\hline $\mathrm{O}^{+}\left({ }^{2} \mathrm{P}\right)+\mathrm{NO}_{2}$ & $\rightarrow$ & $\mathrm{NO}_{2}^{+}+\mathrm{O}$ & $(1.6(-9) / 6) \cdot 2$ & $\begin{array}{l}\text { Kazil } \\
02^{2 b}\end{array}$ \\
\hline $\mathrm{O}_{2}^{+}+\mathrm{NO}_{2}$ & $\rightarrow$ & $\mathrm{NO}_{2}^{+}+\mathrm{O}_{2}$ & $6.6(-10)$ & Kazil 02 \\
\hline $\mathrm{O}_{4}^{+}+\mathrm{O}$ & $\rightarrow$ & $\mathrm{O}_{2}^{+}+\mathrm{O}_{3}$ & $3.0(-10)$ & BS 86 \\
\hline
\end{tabular}


Table 9 continued

\begin{tabular}{|c|c|c|c|c|}
\hline \multicolumn{2}{|l|}{ Reactants } & \multirow{2}{*}{$\begin{array}{l}\text { Products } \\
\mathrm{O}_{2}{ }^{+}\left(\mathrm{H}_{2} \mathrm{O}\right)+\mathrm{O}_{2}\end{array}$} & \multirow{2}{*}{$\frac{\begin{array}{l}\text { Rate coefficient } \\
\left(\mathrm{cm}^{3(n-1)} \mathrm{s}^{-1}\right)\end{array}}{1.5(-9)}$} & \multirow{2}{*}{$\begin{array}{l}\text { Refs. } \\
\text { BS } 86\end{array}$} \\
\hline $\mathrm{O}_{4}^{+}+\mathrm{H}_{2} \mathrm{O}$ & $\rightarrow$ & & & \\
\hline $\mathrm{O}_{4}^{+}+\mathrm{O}_{3}$ & $\rightarrow$ & $\mathrm{O}_{5}^{+}+\mathrm{O}_{2}$ & $1.0(-10)$ & BS 86 \\
\hline $\mathrm{O}_{5}^{+}+\mathrm{H}_{2} \mathrm{O}$ & $\rightarrow$ & $\mathrm{O}_{2}^{+}\left(\mathrm{H}_{2} \mathrm{O}\right)+\mathrm{O}_{3}$ & $1.2(-9)$ & BS 86 \\
\hline $\mathrm{O}_{2}^{+}\left(\mathrm{H}_{2} \mathrm{O}\right)+\mathrm{H}_{2} \mathrm{O}$ & $\rightarrow$ & $\mathrm{H}^{+}\left(\mathrm{H}_{2} \mathrm{O}\right)(\mathrm{OH})+\mathrm{O}_{2}$ & $1.0(-9)$ & BS 86 \\
\hline $\mathrm{O}_{2}^{+}\left(\mathrm{H}_{2} \mathrm{O}\right)+\mathrm{H}_{2} \mathrm{O}$ & $\rightarrow$ & $\mathrm{H}^{+}\left(\mathrm{H}_{2} \mathrm{O}\right)+\mathrm{OH}+\mathrm{O}_{2}$ & $2.0(-10)$ & BS 86 \\
\hline $\mathrm{H}^{+}\left(\mathrm{H}_{2} \mathrm{O}\right)+\mathrm{HNO}_{3}$ & $\rightarrow$ & $\mathrm{NO}_{2}^{+}\left(\mathrm{H}_{2} \mathrm{O}\right)+\mathrm{H}_{2} \mathrm{O}$ & $1.6(-9)$ & BS 86 \\
\hline $\mathrm{NO}_{2}^{+}\left(\mathrm{H}_{2} \mathrm{O}\right)_{2}+\mathrm{H}_{2} \mathrm{O}$ & $\rightarrow$ & $\mathrm{H}^{+}\left(\mathrm{H}_{2} \mathrm{O}\right)_{2}+\mathrm{HNO}_{3}$ & $2.0(-10)$ & BS 86 \\
\hline $\mathrm{H}^{+}\left(\mathrm{H}_{2} \mathrm{O}\right)+\mathrm{CH}_{3} \mathrm{CN}$ & $\rightarrow$ & $\mathrm{H}^{+}\left(\mathrm{CH}_{3} \mathrm{CN}\right)+\mathrm{H}_{2} \mathrm{O}$ & $4.5(-9)$ & BS 86 \\
\hline $\mathrm{H}^{+}\left(\mathrm{H}_{2} \mathrm{O}\right)_{2}+\mathrm{CH}_{3} \mathrm{CN}$ & $\rightarrow$ & $\mathrm{H}^{+}\left(\mathrm{CH}_{3} \mathrm{CN}\right)\left(\mathrm{H}_{2} \mathrm{O}\right)+\mathrm{H}_{2} \mathrm{O}$ & $4.0(-9)$ & BS 86 \\
\hline $\mathrm{H}^{+}\left(\mathrm{H}_{2} \mathrm{O}\right)_{3}+\mathrm{CH}_{3} \mathrm{CN}$ & $\rightarrow$ & $\mathrm{H}^{+}\left(\mathrm{CH}_{3} \mathrm{CN}\right)\left(\mathrm{H}_{2} \mathrm{O}\right)_{2}+\mathrm{H}_{2} \mathrm{O}$ & $3.6(-9)$ & BS 86 \\
\hline $\mathrm{H}^{+}\left(\mathrm{H}_{2} \mathrm{O}\right)_{4}+\mathrm{CH}_{3} \mathrm{CN}$ & $\rightarrow$ & $\mathrm{H}^{+}\left(\mathrm{CH}_{3} \mathrm{CN}\right)\left(\mathrm{H}_{2} \mathrm{O}\right)_{3}+\mathrm{H}_{2} \mathrm{O}$ & $3.3(-9)$ & BS 86 \\
\hline $\mathrm{H}^{+}\left(\mathrm{H}_{2} \mathrm{O}\right)_{5}+\mathrm{CH}_{3} \mathrm{CN}$ & $\rightarrow$ & $\mathrm{H}^{+}\left(\mathrm{CH}_{3} \mathrm{CN}\right)\left(\mathrm{H}_{2} \mathrm{O}\right)_{4}+\mathrm{H}_{2} \mathrm{O}$ & $3.0(-9)$ & BC 83 \\
\hline $\mathrm{H}^{+}\left(\mathrm{CH}_{3} \mathrm{CN}\right)\left(\mathrm{H}_{2} \mathrm{O}\right)_{2}+\mathrm{H}_{2} \mathrm{O}$ & $\rightarrow$ & $\mathrm{H}^{+}\left(\mathrm{H}_{2} \mathrm{O}\right)_{3}+\mathrm{CH}_{3} \mathrm{CN}$ & $3.5(-16)$ & BC 83 \\
\hline $\mathrm{H}^{+}\left(\mathrm{CH}_{3} \mathrm{CN}\right)\left(\mathrm{H}_{2} \mathrm{O}\right)_{3}+\mathrm{H}_{2} \mathrm{O}$ & $\rightarrow$ & $\mathrm{H}^{+}\left(\mathrm{H}_{2} \mathrm{O}\right)_{4}+\mathrm{CH}_{3} \mathrm{CN}$ & $5.0(-14)$ & BC 83 \\
\hline $\mathrm{H}^{+}\left(\mathrm{CH}_{3} \mathrm{CN}\right)\left(\mathrm{H}_{2} \mathrm{O}\right)_{4}+\mathrm{H}_{2} \mathrm{O}$ & $\rightarrow$ & $\mathrm{H}^{+}\left(\mathrm{H}_{2} \mathrm{O}\right)_{5}+\mathrm{CH}_{3} \mathrm{CN}$ & $4.3(-12)$ & BC 83 \\
\hline $\mathrm{H}^{+}\left(\mathrm{CH}_{3} \mathrm{CN}\right)\left(\mathrm{H}_{2} \mathrm{O}\right)_{2}+\mathrm{CH}_{3} \mathrm{CN}$ & $\rightarrow$ & $\mathrm{H}^{+}\left(\mathrm{CH}_{3} \mathrm{CN}\right)_{3}\left(\mathrm{H}_{2} \mathrm{O}\right)+\mathrm{H}_{2} \mathrm{O}$ & $3.3(-9)$ & BC 83 \\
\hline $\mathrm{H}^{+}\left(\mathrm{CH}_{3} \mathrm{CN}\right)_{3}\left(\mathrm{H}_{2} \mathrm{O}\right)+\mathrm{H}_{2} \mathrm{O}$ & $\rightarrow$ & $\mathrm{H}^{+}\left(\mathrm{CH}_{3} \mathrm{CH}\right)_{2}\left(\mathrm{H}_{2} \mathrm{O}\right)_{2}+\mathrm{CH}_{3} \mathrm{CN}$ & $9.0(-14)$ & BC 83 \\
\hline $\mathrm{H}^{+}\left(\mathrm{CH}_{3} \mathrm{CN}\right)\left(\mathrm{H}_{2} \mathrm{O}\right)_{4}+\mathrm{CH}_{3} \mathrm{CN}$ & $\rightarrow$ & $\mathrm{H}^{+}\left(\mathrm{CH}_{3} \mathrm{CN}\right)_{2}\left(\mathrm{H}_{2} \mathrm{O}\right)_{3}+\mathrm{H}_{2} \mathrm{O}$ & $3.0(-9)$ & BC 83 \\
\hline $\mathrm{H}^{+}\left(\mathrm{CH}_{3} \mathrm{CN}\right)_{2}\left(\mathrm{H}_{2} \mathrm{O}\right)_{3}+\mathrm{H}_{2} \mathrm{O}$ & $\rightarrow$ & $\mathrm{H}^{+}\left(\mathrm{CH}_{3} \mathrm{CN}\right)\left(\mathrm{H}_{2} \mathrm{O}\right)_{4}+\mathrm{CH}_{3} \mathrm{CN}$ & $4.3(-9)$ & BC 83 \\
\hline $\mathrm{O}_{2}^{+}+\mathrm{N}_{2} \mathrm{O}_{5}$ & $\rightarrow$ & $\mathrm{NO}_{2}^{+}+\mathrm{NO}_{3}+\mathrm{O}_{2}$ & $8.9(-10)$ & Bö 83 \\
\hline $\mathrm{H}^{+}\left(\mathrm{H}_{2} \mathrm{O}\right)+\mathrm{N}_{2} \mathrm{O}_{5}$ & $\rightarrow$ & $\mathrm{NO}_{2}^{+}\left(\mathrm{H}_{2} \mathrm{O}\right)+\mathrm{HNO}_{3}$ & $1.1(-9)$ & Вö 83 \\
\hline $\mathrm{H}^{+}\left(\mathrm{H}_{2} \mathrm{O}\right)_{2}+\mathrm{N}_{2} \mathrm{O}_{5}$ & $\rightarrow$ & $\mathrm{NO}_{2}^{+}\left(\mathrm{H}_{2} \mathrm{O}\right)_{2}+\mathrm{HNO}_{3}$ & $8.0(-10)$ & Вӧ 83 \\
\hline $\mathrm{H}^{+}\left(\mathrm{H}_{2} \mathrm{O}\right)_{3}+\mathrm{N}_{2} \mathrm{O}_{5}$ & $\rightarrow$ & $\mathrm{HNO}_{3}+$ products & $4.5(-11)$ & Bö $83^{\mathrm{c}}$ \\
\hline $\mathrm{H}^{+}\left(\mathrm{H}_{2} \mathrm{O}\right)_{4}+\mathrm{N}_{2} \mathrm{O}_{5}$ & $\rightarrow$ & $\mathrm{HNO}_{3}+$ products & $4.0(-12)$ & Bö $83^{\mathrm{c}}$ \\
\hline $\mathrm{H}^{+}\left(\mathrm{H}_{2} \mathrm{O}\right)_{5}+\mathrm{N}_{2} \mathrm{O}_{5}$ & $\rightarrow$ & $\mathrm{HNO}_{3}+$ products & $7.0(-12)$ & Bö $83^{\mathrm{c}}$ \\
\hline $\mathrm{H}^{+}\left(\mathrm{H}_{2} \mathrm{O}\right)_{6}+\mathrm{N}_{2} \mathrm{O}_{5}$ & $\rightarrow$ & $\mathrm{HNO}_{3}+$ products & $1.4(-11)$ & Вö $83^{\mathrm{c}}$ \\
\hline $\mathrm{H}^{+}\left(\mathrm{CH}_{3} \mathrm{CN}\right)+\mathrm{N}_{2} \mathrm{O}_{5}$ & $\rightarrow$ & $\mathrm{NO}_{2}^{+}+\mathrm{HNO}_{3}+\mathrm{CH}_{3} \mathrm{CN}$ & $8.3(-10)$ & Вö 83 \\
\hline $\mathrm{H}^{+}\left(\mathrm{CH}_{3} \mathrm{CN}\right)\left(\mathrm{H}_{2} \mathrm{O}\right)+\mathrm{N}_{2} \mathrm{O}_{5}$ & $\rightarrow$ & $\mathrm{NO}_{2}^{+}\left(\mathrm{H}_{2} \mathrm{O}\right)+\mathrm{HNO}_{3}+\mathrm{CH}_{3} \mathrm{CN}$ & $4.1(-10)$ & Bö 83 \\
\hline $\mathrm{H}^{+}\left(\mathrm{CH}_{3} \mathrm{CN}\right)\left(\mathrm{H}_{2} \mathrm{O}\right)_{2}+\mathrm{N}_{2} \mathrm{O}_{5}$ & $\rightarrow$ & $\mathrm{NO}_{2}^{+}\left(\mathrm{H}_{2} \mathrm{O}\right)+\mathrm{HNO}_{3}+\mathrm{H}_{2} \mathrm{O}$ & $7.0(-12)$ & Вö 83 \\
\hline $\mathrm{H}^{+}\left(\mathrm{CH}_{3} \mathrm{CN}\right)\left(\mathrm{H}_{2} \mathrm{O}\right)_{3}+\mathrm{N}_{2} \mathrm{O}_{5}$ & $\rightarrow$ & $\mathrm{NO}_{2}^{+}\left(\mathrm{H}_{2} \mathrm{O}\right)+\mathrm{HNO}_{3}+2 \mathrm{H}_{2} \mathrm{O}$ & $7.0(-12)$ & Вӧ 83 \\
\hline $\mathrm{H}^{+}\left(\mathrm{CH}_{3} \mathrm{CN}\right)\left(\mathrm{H}_{2} \mathrm{O}\right)_{4}+\mathrm{N}_{2} \mathrm{O}_{5}$ & $\rightarrow$ & $\mathrm{NO}_{2}^{+}\left(\mathrm{H}_{2} \mathrm{O}\right)+\mathrm{HNO}_{3}+\mathrm{H}_{2} \mathrm{O}$ & $1.0(-11)$ & Вö 83 \\
\hline
\end{tabular}

Abbreviations for references see footnote in Table 3

a The reaction of the ground state is taken from Kazil (2002), but the reaction rate is based on Anicich (1993) and Viggiano et al. (1992), which is in better agreement with other publications. The partitioning to the second channel for the excited states is based on Viggiano et al. (1992)

b Kazil (2002) only gives the bulk reaction rate. These were partitioned equally between ground- and excited states

c The product $\mathrm{NO}_{2}+\left(\mathrm{H}_{2} \mathrm{O}\right)_{n}, n \geq 3$, is assumed not to be stable, so is not included in the model; these reactions are added because they transfer $\mathrm{N}_{2} \mathrm{O}_{5}$ to $\mathrm{HNO}_{3}$ 
Table 10 Recombination reactions with electrons, see also caption to Table 4

\begin{tabular}{|c|c|c|c|c|}
\hline Reactants & & Products & $\begin{array}{l}\text { Rate coefficient } \\
\left(\mathrm{cm}^{3(n-1)} \mathrm{s}^{-1}\right)\end{array}$ & Refs. \\
\hline $\mathrm{N}^{+}+e^{-}$ & $\rightarrow$ & $\mathrm{N}\left({ }^{4} \mathrm{~S}\right)$ & $1.0(-12)$ & Tu 96 \\
\hline $\mathrm{O}^{+}\left({ }^{2} \mathrm{D}\right)+e^{-}$ & $\rightarrow$ & $\mathrm{O}$ & $4.0(-6)$ & BS 86 \\
\hline $\mathrm{O}^{+}\left({ }^{2} \mathrm{P}\right)+e^{-}$ & $\rightarrow$ & $\mathrm{O}$ & $4.0(-6)$ & BS 86 \\
\hline $\mathrm{H}^{+}+e^{-}$ & $\rightarrow$ & $\mathrm{H}$ & $1.0(-12)$ & BS 86 \\
\hline $\mathrm{O}_{5}^{+}+e^{-}$ & $\rightarrow$ & $2 \mathrm{O}_{2}+\mathrm{O}$ & $4.0(-6)$ & BS 86 \\
\hline $\mathrm{O}_{2}^{+}\left(\mathrm{H}_{2} \mathrm{O}\right)+e^{-}$ & $\rightarrow$ & $\mathrm{O}_{2}+\mathrm{H}_{2} \mathrm{O}$ & $2.0(-6)$ & Tu 96 \\
\hline $\mathrm{H}^{+}\left(\mathrm{H}_{2} \mathrm{O}\right)+e^{-}$ & $\rightarrow$ & $\mathrm{H}+\mathrm{H}_{2} \mathrm{O}$ & $4.0(-6)$ & BS 86 \\
\hline $\mathrm{H}^{+}\left(\mathrm{H}_{2} \mathrm{O}\right)_{2}+e^{-}$ & $\rightarrow$ & $\mathrm{H}+2 \mathrm{H}_{2} \mathrm{O}$ & $4.0(-6)$ & BS 86 \\
\hline $\mathrm{H}^{+}\left(\mathrm{H}_{2} \mathrm{O}\right)_{2}\left(\mathrm{~N}_{2}\right)+e^{-}$ & $\rightarrow$ & $\mathrm{H}+2 \mathrm{H}_{2} \mathrm{O}+\mathrm{N}_{2}$ & $4.0(-6)$ & BS 86 \\
\hline $\mathrm{H}^{+}\left(\mathrm{H}_{2} \mathrm{O}\right)\left(\mathrm{N}_{2}\right)+e^{-}$ & $\rightarrow$ & $\mathrm{H}+\mathrm{H}_{2} \mathrm{O}+\mathrm{N}_{2}$ & $4.0(-6)$ & BS 86 \\
\hline $\mathrm{H}^{+}\left(\mathrm{H}_{2} \mathrm{O}\right)\left(\mathrm{CO}_{2}\right)+e^{-}$ & $\rightarrow$ & $\mathrm{H}+\mathrm{H}_{2} \mathrm{O}+\mathrm{CO}_{2}$ & $4.0(-6)$ & BS 86 \\
\hline $\mathrm{H}^{+}\left(\mathrm{H}_{2} \mathrm{O}\right)_{2}\left(\mathrm{CO}_{2}\right)+e^{-}$ & $\rightarrow$ & $\mathrm{H}+2 \mathrm{H}_{2} \mathrm{O}+\mathrm{CO}_{2}$ & $4.0(-6)$ & BS 86 \\
\hline $\mathrm{CO}^{+}+e-$ & $\rightarrow$ & $\mathrm{CO}$ & $4.0(-6)$ & BS 86 \\
\hline $\mathrm{CO}_{2}^{+}+e^{-}$ & $\rightarrow$ & $\mathrm{CO}+\mathrm{O}$ & $4.0(-6)$ & BS 86 \\
\hline $\mathrm{H}^{+}\left(\mathrm{H}_{2} \mathrm{O}\right)_{3}+e^{-}$ & $\rightarrow$ & $\mathrm{H}+3 \mathrm{H}_{2} \mathrm{O}$ & $4.0(-6)$ & BS 86 \\
\hline $\mathrm{H}^{+}\left(\mathrm{H}_{2} \mathrm{O}\right)_{4}+e^{-}$ & $\rightarrow$ & $\mathrm{H}+4 \mathrm{H}_{2} \mathrm{O}$ & $4.0(-6)$ & BS 86 \\
\hline $\mathrm{H}^{+}\left(\mathrm{H}_{2} \mathrm{O}\right)_{5}+e^{-}$ & $\rightarrow$ & $\mathrm{H}+5 \mathrm{H}_{2} \mathrm{O}$ & $4.0(-6)$ & BS 86 \\
\hline $\mathrm{H}^{+}\left(\mathrm{H}_{2} \mathrm{O}\right)_{6}+e^{-}$ & $\rightarrow$ & $\mathrm{H}+6 \mathrm{H}_{2} \mathrm{O}$ & $4.0(-6)$ & BS 86 \\
\hline $\mathrm{H}^{+}\left(\mathrm{H}_{2} \mathrm{O}\right)_{7}+e^{-}$ & $\rightarrow$ & $\mathrm{H}+7 \mathrm{H}_{2} \mathrm{O}$ & $4.0(-6)$ & BS 86 \\
\hline $\mathrm{H}^{+}\left(\mathrm{CH}_{3} \mathrm{CN}\right)\left(\mathrm{H}_{2} \mathrm{O}\right)_{6}+e^{-}$ & $\rightarrow$ & $\mathrm{H}+\mathrm{CH}_{3} \mathrm{CN}+6 \mathrm{H}_{2} \mathrm{O}$ & $4.0(-6)$ & BS 86 \\
\hline $\mathrm{H}^{+}\left(\mathrm{CH}_{3} \mathrm{CN}\right)_{3}\left(\mathrm{H}_{2} \mathrm{O}\right)_{2}+e^{-}$ & $\rightarrow$ & $\mathrm{H}+3 \mathrm{CH}_{3} \mathrm{CN}+2 \mathrm{H}_{2} \mathrm{O}$ & $4.0(-6)$ & BS 86 \\
\hline $\mathrm{H}^{+}\left(\mathrm{CH}_{3} \mathrm{CN}\right)_{3}\left(\mathrm{H}_{2} \mathrm{O}\right)+e^{-}$ & $\rightarrow$ & $\mathrm{H}+3 \mathrm{CH}_{3} \mathrm{CN}+\mathrm{H}_{2} \mathrm{O}$ & $4.0(-6)$ & BS 86 \\
\hline $\mathrm{H}^{+}\left(\mathrm{CH}_{3} \mathrm{CN}\right)_{3}+e^{-}$ & $\rightarrow$ & $\mathrm{H}+3 \mathrm{CH}_{3} \mathrm{CN}$ & $4.0(-6)$ & BS 86 \\
\hline $\mathrm{H}^{+}\left(\mathrm{CH}_{3} \mathrm{CN}\right)_{2}\left(\mathrm{H}_{2} \mathrm{O}\right)_{4}+e^{-}$ & $\rightarrow$ & $\mathrm{H}+2 \mathrm{CH}_{3} \mathrm{CN}+4 \mathrm{H}_{2} \mathrm{O}$ & $4.0(-6)$ & BS 86 \\
\hline $\mathrm{H}^{+}\left(\mathrm{CH}_{3} \mathrm{CN}\right)_{2}\left(\mathrm{H}_{2} \mathrm{O}\right)_{3}+e^{-}$ & $\rightarrow$ & $\mathrm{H}+2 \mathrm{CH}_{3} \mathrm{CN}+3 \mathrm{H}_{2} \mathrm{O}$ & $4.0(-6)$ & BS 86 \\
\hline $\mathrm{H}^{+}\left(\mathrm{CH}_{3} \mathrm{CN}\right)_{2}\left(\mathrm{H}_{2} \mathrm{O}\right)_{2}+e^{-}$ & $\rightarrow$ & $\mathrm{H}+2 \mathrm{CH}_{3} \mathrm{CN}+2 \mathrm{H}_{2} \mathrm{O}$ & $4.0(-6)$ & BS 86 \\
\hline $\mathrm{H}^{+}\left(\mathrm{CH}_{3} \mathrm{CN}\right)_{2}\left(\mathrm{H}_{2} \mathrm{O}\right)+e^{-}$ & $\rightarrow$ & $\mathrm{H}+2 \mathrm{CH}_{3} \mathrm{CN}+\mathrm{H}_{2} \mathrm{O}$ & $4.0(-6)$ & BS 86 \\
\hline $\mathrm{H}^{+}\left(\mathrm{CH}_{3} \mathrm{CN}\right)_{2}+e^{-}$ & $\rightarrow$ & $\mathrm{H}+2 \mathrm{CH}_{3} \mathrm{CN}$ & $4.0(-6)$ & BS 86 \\
\hline
\end{tabular}

Abbreviations for references see footnote in Table 3

Table 11 Electron attachment and negative charge transfer of oxygen species, see also caption to Table 4

\begin{tabular}{lllll}
\hline Reactants & & Products & Rate coefficient $\left(\mathrm{cm}^{3(n-1)} \mathrm{s}^{-1}\right)$ & Refs. \\
\hline$e^{-}+\mathrm{O}_{2}$ & $\rightarrow$ & $\mathrm{X}^{-}$ & $1.0(-31) \cdot\left[\mathrm{N}_{2}\right]+4.0(-30) \cdot \mathrm{e}^{\frac{-193}{T}}\left[\mathrm{O}_{2}\right]$ & Kazil 02 \\
$e^{-}+\mathrm{O}_{3}$ & $\rightarrow$ & $\mathrm{X}^{-}$ & $9.1(-12)(300 / T)^{1.46}$ & Kazil 02 \\
$\mathrm{X}^{-}+\mathrm{O}$ & $\rightarrow$ & $e^{-}+\mathrm{O}$ & $1.0(-10)$ & Kazil 02
\end{tabular}

Abbreviations for references see footnote in Table 3 


\section{References}

Aikin AC (1997) Production of stratospheric $\mathrm{HNO}_{3}$ by different ion-molecule reaction mechanisms. J Geophys Res 102:12921-12925

Anchordoqui L, Paul T, Reucroft S, Swain J (2002) Ultrahigh energy cosmic rays: the state of the art before the Auger observatory. arxiv.org/abs/hep-ph/0206072v3

Andersson ME, Verronen PT, Wang S, Rodger CJ, Clilverd MA, Carson BR (2012) Precipitating radiation belt electrons and enhancements of mesospheric hydroxyl during 2004-2009. J Geophys Res 117. doi: 10.1029/2011JD017246

Anicich VG (1993) Evaluated bimolecular ion-molecule gas phase kinetics of positive ions for use in modeling planetary atmospheres, cometary comae, and interstellar clouds. J Phys Chem Ref Data 22. doi:10.1063/1.555940

Baker DN, Goldberg RA, Herrero FA, Blake JB, Callis LB (1993) Satellite and rocket studies of relativistic electrons and their influence on the middle atmosphere. J Atmos Terr Phys 55:1619-1628

Baldwin MP, Dunkerton TJ (1999) Propagation of the Arctic Oscillation from the stratosphere to the troposphere. J Geophys Res 104:30937-30946

Banks PM (1977) Observations of Joule and particle heating in the auroral zone. J Atm Terr Phys 39:179-193

Banks PM (1979) Joule heating in the high-latitude mesosphere. J Geophys Res 84:6709-6712

Banks PM, Kockarts G (1973) Aeronomy. Academic Press, New York

Barth CA (1992) Nitric oxide in the lower thermosphere. Planet Space Sci 40:315-336

Barth CA (2010) Joule heating and nitric oxide in the thermosphere. J Geophys Res 115:A10305

Barth CA, Bailey SM, Solomon SC (1999) Solar-terrestrial coupling: solar soft X-rays and thermospheric nitric oxide. Geophys Res Lett 26:1251-1254

Barth CA, Baker DN, Mankoff KD, Bailey SM (2001) The northern auroral region as observed in nitric oxide. Geophys Res Letters 28:1463-1466

Barth CA, Mankoff KD, Bailey SM, Solomon SC (2003) Global observations of nitric oxide in the thermosphere. J Geophys Res 108. doi: 10.1029/2002JA009458

Barth CA, Lu G, Roble RG (2009) Joule heating and nitric oxide in the thermosphere. J Geophys Res 114. doi: 10.1029/2008JA013765

Barth CA, Tobiska WK, Siskind DE, Cleary DD (1988) Solar terrestrial coupling: low-latitude thermospheric nitric oxide. Geophys Res Letters 15:92

Bates DR, Nicolet M (1950) The photochemistry of atmospheric water vapor. J Geophys Res 55:301-327

Baumgaertner AJG, Jöckel P, Brühl C (2009) Energetic particle precipitation in ECHAM5/MESSy1-part 1: downward transport of upper atmospheric NOx produced by low energy electrons. Atmos Chem Phys 9:2729-2740

Baumgaertner AJG, Jöckel P, Riede H, Stiller G, Funke B (2010) Energetic particle precipitation in ECHAM5/MESSy_part 2: solar proton events. Atmos Chem Phys 10. doi: 10.5194/acp-10-7285-2010

Baumgaertner AJG, Seppälä A, Jöckel P, Clilverd MA (2011) Geomagnetic activity related NOx enhancements and polar surface air temperature variability in a chemistry climate model: modulation of the NAM index. Atmos Chem Phys 11. doi: 10.5194/acp-11-4521-2011

Becker E, von Savigny C (2010) Dynamical heating of the polar summer mesopause induced by solar proton events. J Geophys Res 115. doi: 10.1029/2009JD012561

Berger U (2008) Modeling of middle atmosphere dynamics with LIMA. J Atmos Solar Terr Phys 70:1170-1200

Böhringer H, Fahey DW, Fehsenfeld FC, Ferguson E (1983) The role of ionmolecule reactions in the conversion of $\mathrm{N}_{2} \mathrm{O}_{5}$ to $\mathrm{HNO}_{3}$ in the stratosphere. Planet Space Sci 31:185-191

Brasseur G, Chatel A (1983) Modelling of stratospheric ions: a first attempt. Ann Geophys 1:173-185

Brasseur G, Nicolet M (1973) Chemospheric processes of nitric oxide in the mesosphere and stratosphere. Planet Space Sci 21:939-961

Brasseur G, Solomon S (1986) Aeronomy of the middle atmosphere: chemistry and physics of the stratosphere and mesosphere. D. Reidel, Dordrecht

Brown RR (1968) Auroral enhancement of atomic nitrogen. J Atmos Terr Phys 30:55-61

Callis LB, Natarajan M, Evans DS, Lambeth JD (1998a) Solar atmospheric coupling by electrons (SOLACE) 1. Effects of the May 12, 1997 solar event on the middle atmosphere. J Geophys Res 103:28405-28419

Callis LB, Natarajan M, Lambeth JD, Baker DN (1998b) Solar atmospheric coupling by electrons (SOLACE) 2. Calculated stratospheric effects of precipitating electrons, 1979-1988. J Geophys Res 103:28421-28438 
Callis LB, Natarajan M, Lambeth JD (2001) Solar-atmospheric coupling by electrons (SOLACE) 3. Comparisons of simulations and observations, 1979-1997, issues and implications. J Geophys Res 106:7523-7539

Cane HV, von Rosenvinge TT, Cohen CMS, Mewaldt RA (2003) Two components in major solar particle events. Geophys Res Lett 12. doi: 10.1029/2002GL016580

Chipperfield MP (1999) Multiannual simulations with a three-dimensional chemical transport model. J Geophys Res 104:1781-1805

Clilverd MA, Seppälä A, Rodger CJ, Thomson NR, Lichtenberger J, Steinbach P (2007) Temporal variability of the descent of high-altitude NOx inferred from ionospheric data. J Geophys Res 112. doi: 10.1029/2006JA012085

Clilverd MA, Seppälä A, Rodger CJ, Mlynczak MG, Kozyra JU (2009) Additional stratospheric NOx production by relativistic electron precipitation during the 2004 spring NOx descent. J Geophys Res 114. doi:10.1029/2008JA013472

Cravens TE, Stewart AI (1978) Global morphology of nitric oxide in the lower E region. J Geophys Res $83: 2446-2452$

Cravens TE, Gerard J-C, LeCompte M, Stewart AI, Rusch DW (1985) The global distribution of nitric oxide in the thermosphere as determined by the atmosphere explorer D satellite. J Geophys Res 90:9862-9870

Crowley G, Ridley A, Winningham D, Frahm R, Sharber J, Russell JM (1998) Nitric oxide variations in the mesosphere and lower thermosphere during the November 1993 storm period. J Geophys Res 103:26395-26407

Crutzen PJ (1970) The influence of nitrogen oxides on the atmospheric ozone content. Q J Roy Met Soc 96:320-325

Crutzen PJ (1975) Solar proton events: stratospheric sources of nitric oxide. Science 189:457-459

Crutzen PJ, Solomon S (1980) Response of mesospheric ozone to particle precipitation. Planet Space Sci 28:1147-1153

Damiani A, Storini M, Rafanelli C, Diego P (2010) The hydroxyl radical as an indicator of SEP fluxes in the high-latitude terrestrial atmosphere. Adv Space Res 46. doi: 10.1016/j.asr.2010.06.022

D'Angelo N, Ungstrup E (1976) On the occurrence of widely observed noctilucent clouds. J Geophys Res $81: 1777-1778$

de Sousa AR, Touzeau M, Petitdidier M (1985) Quenching reactions of metastable $\mathrm{N}_{2}\left(\mathrm{~A}^{3} \Sigma v=0,1,2\right)$ molecules by $\mathrm{O}_{2}$. Chem Phys Lett 121:423-428

de Zafra R, Smyshlyaev SP (2001) On the formation of $\mathrm{HNO}_{3}$ in the Antarctic mid to upper stratosphere in winter. J Geophys Res 106:23115-23125

Dobbin AL, Aylward AD (2008) A three-dimensional modelling study of the processes leading to mid latitude nitric oxide increases in the lower thermosphere following periods of high geomagnetic activity. Adv Space Res 42:1576-1585

Dobbin AL, Aylward AD, Harris MJ (2006) Three-dimensional GCM modeling of nitric oxide in the lower thermosphere. J Geophys Res 111. doi: 10.1029/2005JA011543

Fang X, Randall CE, Lummerzheim D, Solomon SC, Mills MJ, Marsh DR, Jackman CH, Wang W, Lu G (2008) Electron impact ionization: A new parameterisation for $100 \mathrm{eV}$ to $1 \mathrm{MeV}$ electrons. J Geophys Res 113. doi: 10.1029/2008JA013384

Fang X, Randall CE, Lummerzheim D, Wang W, Lu G, Solomon SC, Frahm RA (2010) Parameterization of monoenergetic electron impact ionization. Geophys Res Lett 37. doi: 10.1029/2010GL045406

Feofilov AG, Kutepov AA (2012) Infrared radiance in the mesosphere and lower thermosphere, this issue

Fesen C, Rusch D, Gerard J-C (1990) The latitudinal gradient of the NO peak density. J Geophys Res 95:19053-19059

Fritzenwallner J, Kopp E (1998) Model calculations of the negative ion chemistry in the mesosphere with special emphasis on the chlorine species and the formation of cluster ions. Adv Space Res 21:891-894

Funke B, Lopez-Puertas M, Gil-Lopez S, von Clarmann T, Stiller G, Fischer H, Kellmann S (2005) Downward transport of upper atmospheric NOx into the polar stratosphere and lower mesosphere during the Antarctic 2003 and Arctic 2002/2003 winters. J Geophys Res 110. doi: 10.1029/2005JD 006463

Funke B, López-Puertas M, Fischer H, Stiller GP, von Clarmann T, Wetzel G, Carli B, Belotti C (2007) Comment on 'origin of the January-April 2004 increase in stratospheric $\mathrm{NO}_{2}$ observed in northern polar latitudes' by J.-B. Renard et al. Geophys Res Lett 34:L07813. doi:10.1029/2006GL027518

Funke B, Garcia-Comas M, Lopez-Puertas M, Glatthor N, Stiller G, von Clarmann T, Semeniuk K, McConnell JC (2008a) Enhancement of $\mathrm{N}_{2} \mathrm{O}$ during the October-November 2003 solar proton events. Atmos Chem Phys 8:3805-3815 
Funke B, Lopez-Puertas M, Garcia-Comas M, Stiller G, von Clarmann T, Glatthor N (2008b) Mesospheric $\mathrm{N}_{2} \mathrm{O}$ enhancements as observed by MIPAS on Envisat during the polar winters in 2002-2004. Atmos Chem Phys 8:5787-5800

Funke B, Baumgaertner A, Calisto M, Egorova T, Jackman CH, Kieser J, Krivolutsky A, López-Puertas M, Marsh DR, Reddman T, Rozanov E, Salm S-M, Sinnhuber M, Stiller GP, Verronen PT, Versick S, von Clarmann T, Vyushkova TY, Wieters N, Wissing JM (2011) Composition changes after the "Halloween" solar proton event: the High-Energy Particle Precipitation in the Atmosphere (HEPPA) model versus MIPAS data intercomparison study. Atmos Chem Phys 11:9089-9139

Gerard J-C, Barth CA (1977) High-latitude nitric oxide in the lower thermosphere. J Geophys Res 82:674-680

Gopalswamy N (2008) Solar connections of geoeffective magnetic structures. J Atmos Solar Terr Phys 70:2078-2100

Grossmann KU, Frings WG, Offermann D, Andre L, Kopp E, Krankowsky D (1985) Concentrations of $\mathrm{H}_{2} \mathrm{O}$ and NO in the mesosphere and the lower thermosphere at high latitudes. J Atmos Terr Phys 47:291-300

Grygalashvyly M, Becker E, Sonnemann GR (2012) Gravity wave mixing and effective diffusivity for minor chemical constituents in the mesosphere/lower thermosphere. Space Sci Rev 168:333-362. doi: 10.1007/s11214-011-9857-X

Hauchecorne A, Bertaux J-L, Dalaudier F, Russell JM, Mlynczak MG, Kyrölä E, Fussen D (2007) Large increase of $\mathrm{NO}_{2}$ in the north polar mesosphere in January-February 2004: evidence of a dynamical origin from GOMOS/ENVISAT and SABER/TIMED data. Geophys Res Lett 34. doi: 10.1029/ 2006GL027628

Heath DF, Krueger AJ, Crutzen PJ (1977) Solar proton event: influence on stratospheric ozone. Science 197:886-889

Horne RB, Lam MM, Green JC (2009) Energetic electron precipitation from the outer radiation belt during geomagnetic storms. Geophys Res Lett 36. doi: 10.1029/2009GL040236

Iwagami N, Ogawa T (1980) An Antarctic NO density profile deduced from the gamma band airglow. Planet Space Sci 28:867-873

Jackman CH, Douglass AR, Rood RB, McPeters RD (1990) Effect of solar proton events on the middle atmosphere during the past two solar cycles as computed using a two-dimensional model. J Geophys Res 95:7417-7428

Jackman CH, Fleming EL, Vitt FM (2000) Influence of extremely large solar proton events in a changing stratosphere. J Geophys Res 105:11659-11670

Jackman CH, McPeters RD, Labow GJ, Fleming EL, Praderas CJ, Russell JM (2001) Northern Hemisphere atmospheric effects due to the July 2000 solar proton event. Geophys Res Lett 28:2883-2886

Jackman CH, DeLand MT, Labow GJ, Fleming EL, DK Weisenstein, Ko MK, Sinnhuber M, Russell JM (2005a) Neutral atmospheric influences of the solar proton events in October-November 2003. J Geophys Res 110. doi: 10.1029/2004JA010888

Jackman CH, DeLand MT, Labow GJ, Fleming EL, Weisenstein DK, Ko MK, Sinnhuber M, Anderson J, Russell JM (2005b) The influence of the several very large solar proton events in years 2000-2003 on the neutral middle atmosphere. Adv Space Res 35:445-450

Jackman CH, Roble RG, Fleming EL (2007) Mesospheric dynamical changes induced by the solar proton events in October-November 2003. Geophys Res Lett 34. doi: 10.1029/2006GL028328

Jackman CH, Marsh DR, Vitt FM, Garcia RR, Randall CE, Fleming EL, Frith SM (2009) Long-term middle atmospheric influence of very large solar proton events. J Geophys Res 114. doi: 10.1029/2008 JD011415

Jackman et al. CH (2011) Northern Hemisphere atmospheric influence of the solar proton events and ground level enhancement in January 2005. Atmos Chem Phys 11. doi: 10.5194/acp-11-6153-2011

Jones RA, Rees MH (1973) Time dependent studies of the aurora-I. Ion density and composition. Planet Space Sci 21:537-557

Kawa S, Kumer JB, Douglass AR, Roche AE, Smith SE, Taylor FW, Allen DJ (1995) Missing chemistry of reactive nitrogen in the upper stratospheric polar winter. Geophys Res Lett 22:2629-2632

Kazil J (2002) The University of Bern atmospheric ion model: Time-dependent ion modeling in the stratosphere, mesosphere and lower thermosphere, Dissertation, University of Bern (2002)

Kieffer LJ, Dunn GH (1966) Electron impact ionization cross-section data for atoms, atomic ions, and diatomic molecules: I. experimental data. Rev Mod Phys 38:1-35

Kodera K, Kuroda Y (2005) A possible mechanism of solar modulation of the spatial structure of the North Atlantic Oscillation. J Geophys Res 110. doi: 10.1029/2004JD005258

Kopp E (1996) Electron and ion densities. In: Dieminger W, Hartman GK, Leitinger R (eds) The upper atmosphere: data analysis and interpretation. Springer, Berlin, pp 620-630 
Kopp E, Fritzenwallner J (1997) Chlorine and bromine ions in the D-region. Adv Space Res 20:2111-2115

Kopp E, Andre L, Smith LG (1985) Positive ion composition and derived particle heating in the lower auroral ionosphere. J Atmos Terr Phys 47:301-308

Kosch MI, Yiu I, Anderson C, Tsuda T, Ogawa Y, Nozawa S, Aruliah A, Howells V, Baddeley LJ, McCrea IW, Wild JA (2011) Mesoscale observations of Joule heating near an auroral arc and ion-neutral collision frequency in the polar cap E-region. J Geophys Res 116. doi:10.1029/2010JA016015

Krivolutsky AA, Klyuchnikova AV, Zakharov GR, Vyushkova T, Kuminov AA (2006) Dynamical response of the middle atmosphere to solar proton event of July 2000: three-dimensional model simulations. Adv Space Res. 37. doi: 10.1016/j.asr.2005.05.115

Langematz U, Grenfell JL, Matthes K, Mieth P, Kunze M, Steil B, Brühl C (2005) Chemical effects in 11-year solar cycle simulations with the Freie Universität Berlin Climate Middle Atmosphere Model with online chemistry (FUB-CMAM-CHEM). Geophys Res Lett 32. doi: 10.1029/2005GL022686

Lary DJ (1997) Catalytic destruction of stratospheric ozone. J Geophys Res 102:21515-21526

Lee JN, Wu DL, Manney GL, Schwartz MJ (2009) Aura Microwave Limb Sounder observations of the Northern Annular Mode: from the mesosphere to the upper troposphere. Geophys Res Lett 36. doi: 10.1029/2009GL040678

Li Y, Jarvis MJ, Clilverd MA, Bates B (2011) Nonlinear and nonstationary influences of geomagnetic activity on the winter North Atlantic Oscillation. J Geophys Res 116. doi:10.1029/2011JD015822

Lopez-Puertas M, Funke B, Gil-Lopez S, von Clarmann T, Stiller G, Höpfner M, Kellmann S, Fischer H, Jackman CH (2005a) Observation of NOx enhancement and ozone depletion in the Northern and Southern Hemispheres after the October-November 2003 solar proton events. J Geophys Res 110. doi: 10.1029/2005JA011050

Lopez-Puertas M, Funke B, Gil-Lopez S, von Clarmann T, Stiller G, Höpfner M, Kellmann S, Tsidu GM, Fischer $\mathrm{H}$, Jackman $\mathrm{CH}(2005 \mathrm{~b}) \mathrm{HNO}_{3}, \mathrm{~N}_{2} \mathrm{O}_{5}$, and $\mathrm{ClONO}_{2}$ enhancements after the OctoberNovember 2003 solar proton events. J Geophys Res 110. doi: 10.1029/2005JA011051

Lopez-Puertas M, Funke B, von Clarmann T, Fischer H, Stiller G (2006) The stratospheric and mesospheric NOy in the 2002-2004 polar Winters as measured by MIPAS/ENVISAT. Space Sci Rev 125. doi: 10.1007/s11214-006-9073-2

Lu H, Clilverd MA, Seppälä A, Hood LL (2008a) Geomagnetic perturbations on stratospheric circulation in late winter and spring. J Geophys Res 113. doi: 10.1029/2007JD008915

Lu H, Jarvis MJ, Hibbins RE (2008b) Possible solar wind effect on the northern annular mode and northern hemispheric circulation during winter and spring. J Geophys Res 113. doi: 10.1029/2008JD010848

Lu G, Mlynczak MG, Hunt LA, Woods TN, Roble RG (2010) On the relationship of Joule heating and nitric oxide radiative cooling in the thermosphere. J Geophys Res 115. doi:10.1029/2009JA0146662

Majeed T, Strickland DJ (1997) New survey of electron impact cross sections for photoelectron and auroral electron energy loss calculations. J Phys Chem Ref Data 26:335-349

Marsh DR, Solomon SC, Reynolds AE (2004) Empirical model of nitric oxide in the lower thermosphere. J Geophys Res 109. doi:10.1029/2003JA010199

Marsh DR, Garcia RR, Kinnison DE, Boville BA, Sassi F, Solomon SC, Matthes K (2007) Modeling the whole atmosphere response to solar cycle changes in radiative and geomagnetic forcing. $\mathrm{J}$ Geophys Res 112. doi: 10.1029/2006JD008306

Matsuoka S, Nakamura $\mathrm{H}$, Tamura $\mathrm{T}$ (1981) Ion-molecule reactions of $\mathrm{N}_{3}^{+}, \mathrm{N}_{4}^{+}, \mathrm{O}_{2}^{+}$, and $\mathrm{NO}_{2}^{+}$in nitrogen containing traces of oxygen. J Chem Phys 75:681-690

Mayaud PN (1980) Derivation, meaning, and use of geomagnetic indices. In: Radiation belts: models and standards, geophysical monograph series, vol 22. American Geophysical Union, Washington

McPeters RD, Jackman CH (1985) The response of ozone to solar proton events during solar cycle 21: the observations. J Geophys Res 90:7945-7954

Millan RM, Thorne RM (2007) Review of radiation belt relativistic electron losses. J Atmos Solar Terr Phys 69:362-377

Mlynczak MG (1999) A new perspective on the molecular oxygen and hydroxyl airglow emissions. J Geophys Res 104:27535-27543

Mlynczak MG, Solomon S (1991) Middle atmosphere heating by exothermic chemical reactions involving odd-hydrogen species. Geophys Res Lett 18:37-40

Mlynczak MG, Solomon S (1993) A detailed evaluation of the heating efficiency in the middle atmosphere. J Geophys Res 98:10517-10541

Mlynczak MG, Hunt LA, Kozyra JU, Russell III JM (2010) Short-term periodic features ovserved in the infrared cooling of the thermosphere and in solar and geomagnetic indexes from 2002-2009. Proc Roy Soc A 466: 3409-3419. doi:10.1098/rspa.2010.0077

Mlynczak MG, Martin-Torres FJ, Crowley G, Kratz DP, Funke B, Lu G, Lopez-Puertas M, Russell III JM, Kozyra J, Mertens C, Sharma R, Gordley L, Picard R, Winick J, Paxton L (2005) Energy transport in 
the thermosphere during the solar storms of April 2002. J Geophys Res 110. doi:10.1029/ 2005JA011141

Mlynczak MG, Martin-Torres FJ, Mertens CJ, Marshall BT, Thompson RE, Kozyra JU, Remsberg EE, Gordley LL, Russell III JM, Woods T (2008) Solar-terrestrial coupling evidenced by periodic behavior in geomagnetic indixes and the infrared energy budget of the thermosphere. Geophys Res Lett 35. doi: 10.1029/2007GL032620

Newnham DA, Espy PJ, Clilverd MA, Rodger CJ, Seppälä A, Maxfield DJ, Hartogh P, Holmen K, Horne RB (2011) Direct observations of nitric oxide produced by energetic electron precipitation into the Antarctic middle atmosphere. Geophys Res Lett

Nicolet M (1965) Ionospheric processes and nitric oxide. J Geophys Res 70:691-701

Nicolet M (1975) On the production of nitric oxide by cosmic rays in the mesosphere and stratosphere. Planet Space Sci 23:637-649

Orsolini YJ, Manney GL, Santee ML, Randall CE (2005) An upper stratospheric layer of enhanced $\mathrm{HNO}_{3}$ following exceptional solar storms. Geophys Res Lett 32. doi: 10.1029/2004GL021588

Orsolini YJ, Urban J, Murtagh DP (2009) Nitric acid in the stratosphere based on Odin observations from 2001 to 2009-part 2: high-altitude polar enhancements. Atmos Chem Phys 9:7045-7052

Porter HS, Jackman CH, Green AES (1976) Efficiencies for production of atomic nitrogen and oxygen by relativistic proton impact in air. J Chem Phys 65:154-167

Prasad SS, Zipf EC (1981) Atmospheric nitrous oxide produced by solar protons and relativistic electrons. Nature 291:564-566

Prather M (1986) Numerical advection by conservation of second-order moments. J Geophys Res 91.doi: 10.1029/JD091iD06p06671

Price GD, Jacka F (1991) The influence of geomagnetic activity on the upper mesosphere/lower thermosphere in the auroral zone I: vertical winds. J Atmos Terr Phys 53(10):909-912

Price GD, Jacka F, Vincent RA, Burns GB (1991) The influence of geomagnetic activity on the upper mesosphere/lower thermosphere in the auroral zone. II. Horizontal winds. J Atmos Terr Phys 53:923-947

Qian L, Solomon SC, Mlynczak MG (2010) Model simulation of thermospheric response to recurrent geomagnetic forcing. J Geophys Res 115. doi. 10.1029/2010JA015309

Randall CE, Rusch DW, Bevilacqua RM, Hoppel KW, Lumpe JD (1998) Polar Ozone and Aerosol Measurement (POAM) II stratospheric NO2, 1993-1996. J Geophys Res 103:28361-28371

Randall CE, Siskind DE, Bevilacqua RM (2001) Stratospheric NOx enhancements in the southern hemisphere vortex in winter/spring of 2000. Geophys Res Lett 28:2385-2388

Randall et al. CE (2005) Stratospheric effects of energetic particle precipitation in 2003-2004. Geophys Res Lett 32. doi: 10.1029/2004GL022033

Randall CE, Harvey VL, Singleton CS, Bernath PF, Boone CD, Kozyra JU (2006) Enhanced NOx in 2006 linked to strong upper stratospheric Arctic vortex. Geophys Res Lett 33. doi: 10.1029/2006GL027160

Randall CE, Harvey VL, Singleton CS, Bailey SM, Bernath PF, Codrescu M, Nakajima H, Russell JM (2007) Energetic particle precipitation effects on the Southern Hemisphere stratosphere in 1992-2005. J Geophys Res 112. doi: 10.1029/2006JD007696

Randall CE, Harvey VL, Siskind DE, France J, Bernath PF, Boone CD, Walker KA (2009) NOx descent in the Arctic middle atmosphere in early 2009. Geophys Res Lett 36. doi: 10.1029/2009GL039706

Reames DV (1999) Particle acceleration at the sun and in the heliosphere. Space Sci Rev 90:413-491

Reddmann T, Ruhnke R, Versick S, Kouker W (2010) Modeling disturbed stratospheric chemistry during solar-induced NOx enhancements observed with MIPAS/ENVISAT. J Geophys Res 115. doi: 10.1029/2009JD012569

Rees MH (1989) Physics and chemistry of the upper atmosphere. Cambridge University Press, Cambridge

Rees MH, Emery BA, Roble RG, Stamnes K (1983) Neutral and ion gas heating by auroral electron precipitation. J Geophys Res 88:6289-6300

Renard J-B, Blelly P-L, Bourgeois Q, Chartier M, Goutail F, Orsolini YJ (2006) Origin of the January-April 2004 increase in stratospheric $\mathrm{NO}_{2}$ observed in the northern polar latitudes. Geophys Res Lett 33. doi: 10.1029/2005GL025450

Richards PG (2011) Reexamination of ionospheric photochemistry. J Geophys Res 116. doi: 10.1029/2011JA016613

Richardson IG, Cane HV (2010) Near-Earth interplanetary coronal mass ejections during solar cycle 23 (1996-2009): catalog and summary of properties. Sol Phys 264:189-237

Rinsland CP et al (1999) Polar stratosphericd escent of NOy and CO and Arctic denitrification during winter 1992-1993. J Geophys Res 104:1847-1861

Roble RG (1995) Energetics of the mesosphere and thermosphere. The upper mesosphere and lower thermosphere: a review of experiment and theory. Geophys Monogr 87:1-21 
Roble RG, Rees MH (1977) Time-dependent studies of the aurora: effects of particle precipitation on the dynamic morphology of ionospheric atmospheric properties. Planet Space Sci 25:991-1010

Roble RG, Ridley EC (1987) An auroral model for the NCAR thermospheric general circulation model (TGCM). Ann Geophys 5A:369-382

Roble RG, Forbes JM, Marcos FA (1987) Thermospheric dynamics during the March 22, 1979, magnetic storm 1. Model simulations. J Geophys Res 92:6045-6068

Rohen G, von Savigny C, Sinnhuber M, Llewellyn EJ, Kaiser JW, Jackman CH, Kallenrode M-B, Schröter J, Eichmann K-U, Bovensmann H, Burrows JP (2005) Ozone depletion during the solar proton events of Oct./Nov. 2003 as seen by SCIAMACHY. J Geophys Res110. doi:10.1029/2004JA010984

Rozanov E, Callis L, Schlesinger M, Yang F, Andronova N, Zubov V (2005) Atmospheric response to NOy source due to energetic electron precipitation. Geophys Res Lett 32. doi: 10.1029/2005GL023041

Rozanov E, Calisto M, Egorova T, Peter T, Schmutz W (2012) The influence of precipitating energetic particles on atmospheric chemistry and climate. Surv Geophys 33:483-501

Rusch DW, Barth CA (1975) Satellite measurements of nitric oxide in the polar region. J Geophys Res 80:3719-3721

Rusch DW, Gerard J-C, Solomon S, Crutzen PJ, Reid GC (1981) The effect of particle precipitation events on the neutral and ion chemistry of the middle atmosphere-I. Odd nitrogen. Planet Space Sci 29:767-774

Russell CT (2000) The solar wind interaction with the Earth's magnetosphere: a tutorial. IEEE Trans Plasma Sci 28:1818-1830

Russell JM, Solomon S, Gordley LL, Remsberg EE, Callis LB (1984) The variability of stratospheric and mesospheric $\mathrm{NO}_{2}$ in the polar winter night observed by LIMS. J Geophys Res 89:7267-7275

Saetre C, Stadsnes J, Nesse H, Aksnes A, Petrinec SM, Barth CA, Baker DN, Vondrak RR, Ostgaard N (2004) Energetic electron precipitation and the NO abundance in the upper atmosphere: a direct comparison during a geomagnetic storm. J Geophys Res 109, doi: 10.1029/2004JA010485

Salmi S-M, Verronen PT, Thölix L, Kyrölä E, Backman L, Karpechko AY, Seppälä A (2011) Mesosphereto-stratosphere descent of odd nitrogen in February-March 2009 after sudden stratospheric warming. Atmos Chem Phys11. doi: 10.5194/acp-11-4645-2011

Schmidt H, Brasseur GP, Charron M, Manzini E, Giorgetta MA, Diehl T, Fomichev VI, Kinnison D, Marsh D, Walters S (2006) The HAMMONIA chemistry climate model: sensitivity of the mesopause region to the 11-Year solar cycle and $\mathrm{CO}_{2}$ doubling. Am Met Soc 19:3903-3931

Schüssler et al. F (2010) Measurement of the energy spectrum of cosmic rays above $10^{18} \mathrm{eV}$ using the Pierre Auger Observatory. Phys Lett B 685. doi: 10.1016/j.physlteb.2010.02.013

Semeniuk K, McConnell JC, Jin JJ, Jarosz JR, Boone CD, Bernath PF (2008) $\mathrm{N}_{2} \mathrm{O}$ production by high energy auroral electron precipitation. J Geophys Res 113. doi: 10.1029/2007JD009690

Semeniuk K, Fomichev VI, McConnell JC, Fu C, Melo SML, Usoskin IG (2011) Middle atmosphere response to the solar cycle in irradiance and ionizing particle precipitation. Atmos Chem Phys 11:5045-5077

Seppälä A, Clilverd MA, Rodger CJ (2007a) NOx enhancements in the middle atmosphere during 2003-2004 polar winter: Relative significance of solar proton events and the aurora as a source. J Geophys Res 112. doi: 10.1029/2006JD008326

Seppälä A, Verronen PT, Clilverd MA, Randall CE, Tamminen J, Sofieva V, Backman L, Kyrölä E (2007b) Arctic and Antarctic polar winter NOx and energetic particle precipitation in 2002-2006. Geophys Res Lett 34. doi: 10.1029/2007GL029733

Seppälä A, Clilverd MA, Rodger CJ, Verronen PT, Turunen E (2008) The effects of hard-spectra solar proton events on the middle atmosphere. J Geophys Res 113. doi: 10.1029/2008JA013517

Seppälä A, Randall CE, Clilverd MA, Rozanov E, Rodger CJ (2009) Geomagnetic activity and polar surface air temperature variability. J Geophys Res 114. doi: 10.1029/2008JA014029

Sinnhuber M, Burrows J, Künzi KF, Chipperfield MP, Jackman CH, Kallenrode M-B, Quack M (2003) A model study of the impact of magnetic field structure on atmospheric composition during solar proton events. Geophys Res Lett 30. doi:10.1029/2006GL028106

Sinnhuber M, Jackman CH, Kallenrode M-B (2004) The impact of large Solar Proton Events on ozone in the polar stratosphere - a model study. In: Proceedings of the XX quadrennial ozone symposium, Ed. Ch. Zerefos, Kos

Sinnhuber B-M, von der Gathen P, Sinnhuber M, Rex M, König-Langlo G, Oltmans SJ (2006) Large decadal scale changes of polar ozone suggest solar influence. Atmos Chem Phys 1835-1841

Sinnhuber M, Kazeminejad S, Wissing J-M (2011) Interannual variation of NOx from the lower thermosphere to the upper stratosphere in the years 1991-2005. J Geophys Res 116. doi:10.1029/ 2010JA015825 
Sinnhuber M, Wieters N, Winkler H (2012) The impact of energetic particle precipitation on the chemical composition of the middle atmosphere: measurements and model predictions. In: Lübken F-J (ed) Climate and weather of the sun-earth system (Cawses): highlights from a priority program. Springer, Dordrecht. doi:10.1007/978-94-007-4348-9_16

Siskind DE, Russell JM (1996) Coupling between middle and upper atmospheric NO: constraints from HALOE observations. Geophys Res Lett 23:137-140

Siskind DE, Bacmeister JT, Summers ME, Russell JM (1997) Two-dimensional model calculations of nitric oxide transport in the middle atmosphere and comparison with Halogen Occultation Experiment data. J Geophys Res 102:3527-3545

Siskind DE, Barth CA, Russell JM (1998) A climatology of nitric oxide in the mesosphere and thermosphere. Adv Space Res 21:1353-1362

Siskind DE, Nedoluha GE, Russell JM, Randall CE, Fromm M (2000) An assessment of Southern Hemisphere stratospheric NOx enhancements due to transport from the upper atmosphere. Geophys Res Lett 27:329-332

Smith AK (2012) Global dynamics of the MLT, this issue. doi: 10.1007/s10712-012-9196-9

Solomon SC (2001) Auroral particle transport using Monte Carlo and hybrid methods. J Geophys Res 106. doi: 10.1029/2000JA002011

Solomon S, Rusch DW, Gerard J-C, Reid GC, Crutzen PJ (1981) The effect of particle precipitation events on the neutral and ion chemistry of the middle atmosphere: II. odd hydrogen. Planet Space Sci 29:885-892

Solomon S, Crutzen PJ, Roble RG (1982) Photochemical coupling between the thermosphere and the lower atmosphere 1. odd nitrogen from 50 to $120 \mathrm{~km}$. J Geophys Res 87:7206-7220

Solomon SC, Barth CA, Bailey SM (1999) Auroral production of nitric oxide measured by the SNOE satellite. Geophys Res Lett 26:1259-1262

Stiller G, Tsidu GM, von Clarmann T, Glatthor N, Höpfner M, Kellmann S, Linden A, Ruhnke R, Fischer H, Lopez-Puertas M, Funke B, Gil-Lopez S (2005) An enhanced $\mathrm{HNO}_{3}$ second maximum in the Antarctic midwinter upper stratosphere 2003. J Geophys Res 110. doi: 10.1029/2005JD006011

Storini M, Damiani A (2007) Effects of the January 2005 GLE/SPE events on minor atmospheric components. In: Proceedings of the international cosmic ray conference, Merida

Swider W, Keneshea TJ (1973) Decrease of ozone and atomic oxygen in the lower mesosphere during a PCA event. Planet Space Sci 21:1969-1973

Swider W, Keneshea TJ, Foley CI (1978) An SPE-disturbed D-region model. Planet Space Sci 26:883-892

Tsurutani BT, Gonzalez WD, Gonzalez ALC, Guarnieri FL, Gopalswamy N, Grande M, Kamide Y, Kasahara Y, Lu G, Mann I, McPherron R, Soraas F, Vasyliunas V (2006) Corotating solar wind streams and recurrent geomagnetic activity: a review. J Geophys Res 111. doi: 10.1029/2005JA011273

Turunen E, Matveinen H, Tolvanen J, Ranta H (1996) D-region ion chemistry model. In: Schunk RW (ed) STEP handbook of ionospheric models. SCOSTEP secretariat, Boulder, pp 1-25

Tyssoy HN, Stadsnes J, Sorbo M, Mertens CJ, Evans DS (2010) Changes in upper mesospheric and lower thermospheric temperatures caused by energetic particle precipitation. J Geophys Res 115. doi: 10.1029/2010JA015427

Usoskin IG, Kovaltsov GA, Mironova IA (2010) Cosmic ray induced ionization model CRAC:CRII: an extension to the upper atmosphere. J Geophys Res 115. doi:10.1029/2009JD013142

Verronen PT, Turunen E, Ulich T, Kyrölä E (2002) Modelling the effects of the October 1989 solar proton event on mesospheric odd nitrogen using a detailed ion and neutral chemistry model. Ann Geophys 20:1967-1976

Verronen PT, Funke B, Lopez-Puertas M, Stiller G, von Clarmann T, Glatthor N, Enell C-F, Turunen E, Tamminen $\mathrm{J}$ (2008) About the increase of $\mathrm{HNO}_{3}$ in the stratopause region during the Halloween 2003 solar proton event. Geophys Res Lett 35. doi: 10.1029/2008GL035312

Verronen PT, Rodger CJ, Clilverd MA, Wang S (2011a) First evidence of mesospheric hydroxyl response to electron precipitation from the radiation belts. J Geophys Res116. doi: 10.1029/2011JD014965

Verronen PT, Santee ML, Manney GL, Lehmann R, Salmi S, Seppälä A (2011b) Nitric acid enhancements in the mesosphere during the January 2005 and December 2006 solar proton events. J Geophys Res 116. doi: 10.1029/2011JD016075

Viggiano AA, Morris RA, van Doren JA, Paulsen JF (1992) Temperature, kinetic energy, and internal dependences of the rate constant and branching fraction for the reaction of $\mathrm{O}^{+}\left({ }^{4} \mathrm{~S}\right)$ with $\mathrm{CO}_{2}$. $\mathrm{J}$ Chem Phys 96. doi:10.1063/1.462514

Vitt FM, Jackman CH (1996) A comparison of sources of odd nitrogen production from 1974 through 1993 in the Earth's middle atmosphere as calculated using a two-dimensional model. J Geophys Res 101:6729-6739 
Vitt FM, Armstrong TP, Cravens TE, Dreschhoff GA, Jackman CH, Laird CM (2000a) Computed contributions to odd nitrogen concentrations in the Earth's polar middle atmosphere by energetic charged particles. J Atmos Solar Terr Phys 62:669-683

Vitt FM, Cravens TE, Jackman CH (2000b) A two-dimensional model of thermospheric nitric oxide sources and their contributions to the middle atmospheric chemical balance. J Atmos Solar Terr Phys 62:653-667

von Clarmann T, Glatthor N, Höpfner M, Kellmann S, Ruhnke R, Stiller G, Fischer H, Funke B, Gil-Lopez S, Lopez-Puertas M (2005) Experimental evidence of perturbed odd hydrogen and chlorine chemistry after the October 2003 solar proton events. J Geophys Res 110. doi: 10.1029/2005JA011053

von Savigny C, Sinnhuber M, Bovensmann H, Burrows JP, Kallenrode M-B, Schwartz M (2007) On the disappearance of noctilucent clouds during the January 2005 solar proton events. Geophys Res Lett 34. doi: $10.1029 / 2006 \mathrm{GL} 028106$

Weeks LH, CuiKay RS, Corbin RJ (1972) Ozone measurements in the mesosphere during the solar proton event of 2 November 1969. J Atmos Sci 29:1138-1142

Wilson GR, Weimar DR, Wise JO, Marcos FA (2006) Response of the thermosphere to Joule heating and particle precipitation. J Geophys Res 111. doi:10.1029/2005JA01127

Winkler H (2007) The response of middle atmospheric ozone to solar proton events in a changing geomagnetic field, Dissertation, University of Bremen

Winkler H, Sinnhuber M, Notholt J, Kallenrode M-B, Steinhilber F, Vogt J, Zieger B, Glassmeier K-H, Stadelmann A (2008) Modelling impacts of geomagnetic field variations on middle atmospheric ozone responses to solar proton events on long time scales. J Geophys Res 113. doi: 10.1029/2007JD008574

Winkler H, Kazeminejad S, Sinnhuber M, Kallenrode M-B, Notholt J (2009) Conversion of mesospheric $\mathrm{HCl}$ into active chlorine during the solar proton event in July 2000 in the northern polar region. J Geophys Res 114. doi: 10.1029/2008JD011587

Winkler H, Kazeminejad S, Sinnhuber M, Kallenrode M-B, Notholt J (2011) Correction to "Conversion of mesospheric $\mathrm{HCl}$ into active chlorine during the solar proton event in July 2000 in the northern polar region". J Geophys Res 116. doi:10.1029/2010JA015825

Wissing JM, Kallenrode M-B (2009) Atmospheric Ionization Module Osnabrück (AIMOS): a 3-D model to determine atmospheric ionization by energetic charged particles from different populations. J Geophys Res 114. doi: 10.1029/2008JA013884

Wissing JM, Kallenrode M-B, Wieters N, Winkler H, Sinnhuber M (2010) Atmospheric Ionization Module Osnabrück (AIMOS): 2. Total particle inventory in the October-November 2003 event and ozone. J Geophys Res 115. doi: 10.1029/2009JA014419

Zhang XX, Wang C, Chen T, Wang YL, Tan A, Wu TS Germany GA, Wang W (2005) Global patterns of Joule heating in the high-latitude ionosphere. J Geophys Res 110. doi: 10.1029/2005JA011222

Zhang J, Richardson IG, Webb DF, Gopalswamy N, Huttunen E, Kasper JC, Nitta NV, Poomvises W, Thompson BJ, Wu C-C, Yashiro S, Zhukov AN (2007) Solar and interplanetary sources of major geomagnetic storms (DST $\leq-100 \mathrm{nT}$ ) during 1996-2002. J Geophys Res 112. doi: 10.1029/2007JA 012321

Zipf EC (1980) A laboratory study of the formation of nitrous oxide by the reaction $\mathrm{N}_{2}\left(\mathrm{~A}^{3} \sum_{\mathrm{u}}{ }^{+}\right)+\mathrm{O}_{2} \rightarrow$ $\mathrm{N}_{2} \mathrm{O}+$ O. Nature 287. doi:10.1038/287523a0

Zipf EC, Prasad SS (1980) Production of nitrous oxide in the auroral D and E regions. Nature 287:525-526

Zipf EC, Borst WL, Donahue TM (1970) A mass spectrometer observation of NO in an auroral arc. J Geophys Res 75(31):6371-6376

Zipf EC, Espy PJ, Boyle CF (1980) The excitation and collisional deactivation of metastable $\mathrm{N}\left({ }^{2} \mathrm{P}\right)$ atoms in auroras. J Geophys Res 85:687-694 